DEPARTMENT OF THE INTERIOR

FrankLIN K. LANE, Secretary

UNited STATES GEOLOGICAL SURVEY

George Otis Smith, Director

Professional Paper 108-K

\title{
THE HELDERBERG LIMESTONE OF GENTRAL PENNSYLVANIA
}

BY

JOHN B. REESIDE, JR.

Published December 13, 1917

Shorter contributions to general geology, 1917

(Pages 185-225)

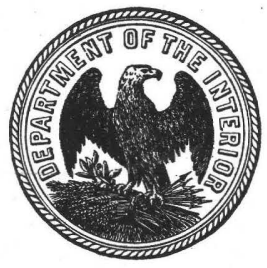

WASHINGTON

GOVERNMENT PRINTING OFFICE 


\section{CONTENTS.}

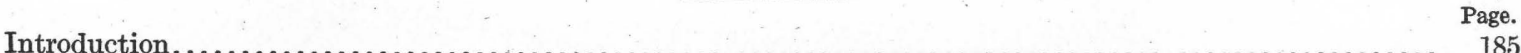

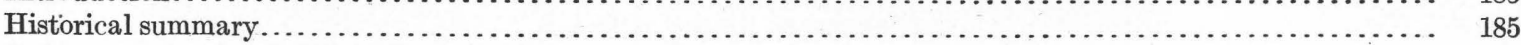

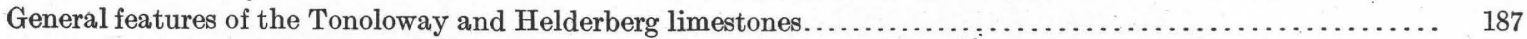

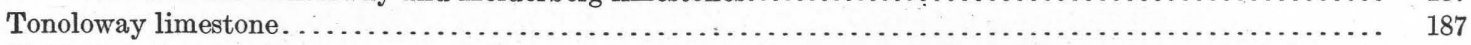

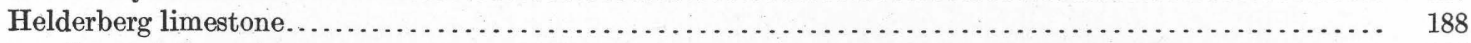

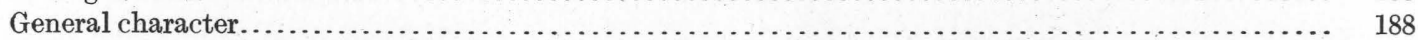

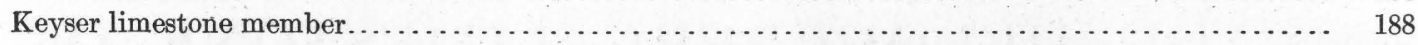

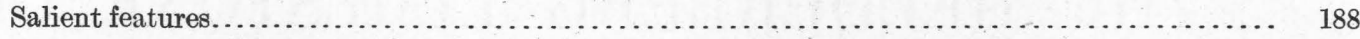

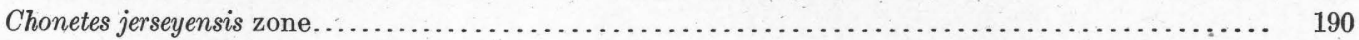

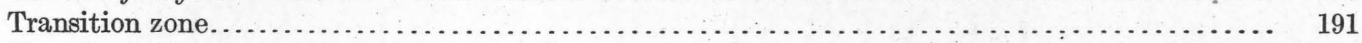

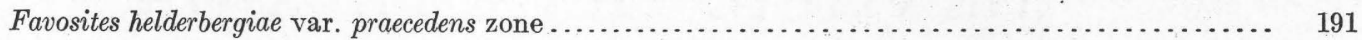

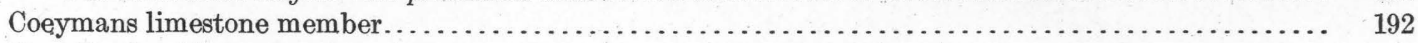

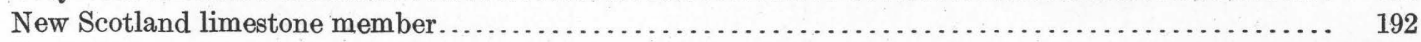

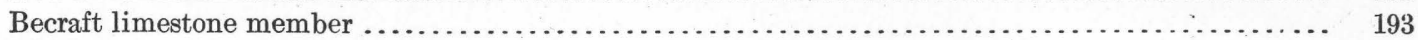

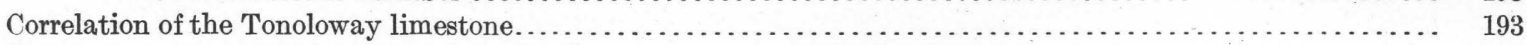

Correlation of the Helderberg limestone. . . . . . . . . . . . . . . . . . . . . . . . . . . . . . . .

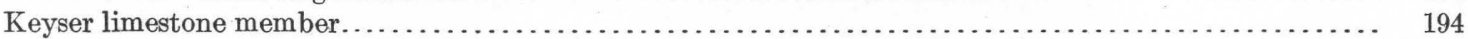

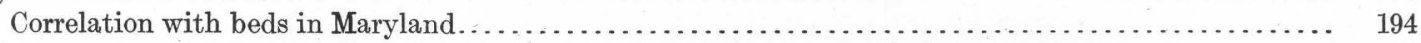

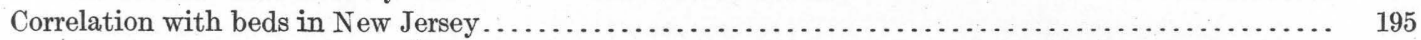

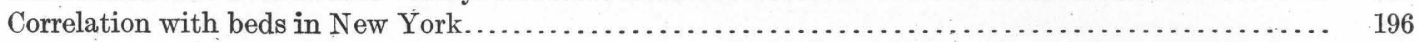

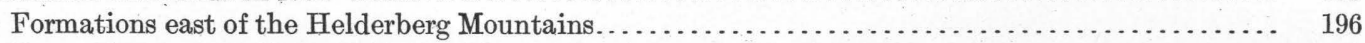

Formations west of the Helderberg Mountains. . . . . . . . . . . . . . . . . . . . . . . 196

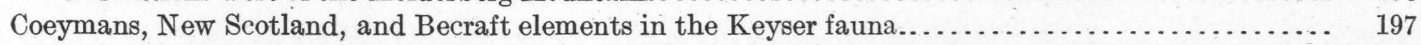

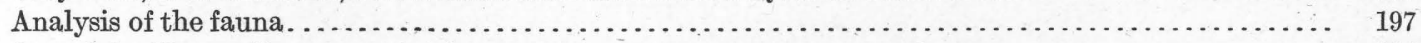

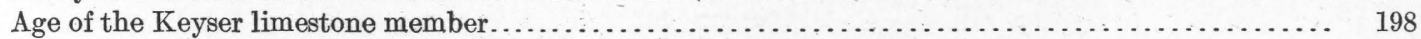

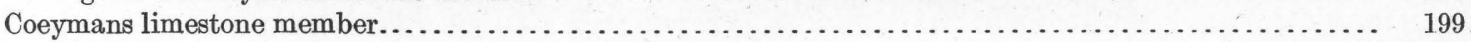

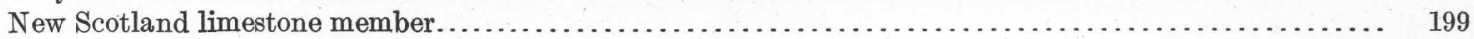

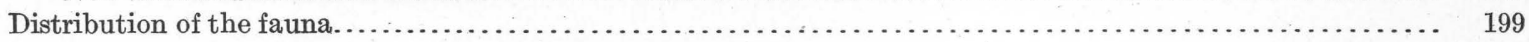

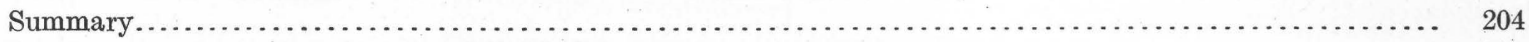

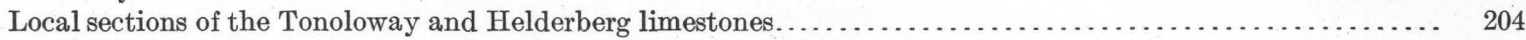

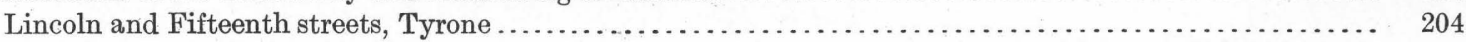

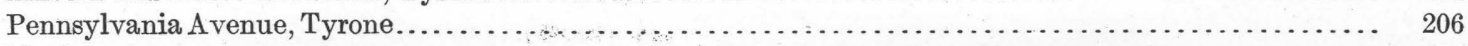

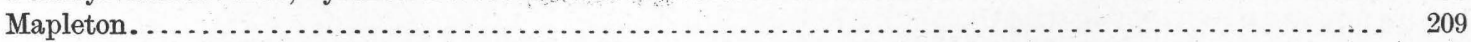

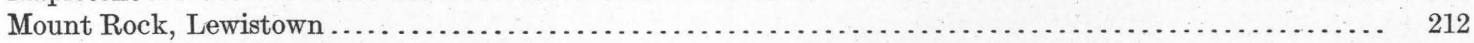

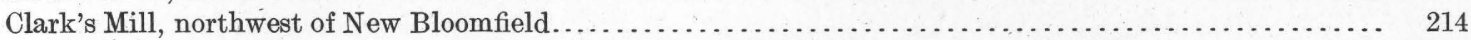

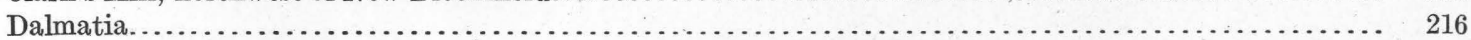

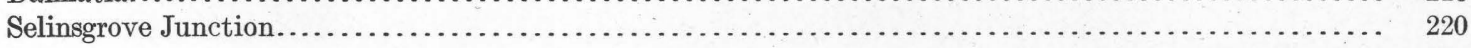

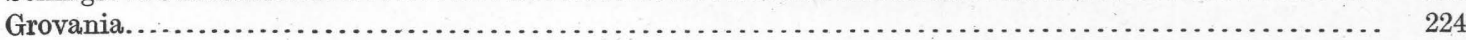

\section{ILLUSTRATIONS.}

Figure 28. Map showing outcrops of Helderberg limestone in Pennsylvania and Maryland............................

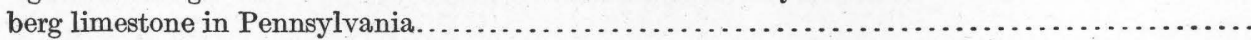

30. Diagram showing relations of the zones and subzones of the Keyser limestone member of the Helderberg limestone in Maryland. 


\title{
THE HELDERBERG LIMESTONE OF CENTRAL PENNSYLVANIA.
}

\author{
By John B. Reeside, Jr.
}

\section{INTRODUCTION.}

This paper presents the results of a study made during 1913,1914 , and 1915 , while the writer was a student at Johns Hopkins. University. The formations discussed have been studied in Maryland, New Jersey, and New York, and described with more or less detail, but concerning their occurrence in the intervening area in Pennsylvania little exact information has been available. The conflict in opinion as to the proper position and correlation of the Keyser limestone and as to the interpretation of some of the standard New York sections has made further data very desirable, and the present paper is an attempt to meet a part of the deficiency.

The writer wishes to express his indebtedness to the members of the geologic faculty of Johns Hopkins University, especially to Prof. W. B. Clark and Prof. G. K. Swartz, and for many helpful suggestions also to Mr. E. O. Ulrich, Mr. Charles Butts, and Mr. Arthur Keith, of the United States Geological Survey.

\section{HISTORICAL SUMMARY.}

The first systematic discussion of the rocks of Pennsylvania is contained in the first annual report of H. D. Rogers, as State geologist, to the Pennsylvania legislature, made in $1836 .{ }^{1}$ The present Helderberg limestone and an indeterminate thickness of late Silurian beds seem to be included in his division "No. 6," which is described "as "an argillaceous blue limestone" that "contains between its beds thin layers of shale resembling that last described (No. 5), though these grow less as we ascend, while the rock becomes progressively purer and less argillaceous." Rogers states

1 Rogers, H. D., Pennsylvania State Geologist First Ann. Rept., Harrisburg, 1836.

2 Idem, p. 14. also: "This stratum is terminated by layers of gray chert." In later reports Rogers used the Roman numeral (VI).

In 1843 Mather $^{3}$ correlated his Pentamerus limestone with Rogers's No. VI, and in the same year James Hall ${ }^{4}$ correlated the beds in the interval from the Niagara group to the "Upper Pentamerus" limestone inclusive with Rogers's No. VI.

In 1858 Rogers, in the long-delayed final report of the First Pennsylvania Survey, applied the so-called transcendental nomenclature to supplement the numerical designation of the preliminary reports. To No. V, the "Scalent series," he assigned three divisionsthe uppermost of which he described ${ }^{1}$ as

a blue flaggy limestone, sometimes containing bands of chert. Certain portions have thin-bedded, wavy stratification * * * This rock contains the Cytherina alta, Tentaculites ornatus, and a few other distinctive fossils.

No. VI, the "Pre-Meridian series," he described $^{1}$ as

a diversified calcareous formation, usually of some shade of grayish blue. It is argillaceous and flaggy in its lower beds and shaly toward the middle. It frequently contains layers and nodules of chert, especially near its upper limits. It has many characteristic fossils, the Pentamerus galeatus-and other shells, with corals.

Overlying these is the "Meridian slate," which apparently includes the shales at the top of the New Scotland and at the base of the Oriskany. Rogers correlated the limestone of his No. V with the "Waterlime" of New York, and his No. VI with the "Lower Helderberg" of New York: In discussing the rocks of the United States as a whole Rogers seems to transfer the "Meridian slate" and the "Scalent" limestone to the "Pre-Meridian

${ }^{3}$ Mather, W. W., Geology of New York, pt. 1 [First district], p. 325, 1843.

${ }^{4}$ Hall, James, Geology of New York, pt. 4 [Fourth district], pp. 80, 144, 145, 519, 1843.

5 Rogers, H. D., Geology of Pennsylvania, vol. 1, p. 107, 1858 
series." Hence in its larger aspect No. VI included the limestones of the late Silurian, the Helderberg, and the shales of the Oriskany.

In 1874 was established the Second Geological Survey of Pennsylvania, under J. P. Lesley. During the following 20 years this organization issued many county and special reports, in which the utmost freedom was allowed to the several geologists in the usage of stratigraphic names. The volumes therefore disagree among themselves. Very little detailed stratigraphio discussion is given in these reports. The following table shows the usage of the several geologists in describing the sections discussed in another part of this paper:
New York and its far more extensive and numerous lines of outcrop through Pennsylvania, it would be simply.misleading to describe it as composed of any fixed number of beds, or groups of beds, arranged in a definite series, each group characterized by one or more species of organic form. All that can be said of it with truth is this: (1), that it is mainly a limestone formation, underlying the whitish sandstone formation No. VII and overlying the reddish shale formation No. V; (2), that many of its beds are crowded with Pentamerus, Delthyris, Tentaculites, encrinal stems, and masses of coral; (3), that one or more of its beds are nearly solid layers of the sponge coral Stromatopora; (4), that at its bottom, whether included in it or not, are hydraulic limestone beds, containing the remains of lobsterlike creatures, Eurypterus and Polygnotus; and (5), that it might perhaps be made by a downward extension to include the whole Salina shale and Niagara limestone formations of western New York and Canada, were it not for the extraordinary thickness of the Salina red shales,

Usage of the Second Pennsylvania Geological Survey, correlated with stratigraphic divisions of the present paper.

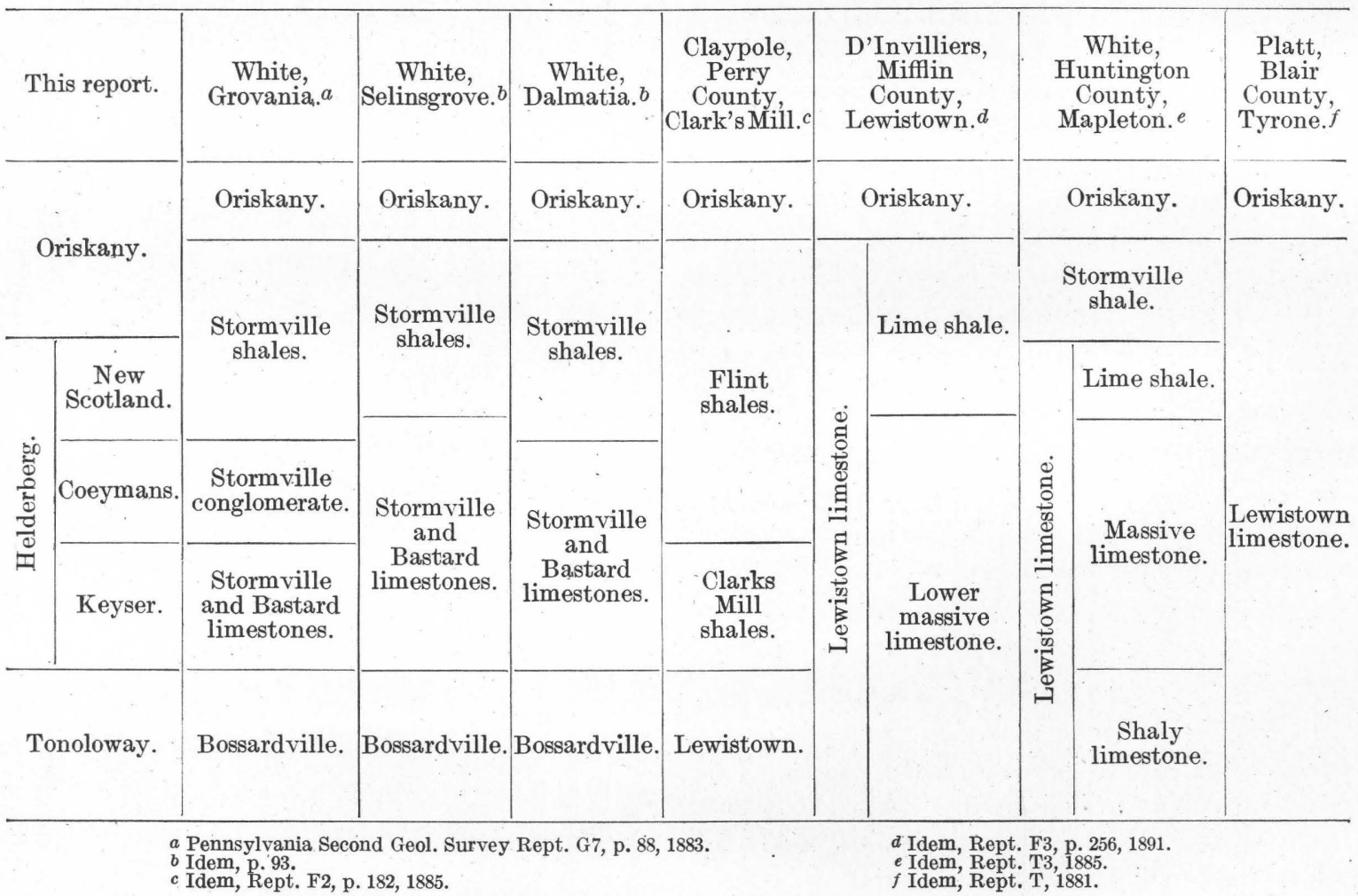

In 1892 Lesley $^{1}$ correlated No. VI in a general way with the "Lower Helderberg" (Helderberg) of New York, which he regarded as Silurian. His comment on this subject is characteristic:

Considering the great variety of thickness, quality, order of subdivision, and fossil distribution exhibited by the formation as a whole along its northern outcrop through

1 Lesley, J. P., Pennsylvania Second Geol. Survey Summary Final Rept., vol. 2, p. 904, 1892. especially in Pennsylvania, by which the Niagara is very far separated from the limestones of No. VI above.

In 1903 Schuchert ${ }^{2}$ stated that he had traced the Cobleskill and Manlius faunas through New Jersey, Pennsylvania, Maryland, and West Virginia, and that in central Pennsylvania these are still distinct, but that they become more confused in Maryland.

2 Schuchert, Charles, On the Manlius formation of New York: Am. Geologist, vol. 31, p. 176, 1903. 
In 1906 Grabau ${ }^{1}$ considered White's Stormville limestone of Pennsylvania to represent the Manlius and in part the Coeymans. The top of this limestone he believed to represent generally a marked break, indicated by conglomerate beds, composed at many places almost entirely of quartz. The section at Grovania, Pa., he cited as an example of overlap, the sandstone present being considered New Scotland and the underlying limestone Manlius and Decker.

In $1909 \mathrm{Grabau}^{2}$ expressed the view that the Lewistown represented only the upper part of his Monroan series - that is, the RosendaleManlius interval of New York.

In 1911 Ulrich $^{3}$ announced the presence of an unconformity of considerable time significance in certain beds of the Appalachian region previously referred to the upper Cayugan. The rocks between this horizon and another well up in the Coeymans of Schuchert and other authors he referred to as the Keyser limestone. For the Silurian beds beneath the Keyser limestone he used the name Tonoloway limestone. Ulrich did not discuss either unit in detail.

In 1912 Stose $^{4}$ gave an adequate description of the Tonoloway limestone and presented a statement (furnished by Ulrich) of the fauna and of its correlation. In this statement the beds just above the Tonoloway limestone were differentiated, as "the lowest faunal zone of the Helderberg," from the beds containing the Coeymans, New Scotland, and Becraft faunas.

In 1913 Grabau ${ }^{5}$ suggested the occurrence of the Bertie limestone at Selinsgrove Junction, $\mathrm{Pa}$., and again referred the entire Lewistown to his upper Monroan, disputing the reference of the Keyser and equivalent beds to the Devonian.

In 1913 also Brown, ${ }^{6}$ on paleontologic evidence, considered the Decker and Rondout present in Milesburg Gap, near Bellefonte, Pa.

1 Grabau, A. W., Guide to the geology and paleontology of the Schoharie Valley in eastern New York: New York State Mus. Bull. 92, p. 173, 1906.

2 Grabau, A. W., Physical and faunal evolution of North America during Ordovicic, Siluric, and early Devonic time: Jour. Geology, vol. 17 , p. 247,1909

3 Ulrich, E. O., Revision of the Paleozoic systems: Geol. Soc. America Bull., vol. 22, p. 590, 1911.

1 Stose, G. W., U. S. Geol. Survey Geol. Atlas, Pawpaw-Hancock folio (No. 179), p. 7, 1912.

5 Grabau, A. W., Early Paleozoic delta deposits of North America: Geol. Soc. America Bull., vol. 24, p. 510, 1913.

${ }^{6}$ Brown, T. C., Notes on the Siurian limestone of Milesburg Gap, near Bellefonte, Pa.: Am. Jour. Sci., 4th ser., vol. 35, p. 83, 1913.
In the same year the Maryland Geological Survey, ${ }^{7}$ in its volume on the Lower Devonian of Maryland, divided the Helderberg into the Keyser, Coeymans, New Scotland, and Becraft members, named in ascending order. The last three were correlated with the divisions of the same names in Pennsylvania and other States, and the Keyser with beds in sections at Clark's mill, Selinsgrove Junction, and Grovania, Pa., which are discussed in some detail. Regarding the State as a whole, the suggestion was made that the top of the Keyser is a plane of unconformity.

Schuchert ${ }^{8}$ in 1916 gave a brief discussion of the section in the Tyrone region. $\mathrm{He}$ attributed all the beds referable to the Helderbergian to the Keyser limestone, and expressed the opinion that there is a marked stratigraphic break at the top of the Keyser and possibly another at the base.

As this brief summary indicates, the amount of detailed information available concerning the Lower Devonian and late Silurian horizons of Pennsylvania leaves much to be desired. The present study of seven selected localities, it is hoped, will contribute toward the solution of some of the problems involved, though the writer recognizes fully the difficulties and limitations imposed upon correlations which are made without field work throughout the areas between the exposures discussed and which are based entirely upon the fossils collected.

\section{GENERAL FEATURES OF THE TONOLOWAY AND HELDERBERG LIMESTONES.}

\section{TONOLOWAY LIMESTONE.}

The type exposures of the Tonoloway limestone are in the lower slopes of Tonoloway Ridge, and the type locality is just west of Rock Ford, W. Va., where Great Cacapon River cuts through the ridge. The name was given by Ulirich, as stated above, but the formation was first adequately described by Stose. ${ }^{4}$ Typically it is composed of finely laminated light-gray limestone and calcareous shale and is generally more shaly toward the top.

${ }^{7}$ Maryland Geol. Survey, Lower Devonian, 1913.

8 Schuchert, Charles, Silurian formations of southeastern New. York, New Jersey, and Pennsylvania: Geol. Soc. America Bull., vol. 27, p. $552,1916$. 
The Tonoloway formation in central Pennsylvania has, at all the exposures studied except Tyrone, the same characteristic lithology, consisting of platy, in places laminated fine-grained gray limestones and calcareous shales. The uppermost beds in the Susquehanna region are heavy, pure, and very dark. At Tyrone the strata referred to the Tonoloway are relatively light cream-colored to buff limestones, in places platy and in places containing shale. These beds probably. represent a special facies very much like the Wills Creek shale of Maryland. Indeed, if there were sufficient evidence of an unconformity and hiatus at the top, the lithology of these beds would suggest their correlation with the Wills Creek. The Tonoloway at Tyrone also contains a bed of material that seems to be siliceous oolite.

The Tonoloway is not fully exposed at any of the localities studied. The maximum thickness observed is 325 feet.

The fauna of the Tonoloway in Pennsylvania as displayed in the sections studied comprises Camarotoechia? lamellata, Camarotoechia litchfieldensis, Spirifer keyserensis, Rhynchospira globosa var., Favosites sp. and other corals, Ectomaria minuta, Orthoceras sp., Leperditia sp., and other Ostracoda, Pelecypoda. Spirifer keyserensis occurs in the thick upper beds at Lewistown and near Dalmatia. It also occurs at about the same horizon in the Maryland Tonoloway. Associated with it are the two species of Camarotoechia. At Mapleton there is a bed about 40 feet below the top of the Tonoloway which is very fossiliferous. This bed carries Camarotoechia litchfieldensis, Spirorbis laxus?, Proetus sp.?, corals, Bryozoa, Pelecypoda, and abundant Leperditia. Below this is a bed with many poorly preserved brachiopods, almost all a species of Rhynchospira. Usually, however, the Tonoloway contains nothing but ostracodes, and in some places, as at Tyrone, even these are very rare. All the forms mentioned above occur also in the Maryland Tonoloway.

The Tonoloway and Keyser succession has been considered by most observers as uninterrupted, but Ulrich believes the two limestones to be separated by a marked break. The change from the platy fissile gray limestone of the Tonoloway to the much thickerbedded nodular bluish limestone of the Keyser, in some places very dark in color, is usually sharp. Even where the uppermost Tonoloway is massive, the nodular structure of the Keyser permits a separation.

HELDERBERG LIMESTONE.

GENERAL CHARACTER.

The Helderberg formation is a series of calcareous deposits of varied character. It includes some shale but is chiefly limestone. In lithology individual beds may represent any stage in the gradation between a coarse agglomeration of fossil fragments and a dense, very fine grained subcrystalline rock, or between a somewhat calcareous shale and a laminated impure limestone. Some parts of the formation have in all exposures much bedded chert, and locally chert is present as nodules in other parts of the formation. In very minor quantity arenaceous limestone and even calcareous sandstone are present.

Figure 28 shows the surface distribution of the Helderberg limestone in Maryland and Pennsylvania.

Four members are recognized in the Helderberg limestone-the Keyser limestone at the base, and above it, in order, the Coeymans limestone, the New Scotland limestone, and the Becraft limestone.

\section{KEYSER LIMESTONE MEMBER.}

\section{SALIENT FEATURES.}

The name Keyser limestone was first used by Ulrich, ${ }^{1}$ who oited Keyser, W. Va., as the source. He made several brief references as to its age and structural relation to the inclosing beds, but gave no adequate discussion. The first detailed account of the Keyser is to be found in the Lower Devonian volume of the Maryland Geological Survey cited above. This discussion is considered under the heading "Correlation of the Helderberg limestone". (pp. 194-199.) The Keyser limestone forms the larger part of the Helderberg of central Pennsylvania. It is divisible into two major lithologic units-a lower limestone series with many nodular layers and an upper series of relatively shaly limestone, which contains very few nodular beds. At Tyrone no nodular limestone whatever was recognized, but everywhere else it is a prominent feature. At Mapleton and near

1 Ulrich, E. O., Revision of the Paleozoic systems: Geol. Soc. America Bull., vol. 22, pl. 28, 1911. 
Lewistown a thick bed of very pure massive Dalmatia a distinct transitional unit lies crinoidal limestone lies near the base of the between them, and at Selinsgrove Junction and member. Here and there the Keyser contains Clark's Mill the faunas mingle somewhat near chert and in many places Stromatopora-bearing the limits of the two zones.

beds.

The Chonetes jerseyensis zone and the

The thickness is variable in the area studied, ranging from 88 feet in one of the Tyrone sections to 202 feet at Selinsgrove Junction.

Favosites helderbergiae var. praecedens zone may be divided into the following subzones, each with its diagnostic faunule:

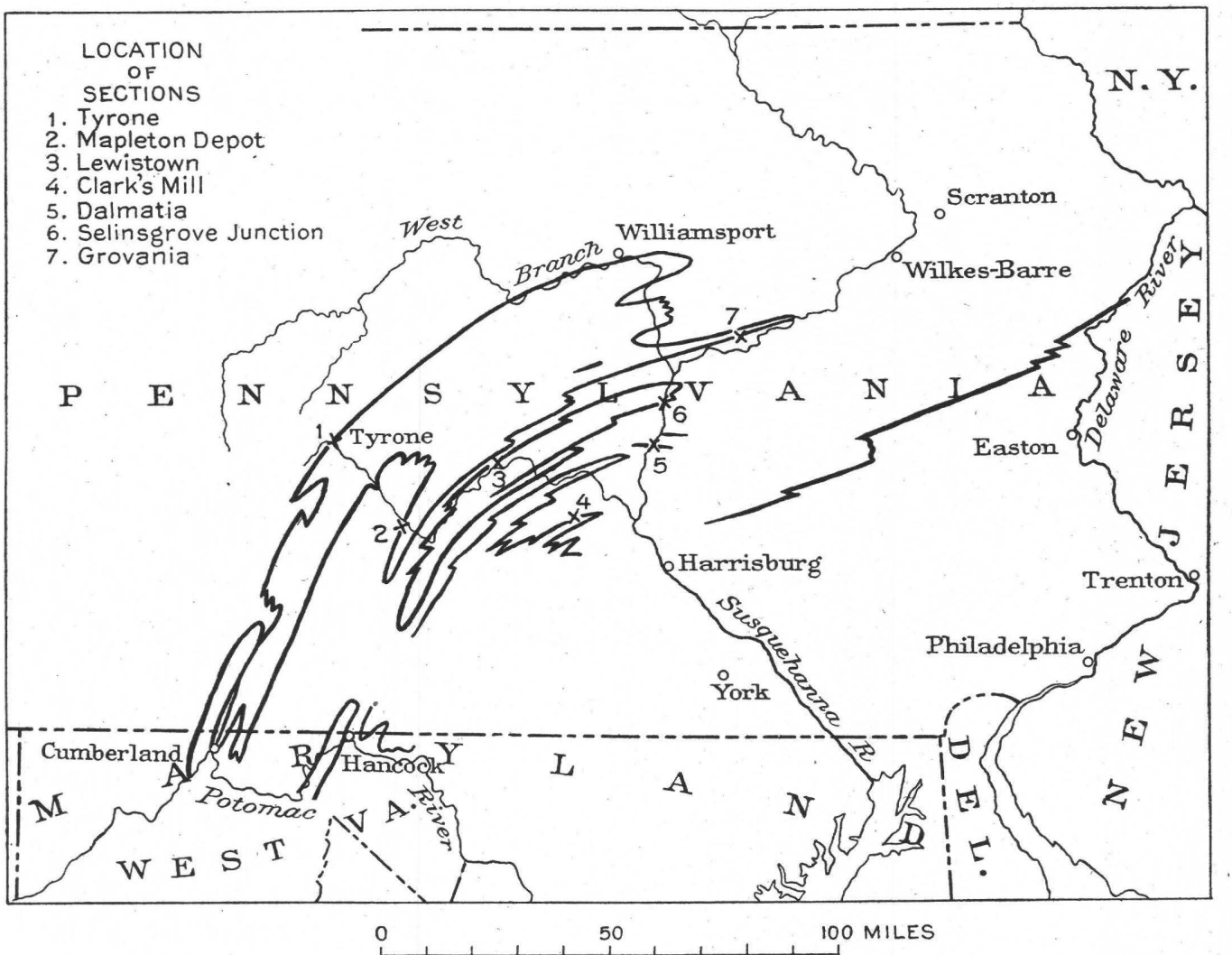

FIGURE 28.-Map showing outcrops of Helderberg limestone in Pennsylvania and Maryland.

Two major faunal units were recognized in the Keyser of Maryland, and were designated the Chonetes jerseyensis zone and the Favosites helderbergiae var. praecedens zone. ${ }^{1}$ As corresponding faunal units are present in the Keyser of Pennsylvania and agree in every essential with those found in Maryland, the same names will be used. The farositoid corals have not been studied in detail, but Favosites helderbergiae var. praecedens is known to occur in the Favosites zone in Pennsylvania. The faunal zones do not coincide with the two lithologic units described above. These faunal zones are sharply separated in some of the sections, but at Lewistown and south of

${ }^{1}$ Swartz, C. K., Maryland Geol. Survey, Lower Devonian, p. 99, 1913. $103969^{\circ}-17-2$
Favosites helderbergiae var. praecedens zone:

17. Upper Leperditia subzone.

16. Tentaculites subzone.

15. Stromatopora subzone B.

14. Rensselaeria mutabilis subzone.

13. Pholidops ovata subzone.

12. Lower Leperditia subzone.

11. Coral subzone B.

10. Spirifer vanuxemi var. prognosticus subzone.

Chonetes jerseyensis zone:

9. Calymene camerata subzone.

8. Bryozoan subzone.

7. Gypidula subzone.

6. Dalmanella clarki subzone.

5. Spirifer modestus subzone.

4. Stromatopora subzone A.

3. Coral subzone A.

2. Rhynchospira subzone

1. Camarotoechia? lamellata subzone. 
Figure 29 shows the relations of the faunal zones and subzones in the several sections and brings out the similarity of the faunal sequence at most of the localities studied. The sections at Grovania and Tyrone resemble one another and differ from those farther south and east, respectively. This fact suggests that some fundamental factor governing the deposition of the Keyser had its effect in a line nearly parallel to the present strike; possibly the amount of muddy sediment derived from the land mass to the east permitted greater coralline growth away from its shore. fer modestus, Stenoschisma formosa, Schuchertella deckerensis, and locally Orthostrophia strophomenoides, Dalmanella clarki, Sphaerocystites multifasciatus, Tentaculites gyracanthus, Calymene camerata, Proetus protuberans, and Proetus pachydermatus.

Coral subzone A.-At Tyrone the Rhynchospira subzone is overlain by beds containing a profusion of Cladopora rectilineata and Halysites catenulatus. Associated with them are Strophonella leavenworthana var., Spirifer octocostatus, Atrypa reticularis, and Rhynchospira globosa var.

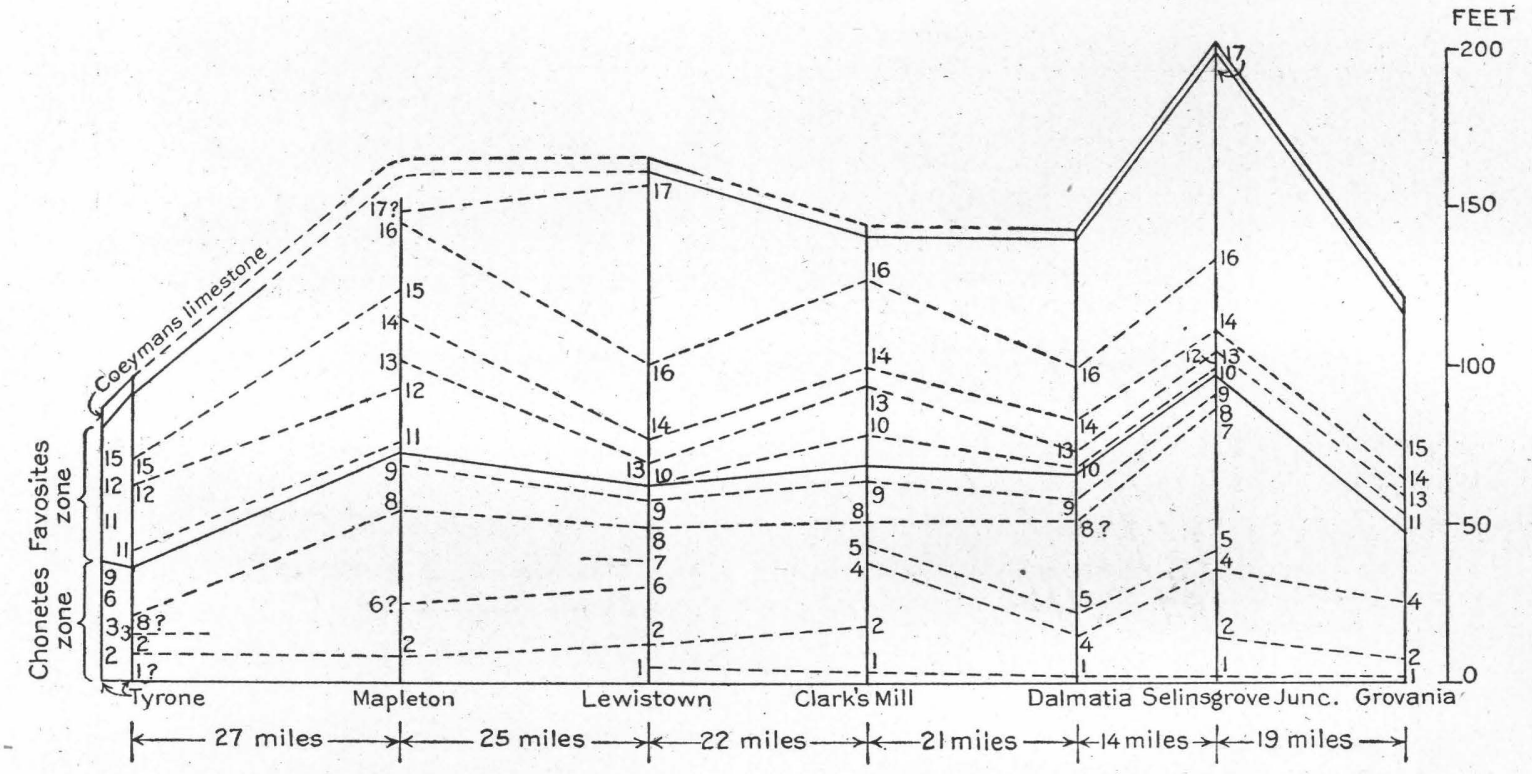

FIGURE 29.-Diagram showing relations of the zones and subzones of the Keyser limestone member of the Helderberg limestone in Pennsylvania.

CHONETES JERSEYENSIS ZONE.

Camarotoechia? lamellata subzone.-Camarotoechia? lamellata characterizes a subzone at the base of nearly all the sections. It is especially well shown at Dalmatia and Selinsgrove. Leperditia sp., Spirifer vanuxemi, and Rhynchospira globosa var. commonly occur in the subzone; Tentaculites gyracanthus, Photidops ovata, Spirifer modestus, Orthostrophia strophomenoides, and Stenoschisma formosa are less abundant.

Rhynchospira globosa var. subzone.-Above the Camarotoechia? lamellata subzone a variety of Rhynchospira globosa is abundant. Associated with it are Atrypa reticularis, Chonetes jerseyensis, Camarotoechia litchfieldensis, Leptaena rhomboidalis, Spirifer octocostatus, Spiri-
Stromatopora subzone A.-At Selinsgrove Junction a 6-foot bed of stromatoporoids lies about 20 feet above the Rhynchospira subzone. This bed is represented at Grovania by scattered heads of stromatoporoids, at Dalmatia by a 6-inch layer of stromatoporoids, and at Clark's Mill by a unit that bears loose on the surface numerous stromatoporoid fragments. The stratigraphic position of these occurrences is so nearly alike as to warrant the assumption that they are at the same horizon.

Spirifer modestus subzone.-Above the Stromatopora subzone $\mathbf{A}$ at Selinsgrove, Dalmatia, and Clark's Mill a definite horizon is marked by an abundance of Spirifer modestus, associated with which are Camarotoechia litchfieldensis, Chonetes jerseyensis, Rhynchospira for- 
mosa, Schuchertella deckerensis, Stenoschisma formosa, Stenoschisma deckerensis, Calymene camerata, and undetermined corals and ostracodes.

Dalmanella clarki subzone.-At Tyrone, Mapleton, and Lewistown Dalmanella clarki occurs between the Rhynchospira subzone and the Gypidula subzone and seems to characterize a definite horizon. The associated forms are very numerous and include most of the characteristic species of the Chonetes jerseyensis zone.

Gypidula coeymanensis var. prognostica subzone.-At Lewistown and Selinsgrove Junction Gypidula coeymanesis var. prognostica is abundant in a very massive nodular limestone. The form was not observed at any other horizon nor at any other locality. The associated species are Atrypa reticularis, Chonetes jerseyensis, Dalmanella concinna, Merista typa, Leptaena rhomboidalis, Orthostrophia strophomenoides, Schuchertella deckerensis, Spirifer octocostatus, Stenoschisma deckerensis, Stenoschisma formosa, Proetus protuberans.

Bryozoan subzone.-Above the Gypidula subzone at Lewistown and at a corresponding horizon at Mapleton, Dalmatia, and Clark's Mill there is a profusion of unstudied Bryozoa. At Tyrone and Selinsgrove a similar Bryozoan zone seems to be present, though not conspicuous. The forms associated with the Bryozoa include many of the characteristic species of the Chonetes jerseyensis zone.

Calymene camerata subzone.-Calymene camerata occurs above the Bryozoan subzone in nearly all the sections. In several sections this is the only occurrence, and in those in which the fossil occurs at several horizons it is the highest one. The associated forms are commonly Atrypa reticularis, Stropheodonta bipartita, Merista typa, Dalmanella concinna, Leptaena rhomboidalis, and less abundantly Schuchertella deckerensis, Camarotoechia litchfieldensis, Rensselaeria mutabilis, Spirifer vanuxemi var. prognosticus, and Uncinulus keyserensis.

\section{TRANSITION ZONE.}

At Lewistown and Dalmatia and to a less marked degree at Selinsgrove Junction and Clark's Mill Rensselaeria mutabilis, Beachia proavita, and Uncinulus keyserensis-forms which are usually confined to the Favosites zone-and Spirifer vanuxemi prognosticus and Pholidops ovata-forms which are abundant only in the Favosites zone-are associated with or beneath species which are confined at most localities to the Chonetes jerseyensis zone-that is, Dalmanella concinna, Leptaena rhomboidalis, Stropheodonta bipartita, Strophonella geniculata, Camarotoechia litchfieldensis, Atrypa reticularis, Merista typa, and Calymene camerata.

This transition zone varies in vertical thickness and in the number of subzones included in it in the four sections mentioned.

\section{FAVOSITES HELDERBERGIAE VAR. PRAECEDENS ZONE.}

The beds above the Calymene camerata subzone carry a fauna that is rather sharply separated from that of the Chonetes zone. The few forms which are common to both zones differ much in relative abundance. Such forms as Pholidops ovata, Spirifer vanuxemi var. prognosticus, and Tentaculites gyracanthus are unimportant members of the lower fauna, but they are abundant in the upper fauna. The complete absence of Atrypa reticularis and Leptaena rhomboidalis from the upper zone and their abundance in the underlying zone and the overlying Coeymans member is noteworthy. The presence of a transitional zone between the Favosites and Chonetes zones in some of the sections modifies the sharpness of the separation of the two faunas, but in general the statements made above hold good.

There are eight subzones in the Favosites zone.

Spirifer vanuxemi var. prognosticus subzone.-Just above the Calymene camerata subzone in several of the sections an abundance of Spirifer vanuxemi var. prognosticus marks apparently the same horizon.

Coral subzone B.-In the Grovania and Tyrone sections a thick bed of massive limestone is composed of a profusion of Cladopora rectilineata, Halysites catenulatus, Favosites sp., and other corals. Associated with these are scattered heads of Stromatopora, Bryozoa, and very rarely brachiopods of the genera Rhynchospira and Camarotoechia. At the top of this subzone is a bed of Stromatopora which might well be separated as a distinct subzone. At Mapleton this coral horizon is represented by a sparse occurrence of Cladopora rectilineata, Favosites, and other corals. 
Lower Leperditia subzone.-Above the coral subzone B at Tyrone and Mapleton there is an abundance of large Leperditias. These are associated at Mapleton with Uncinulus nucleolatus and Spirifer vanuxemi prognosticus. At Selinsgrove Junction a zone with Leperditia was observed which seems to be identical with that occurring farther west.

Pholidops ovata subzone.-Pholidops ovata occurs above the lower Leperditia subzone at Mapleton and Selinsgrove Junction and at a corresponding horizon in all the sections except at Tyrone. The associated forms are numerous and include species usually diagnostic of both Favosites and Chonetes zones.

Rensselaeria mutabilis subzone.-One of the most persistent subzones of the Pennsylvania sections is that marked by Rensselaeria mutabilis. In some of the sections this subzone contains the only specimens of this form, in others it is the horizon of greatest abundance. The associated species are the characteristic forms of the Favosites zone-Spirifer vanuxemi prognosticus, Uncinulus nucleolatus, Meristella praenuntia, and others.

Mapleton Stromatopora subzone.-At Mapleton the beds carrying the greatest abundance of Stromatopora are well up in the section and correspond to the upper Stromatopora beds at Grovania and Tyrone.

Tentaculites gyracanthus subzone.-A wellmarked and persistent subzone carries Tentaculites gyracanthus, though in some of the sections where Tentaculites occurs at numerous horizons this subzone can be identified only by the characteristic association with Schuchertella prolifica.

Upper Leperditia subzone.-At Lewistown and Selinsgrove Junction Leperditia occurs at the very summit of the Keyser. This subzone may also be represented by the Leperditia at the top of the Mapleton section, though this is doubtful.

\section{COEYMANS LIMESTONE MEMBER.}

The Coeymans member is variable in its lithology. In the west it is locally arenaceous at the base and consists of coarse crinoidal limestone in the upper part. Farther east this sandy character extends through the whole of the member and becomes so pronounced at Grovania that the Coeymans is a sandstone. Usually chert is present.
The thickness of the Coeymans in the sections studied varies from 3 to 10 feet, though it is possible that the minimum thickness should be increased by including some of the overlying limestone.

The fauna is diagnostic, containing the characteristic species Gypidula coeymanensis, together with Atrypa reticularis, Camarotoechia sp., Dalmanella perelegans, Leptaena rhomboidalis, Lingula sp., Meristella sp., Photidops ovata, Rhipidomella oblata?, Schuchertella woolworthana, Stropheodonta arata, Strophonella Zeavenworthana, Spirifer cyclopterus, Uncinulus sp., Dalmanites sp., and Phacops logani.

The Coeymans-Keyser boundary is everywhere strikingly clean cut. The uppermost beds of the Keyser are platy, banded impure limestones. The base of the Coeymans is coarse, commonly arenaceous limestone or sandstone. The faunal change is likewise sharp.

\section{NEW SCOTLAND LIMESTONE MEMBER.}

The New Scotland member usually has a thin bed of limestone at its base, above which lie shales, interbedded in many places with impure limestone and with white chert.

In the vicinity of Dalmatia the basal limestone is very thin or lacking. It was likewise not observed in Perry County. At Tyrone it is 12 feet thick; at Lewiștown, 6 feet; at Selinsgrove Junction, 12 feet; at Grovania it seems to be about 13 feet thick and contains much shale. The limestone is arenaceous at Selinsgrove Junction, but in most other places it is simply a coarse-grained bluish-gray fossiliferous rock.

The fauna of the limestone contains the characteristic form Spirifer macropleurus and Atrypa reticularis?, Anoplotheca concava, Camarotoechia sp., Chonostrophia helderbergiae, Dalmanella perelegans, Eatonia medialis, Meristella sp., Orbiculoidea sp., Rhipidomella oblata, Schuchertella woolworthana, Stropheodonta planulata?, Stropheodonta becki?, Strophonella punctulifera, Spirifer cyclopterus, Spirifer perlamellosus, Uncinulus nucleolatus, Dalmanites pleuroptyx, Dalmanites micrurus, and Phacops logani.

The shale is ashy gray, fissile or splintery, and fine grained and contains more or less impure limestone in thin layers. It weathers yellow and is not usually very fossiliferous. The only measurement of the thickness, made 
at Selinsgrove Junction, gives a total of 44 feet. Tonoloway resembles the Bossardville limeSome uncertainty as to the position of the upper stone of New Jersey, but the lack of paleonboundary renders the accuracy of this figure only approximate.

The shale is relatively barren of fossils at most places, but at Dalmatia the following species were observed: Anoplotheca concava, Chonetes cf. C.hemisphericus, Dalmanella perelegans, Meristella sp., Pholidops ovata, Stropheodonta becki, Strophonella punctulifera, Spirifer cyclopterus, Spirifer perlamellosus, and Phacops logani?. At the Emerick \& Lebo quarry, 4 miles northeast of Dalmatia, Spirifer macropleurus was found in the shale.

The New Scotland-Coeymans boundary is not well defined lithologically. The division has been made arbitrarily between the highest beds with Gypidula coeymanensis and the lowest with Spirifer macropleurus.

\section{BECRAFT LIMESTONE MEMBER.}

No lithologic or faunal evidence of the presence of the Becraft member of the Helderberg was obtained at any locality studied.

\section{CORRELATION OF TONOLOWAY LIMESTONE.}

The Tonoloway limestone of central Pennsylvania includes the beds at Grovania, Selinsgrove Junction, and Dalmatia, referred by I. C. White to the Bossardville limestone. It includes also the beds at Clark's Mill, referred by Claypole to the Lewistown limestone, the term being used by him in a restricted sense. At the other localities treated in this paper it forms a part of "Formation No. VI," or the Lewistown limestone, these terms having been used so loosely as to prevent an exact statement of equivalency.

The Tonoloway in Pennsylvania agrees in all its lithologic details with the formation of the same name in Maryland. Both are mainly platy, laminated limestones. Both have, locally, heavy beds at the top.

As shown on page 188, the small fauna identified from Pennsylvania is duplicated in Maryland. Considering, then, the stratigraphic position, lithologic similarity, and faunal likeness, the identity of the Maryland and Pennsylvania Tonoloway seems assured.

The relations with the formations toward the east and north are more difficult to decipher. Lithologically and stratigraphically the tologic evidence from the Bossardville renders correlation with it uncertain. Camarotoechia? lamellata and Camarotoechia litchfieldensis occur in the Decker limestone of New Jersey and in the Cobleskill and Rondout of eastern New York. The former species occurs in the Cobleskill and Rondout and Ectomaria minuta in the Manlius of central New York. Inasmuch as these three forms occur also in the Keyser, it seems inadvisable to say more at present than that the Tonoloway is equivalent to some part of the late Silurian of the standard New York section.

\section{CORRELATION OF HELDERBERG LIMESTONE.}

KEYSER LIMESTONE MEMBER.

CORRELATION WITH BEDS IN MARYLAND.

The Keyser member of the Helderberg in Pennsylvania duplicates in a striking way the lithologic succession in Maryland. The lower beds in both are nodular and the upper relatively shaly. Banded, laminated impure limestones of varying thickness occur at the top of both. Both have Stromatopora reefs, and both have locally, as at Lewistown and Mapleton, a heavy crinoidal bed near the base.

The faunal likeness of the Pennsylvania sections (except those at Tyrone and Grovania) to sections in Maryland is as striking as the similarity in lithology. The same species occur with much the same stratigraphic ranges in both States. The same two major faunal zones are recognized in both, and these are divided into subzones which correspond in a remarkable fashion in the two areas. (See figs. 29 , p. 190 , and 30 , p. 194 .)

The following table affords a comparison:

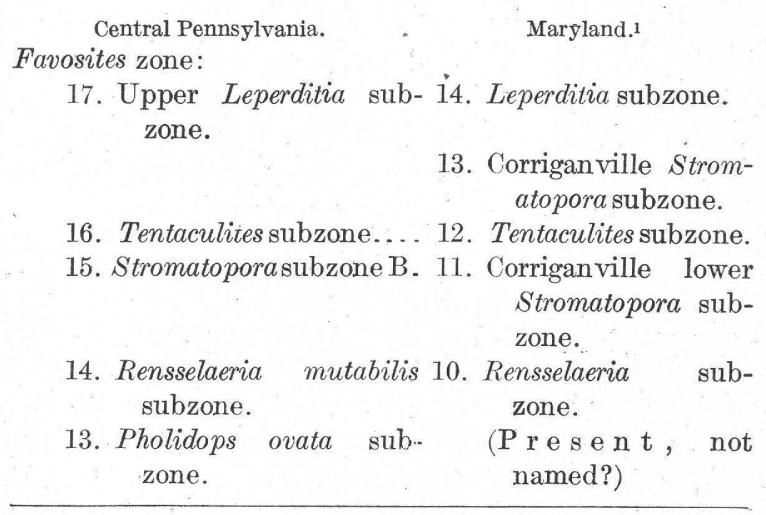

${ }^{1}$ Swartz, C. K., Maryland Geol. Survey, Lower Devonian, p. 99, 1913. 
Central PennsyIvania.

Favosites zone-Continued.

12. Lower Leperditia subzone.

11. Coral subzone B

10. Spirifer vanuxemi prognosticus subzone.

Chonetes zone:

9. Calymene camerata subzone.

8. Bryozoan subzone......

7. Gypidula subzone.
At Market Street Bridge, Cumberland, Md., there is an abundance of Camarotoechia lamellata near the base of the Keyser, which probably represents subzone 1 of central Pennsylvania. The occurrence of Dalmanella clarki at Cash Valley, about $3 \frac{1}{2}$ miles southwest of Cumberland, Md., harmonizes very well with subzone 6 of Pennsylvania. Spirifer vanuxemi var. prognosticus occurs at Millers Spring, near Ridgely, Md., at about the horizon of subzone

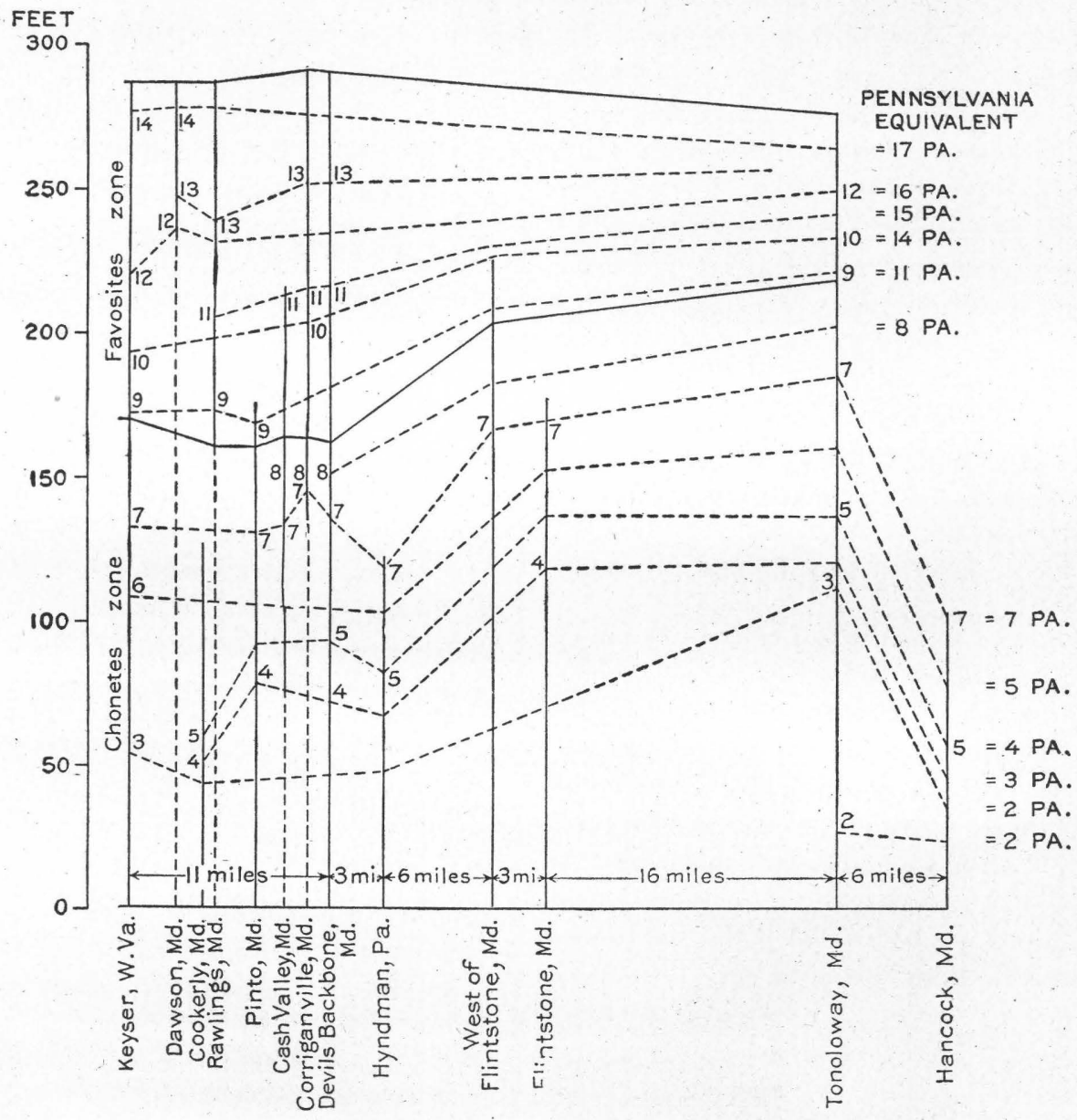

FIGURE 30.-Diagram showing relations of the zones and subzones of the Keyser limestone member of the Helderberg limestone in Maryland.

6. Dalmanella clarki sub- (P r e s e n t, not zone.

5. Spirifer modestus sub- 6. Cystid-Spirifer subzone. zone.

4. Stromatopora subzoneA. 5. Rawlings Stromatopora reef.

3. Coral subzone A

4. Cladopora rectilineata subzone.

2. Rhynchospira subzone... 2,3. Rhynchospira sub-

1. Camarotoechia? lamel- (Present, not lata subzone. named?)
10 of Pennsylvania. Leperditia gigantea occurs at Devils Backbone, near Cumberland, Md., above the "Corriganville lower Stromatopora reef" and may represent subzone 12 of Pennsylvania. The Pholidops ovata subzone and Calymene camerata subzone probably have parallel occurrences in Maryland. In short, the subzones of the more central sections in Pennsylvania are practically duplicated in Maryland. 
The sections at Tyrone and Grovania, however, offer some difficulty. In both the fauna of the Chonetes jerseyensis zone is well developed, though some of the subzones that are well marked in the other sections are not discernible in these two. The Favosites zone is characterized by the great abundance of corals and stromatoporoids. On the other hand, the remaining members of the upper fauna are conspicuously absent at Tyrone and almost lacking at Grovania. There are no sections in the Maryland area which present these peculiarities nor that of the small thickness shown in these two Pennsylvania sections. Possibly the facies exposed at Tyrone and Grovania is buried beneath the later rocks of .western Maryland, for the sections of the westernmost Maryland exposures most closely resemble those at Mapleton, Lewistown, and Selinsgrove. The chief difference lies in the lesser thickness in Pennsylvania.

These facts lead to the conclusion that the Keyser member of the Helderberg in Maryland and the Keyser member in central Pennsylvania are essentially identical.

\section{CORRELATION WITH BEDS IN NEW JERSEY.}

Weller ${ }^{1}$ divided the Lower Devonian and late Silurian limestones of New Jersey as follows:

$$
\begin{gathered}
\text { Helderberg: } \\
\text { Becraft. } \\
\text { New Scotland. } \\
\text { Coeymans. } \\
\text { Silurian: } \\
\text { Manlius. } \\
\text { Rondout. } \\
\text { Decker Ferry. } \\
\text { Bossardville. }
\end{gathered}
$$

The probable equivalence of the Bossardville and the Tonoloway has been mentioned (p. 193).

The Decker (or "Decker Ferry" limestone) was divided by Weller ${ }^{2}$ into the Chonetes jerseyensis zone, the Ptilodictya frondosa zone, and the Rhynchonella lamellata zone. The Chonetes jerseyensis zone contains a fauna which has many forms common in the lower zone of the Pennsylvania Keyser. The Ptilodictya frondosa zone, which is very thin in New Jersey, has not been recognized in Pennsylvania. The Rhynchonella lemellata zone of

1 Weller, Stuart, Paleontology of New Jersey, vol. 3, p. 9, 1903.

2 Idem, p. 67.
Weller contains many corals, including Cladopora rectilineata and Halysites catenulatus. The coral subzone A seems to correspond best with this zone, though it might possibly be equivalent to the coral subzone $B$.

The fauna of the Chonetes jerseyensis zone of Pennsylvania as a whole shows a marked relation to that of the Decker limestone of New Jersey. Of 41 species identified in the Chonetes jerseyensis zone of Pennsylvania 18, or 44 per cent, occur in the Decker and include its most diagnostic forms. It is probable that further study of the corals, pelecypods, ostracodes, and Bryozoa will show that the percentage of species common to the two units is still greater.

A very marked difference between the Decker limestone and the Chonetes jerseyensis zone of the Keyser limestone is the notable percentage of Devonian (typical Coeymans, New Scotland, and Becraft) forms in the Keyser. Three such species are present in New Jersey, but in Pennsylvania there are nine. In Maryland there are still more.

The lithology of the Decker is also like that of the Chonetes jerseyensis zone. The lithologic, faunal, and stratigraphic similarity therefore shows that the two units are essentially the same. If the coral subzone $\mathrm{B}$ is the equivalent of the coralline zone of the Decker, the upper beds of the Decker are younger than the upper beds of the Chonetes jerseyensis zone of the Keyser. The faunal succession given on page 194 makes it very likely that the coral reef of the Keyser of Maryland is equivalent to the coral subzone B. As the coral reef of the Keyser contains a number of species which are limited to the Favosites zone, the coral subzone B is probably not the equivalent of the coralline zone of the Decker. If, as seems more probable, then, the coral subzone $A$ is the equivalent of the coralline zone of the Decker, the upper beds of the Chonetes jerseyensis zone are younger than the upper beds of the Decker.

The Rondout of New Jersey has no welldefined equivalent in Pennsylvania. The presence of Leperditia in the Favosites zone suggests similarity of conditions, but there is no real evidence of equivalency.

The Manlius of New Jersey is characterized by the presence of Stromatopora-bearing beds and an abundance of Spirifer vanuxemi, Stropheodonta varistriata, and Leperditia alta. Tentaculites gyracanthus occurs but is rare. The 
Favosites zone of the Keyser of Pennsylvania contains stromatoporoids at three localities. Tentaculites gyracanthus occurs abundantly in it at four localities, rarely at Mapleton, and not at all at Grovania and Tyrone. Spirifer vanuxemi is represented by the variety prognosticus, a very abundant form in the Favosites zone of most of the sections, except again Tyrone and Grovania. This variety occurs also in the lower zone of Pennsylvania, but nowhere abundantly. Stropheodonta varistriata has not been observed in the central Pennsylvania sections, nor was it recognized farther south in Maryland. Leperditias related to if not identical with the New Jersey species are likewise known in the Favosites zone of Pennsylvania.

The most marked difference between the fauna of the New Jersey Manlius and that of the Favosites zone of Pennsylvania is the presence in the latter of five Devonian (Coeymans, New Scotland, and Becraft) species, in comparison with the single form of Devonian affinity in the New Jersey beds. A still larger number occur at the equivalent horizons in Maryland.

It is shown on page 199 that the Coeymans of central Pennsylvania is the same as the Coeymans in New Jersey and New York. The equivalency of the basal beds of the Keyser and the Decker having been established, it follows that the Keyser is included between the same limits as the Decker, Rondout, and Manlius of New Jersey. Considering this fact and the faunal and lithologic evidence, the equivalency of the formations appears to be as follows:

$$
\begin{aligned}
\text { Coeymans } & =\text { Coeymans. } \\
\text { Keyser } & =\left\{\begin{array}{l}
\text { Manlius. } \\
\text { Rondout. } \\
\text { Decker. }
\end{array}\right. \\
\text { Tonoloway } & =\text { Bossardville. }
\end{aligned}
$$

Possibly the top of the Keyser is somewhat younger than the top of the Manlius of New Jersey. It has been shown already that there is probably an unconformity between the Keyser and the Coeymans. Horizons present in Pennsylvania may be missing in New Jersey.

CORRELATION WITH BEDS IN NEW YORK.

\section{FORMATIONS EAST OF THE HELDERBERG MOUNTAINS.}

The formations in New York east of the Helderberg Mountains are continuous with those of New Jersey, the chief change being the development of cement beds and the consequent differentiation of new formations. Clarke and Hartnagel ${ }^{1}$ recognize the following succession in eastern New York:

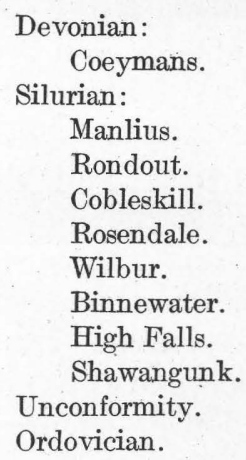

The Coeymans, Manlius, and Rondout are identical with the corresponding formations in New Jersey. There is a difference of opinion as to the equivalency of the Decker. Weller ${ }^{2}$ correlated it with the Cobleskill. Hartnagel, ${ }^{3}$ however, proposed to restrict the term to the Chonetes jerseyensis and Ptilodictya zones of Weller, and considered them equivalent to the Wilbur and Rosendale. Hartnagel divided Weller's Rhynchonella lamellata zone into two parts, considering only the upper to be of Cobleskill age. If Hartnagel is correct the Keyser is equivalent to the Wilbur-Manlius interval of eastern New York.

\section{FORMATIONS WEST OF THE HELDERBERG MOUNTAINS.}

Hartnagel and other authors consider the Cobleskill, Rondout, and Manlius of central New York equivalent to the formations of the same names in the eastern part of the State. If this is true the Keyser is equivalent to formations which have been accepted as Silurian. The Tonoloway horizons would then be considered as entirely lacking in central New York. Ulrich ${ }^{4}$ proposes a view quite different from this generally accepted one-namely, that the Cobleskill-Rondout-Manlius interval of eastern New York is not the same as that of central New York, but that the latter is for the most part older. Ulrich believes that the Manlius

\footnotetext{
1 Hartnagel, C. A., Classification of the geologic formations of the State of New York: New York State Mus. Handbook 19, Table 2, 1912.

2 Weller, Stuart, Paleontology of New Jersey, vol. 3, pp. 74-75, 1903.

${ }^{3}$ Hartnagel, C. A., Notes on the Siluric or Ontaric section of eastern New York: New York State Mus. Fifty-seventh Ann. Rept., vol. 1, pt. 1, p. 348,1905

4 U. S. Geol. Survey Geol. Atlas, Pawpaw-Hancock folio (No. 179), 1912; Maryland Geol. Survey, Lower Devonian, pp. 115-117, 1913.
} 
of the central area contains four divisions, which may be named and correlated as follows:

Manlius of different authors (central area):

Upper beds = Manlius of eastern New York.

Cement beds $\quad=$ Rondout of eastern New York (typical).

Fossiliferous beds =Cobleskill of eastern New York (typical). Same as Decker.

Typical Manlius of central New York.

Rondout of central New =Tonoloway of Pennsylvania York.

Cobleskill of central New

York. and Maryland.

In other words, the typical Manlius of Ulrich, the Rondout, and the Cobleskill of the central area are, in Ulrich's opinion, the equivalent of the Tonoloway of the south and are Silurian, while most of the Manlius of different authors of the central area is equivalent to the typical Cobleskill (same as the Decker, in Ulrich's opinion), the typical Rondout, and the socalled Manlius of eastern New York and is Devonian. There is much to substantiate this view in the relations of the Tonoloway fauna as shown in Pennsylvania and as more fully represented in Maryland. The close relationship of the central New York Cobleskill and the Decker is explained by Ulrich as a recurrence of the fauna of the former in the latter formation. However, the presence of diagnostic Decker forms in the "fossiliferous beds" of the central New York Manlius has not been demonstrated, and Ulrich's solution of the problem can not be finally accepted until this evidence is brought forward, though it does offer a very logical way out of the difficulty.

COEYMANS, NEW SCOTLAND, AND BECRAFT ELEMENTS IN THE KEYSER FAUNA.

The Pennsylvania Keyser as a whole contains 13 species (28 per cent of the species that occur elsewhere) which are found in the Coeymans, New Scotland, and Becraft of New York. Eleven of these (30 per cent of the species of the Chonetes jerseyensis fauna that occur elsewhere) are found in the Chonetes jerseyensis zone, and six (38 per cent of the species of the Favosites fauna that occur elsewhere) are found in the Favosites helderbergiae var. praecedens zone. If only the number of forms common to the Keyser and the New York and New Jersey Helderberg formations is used as a basis, the percentages of Devonian forms rise to 43 per cent for the whole Keyser, 34 per cent for the $103969^{\circ}-17-3$
Chonetes jerseyensis zone, and 45 per cent for the Favosites zone.

In the Maryland Keyser there are 31 species (or 43 per cent of the forms that occur elsewhere) which also occur in the Coeymans, New Scotland, and Becraft of New York. Of these, 19 species (30 per cent of the Chonetes jerseyensis fauna) occur in the Chonetes jerseyensis zone and 12 species ( 60 per cent of the forms that occur elsewhere) in the Favosites zone.

In the Decker of New Jersey the Devonian (Coeymans, New Scotland, and Becraft) element is very small. Only two such species are cited, ${ }^{1}$ with one that is related to a Devonian form-Photidops ovata, Rhynchospira formosa, Stenoschisma deckerensis. The New Jersey Rondout, judged by the published lists, has no Devonian elements, and the Manlius has a single form with Devonian affinities-Stropheodonta varistriata.

There seems to be thus a progressive decrease northward in the Devonian aspect of the Keyser and its equivalents. Possibly the Devonian fauna invaded the Maryland area first, attained a lesser development in Pennsylvania, and did not reach New Jersey and New York in large numbers until Coeymans time.

The species of the Chonetes zone that occur in the Coeymans, New Scotland, and Becraft of New York or have very close relatives there are Photidops ovata, Orthostrophia strophomenoides, Strophonella leavenworthana var., Stenoschisma formosa, Rhynchospira globosa var., Rhynchospira formosa, Nucleospira ventricosa, Nucleospira elegans, and Proetus protuberans. The species in the Favosites zone are Orbiculoidea discus, Pholidops ovata, Uncinutus nucleolatus, Rensselaeria mutabilis, $\mathrm{Nu}$ cleospira elegans, and Favosites helderbergiae var. praecedens.

\section{ANALYSIS OF THE FAUNA.}

The following table summarizes the relations of the species of the Keyser member in. Pennsylvania to those of other horizons and other areas. The figures given here are based on the table of distribution on pages 200-203. The occurrences cited for Maryland, New Jersey, and New York are taken from publications of the Maryland Geological Survey, New Jersey Geological Survey, and New York State Museum.

1 Weller, Stuart, Paleontology of New Jersey, vol. 3, p. 74, 1903. 


\begin{tabular}{|c|c|c|c|c|c|c|c|c|}
\hline & \multicolumn{2}{|c|}{$\begin{array}{l}\text { Keyser } \\
\text { member. }\end{array}$} & \multicolumn{2}{|c|}{$\begin{array}{l}\text { Chonetes } \\
\text { zone. }\end{array}$} & \multicolumn{2}{|c|}{$\begin{array}{l}\text { Favosites } \\
\text { zone. }\end{array}$} & \multicolumn{2}{|c|}{$\begin{array}{l}\text { Transition } \\
\text { zone. }\end{array}$} \\
\hline & $\begin{array}{l}\text { Num- } \\
\text { ber. }\end{array}$ & $\begin{array}{l}\text { Per } \\
\text { cent. }\end{array}$ & $\begin{array}{l}\text { Num- } \\
\text { ber. }\end{array}$ & $\begin{array}{c}\text { Per } \\
\text { cent. }\end{array}$ & $\begin{array}{l}\text { Num- } \\
\text { ber. }\end{array}$ & $\begin{array}{l}\text { Per } \\
\text { cent. }\end{array}$ & $\begin{array}{l}\text { Num- } \\
\text { ber. }\end{array}$ & $\begin{array}{l}\text { Per } \\
\text { cent. }\end{array}$ \\
\hline \multirow[t]{2}{*}{ 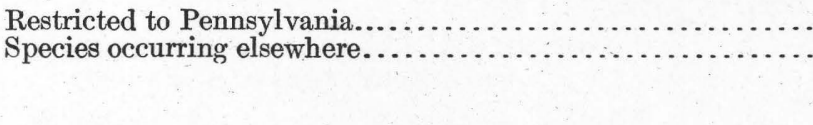 } & $\begin{array}{r}6 \\
49\end{array}$ & $\begin{array}{l}11 \\
89\end{array}$ & $\begin{array}{r}4 \\
41\end{array}$ & $\begin{array}{r}9 \\
91\end{array}$ & $\begin{array}{r}2 \\
16\end{array}$ & $\begin{array}{l}11 \\
89\end{array}$ & $\begin{array}{r}0 \\
12\end{array}$ & $\begin{array}{r}0 \\
100\end{array}$ \\
\hline & 54 & 100 & 45 & 100 & 18 & 100 & 12 & 100 \\
\hline \multirow{5}{*}{ 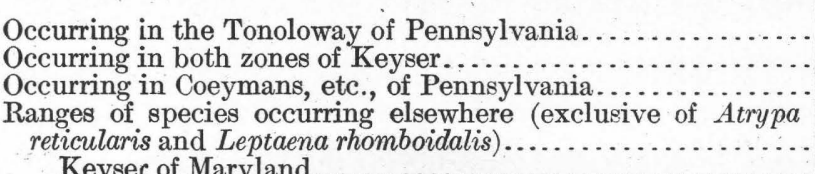 } & 4 & 8 & 4 & 9 & 0 & 0 & & \\
\hline & 8 & 15 & 8 & 18 & 8 & 44 & & \\
\hline & 2 & 4 & 2 & 4 & 0 & 0 & & \\
\hline & 47 & & 39 & & 16 & & & \\
\hline & 38 & 81 & गy & & 10 & & & \\
\hline 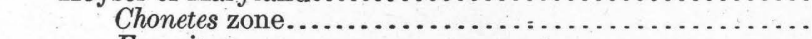 & 32 & 68 & 31 & 80 & 6 & 38 & & \\
\hline Favosites zone.................... & 11 & 23 & 4 & 10 & 11 & 75 & & \\
\hline Decker of New Jersey............. & 16 & 34 & 16 & 41 & 5 & 31 & & \\
\hline Rondout of New Jersey.............. & 0 & 0 & 0 & 0 & 0 & 0 & & \\
\hline Manlius of New Jersey................................. & 3 & 6 & 3 & 8 & 1 & 6 & & \\
\hline Wilbur of eastern New York....... & 5 & 11 & 5 & 13 & 1 & 6 & & \\
\hline Cobleskill of eastern New York........ & 7 & 15 & 7 & 18 & 2 & 13 & & \\
\hline Rondout of eastern New York... & 4 & 9 & 4 & 10 & 0 & 0 & & \\
\hline Manlius of eastern New York... & 2 & 4 & 2 & 6 & 2 & 13 & & \\
\hline Cobleskill of central New York... & 5 & 11 & 5 & 13 & $\overline{1}$ & 6 & & \\
\hline Rondout of central New York...... & 3 & 6 & 3 & 8 & 1 & 6 & & \\
\hline Manlius of central New York............. & 4 & 9 & 4 & 10 & 1 & 6 & & \\
\hline Coeymans and New Scotland...... & 13 & 28 & 11 & 30 & 5 & 31 & & \\
\hline \multirow{2}{*}{\multicolumn{9}{|c|}{ 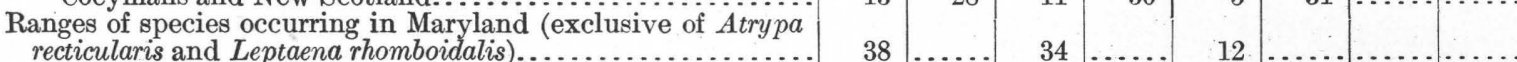 }} \\
\hline & 38 & & 34 & & 12. & & & \\
\hline Chonetes zone of the Keyser member .............. & 32 & 84 & 31 & 91 & 6 & 50 & & \\
\hline Favosites zone of Keyser member.... & 11 & 29 & 4 & 12 & 11 & 92 & & \\
\hline \multirow{2}{*}{\multicolumn{9}{|c|}{ Ranges of species occurring in New Jersey and New York...................... }} \\
\hline & 16 & $\ddot{53}$ & 16 & 57 & 5 & 45 & & \\
\hline Rondout of New Jersey & 0 & 0 & 0 & 0 & 0 & 0 & & \\
\hline Manlius of New Jersey..... & 3 & 10 & 3 & 11 & 1 & 9 & & \\
\hline Wilbur of eastern New York & 5 & 17 & 5 & 18 & 1 & 9 & & \\
\hline Cobleskill of eastern New York............. & 7 & 23 & 7 & 25 & 2 & 18 & & \\
\hline Rondout of eastern New York. & 4 & 13 & 4 & 14 & 0 & 0 & & \\
\hline Manlius of eastern New York & 2 & 7 & 2 & 7 & 2 & 18 & & \\
\hline Cobleskill of central New York............ & 5 & 17 & 5 & 18 & 1 & 9 & & \\
\hline Rondout of central New York ............... & 3 & 10 & 3 & 11 & 1 & 9 & & \\
\hline Manlius of central New York & 4. & 13 & 4 & 14 & 1 & 9 & & \\
\hline Wilbur to Manlius of eastern New York and New Jersey & 20 & 66 & 20 & 71 & 7 & 64 & & \\
\hline Cobleskill to Manlius of central New York.. & 9 & 30 & 9 & 32 & 3 & 27 & & \\
\hline Wilbur to Manlius of New York and New Jersey... & 21 & 70 & 20 & 71 & 9 & 82 & & \\
\hline Coeymans to Becraft of New York..................... & 13 & 43 & 10 & 34 & 5 & 45 & & \\
\hline
\end{tabular}

\section{AGE OF THE KEYSER LIMESTONE MEMBER.}

The Keyser limestone member, as shown above, lies between the Coeymans and beds of unquestioned Silurian age. It is furthermore clearly equivalent to the Keyser of Maryland; - which contains a large number of Coeymans, New Scotland, and Becraft forms, and to the Decker, Rondout, and Manlius of New Jersey and eastern New York; which contain very few Coeymans, New Scotland, and Becraft species. If the age of $\dot{a}$ formation is determined by the youngest element in the fauna, the Keyser is Devonian. If the percentage of an older fauna surviving is taken as the significant factor, the Keyser is likewise Devonian, for it has but few forms in common with the pre-Keyser beds. If, also, considering the small number of species common to the Keyser and the Cayuga group of central New York, Ulrich is correct in the view that these species in the Keyser are really a recurrence, and that the Cayuga of central New York is mainly older than the supposed equivalent in eastern New York, we have a rational explanation for the differences between the deposits of eastern and central New York commonly grouped as Cayuga and for the more definitely Silurian aspect of the Cayuga of the central area. However, the presence of characteristio Decker forms in the "fossiliferous zone" of the Manlius of centra] 
New York (see p. 197) has not yet been demonstrated, and a definite decision must await th further investigation. For the present, it seems to the writer that the weight of the evidence favors the reference of the Keyser to the Devonian.

No physical evidence of unconformity was observed at the base of the Keyser in any of the sections studied, but the sharp faunal change and the ordinarily sharp lithologic change at that horizon are very suggestive of a break in the succession and to that extent favor the argument for the Devonian age of the Keyser beds.

\section{COEYMANS LIMESTONE MEMBER.}

The Coeymans member of the Helderberg of central Pennsylvania is clearly to be correlated with the beds at the corresponding horizons in Maryland, in New Jersey, and in New York. There is a suggestion of an unconformable contact at the base of the member in Maryland, and still stronger evidence for it in Pennsylvania, New Jersey, and New York. The fauna is marked in all the areas by the presence of the guide fossil Gypidula coeymanensis.

Of the ten species identified from the Coeymans of Pennsylvania nine occur in the Coeymans of Maryland and eight in the Coeymans of New Jersey and New York.

\section{NEW SCOTLAND LIMESTONE MEMBER.}

The New Sootland member is closely related to the beds at the same horizon in Maryland and in New Jersey and New York. The presence of Spirifer macropleurus and other diagnostic forms makes the connection intimate. The species identified from the New Scotland of Pennsylvania number fifteen, of which thirteen (87 per cent) occur in the New Scotland of Maryland and fourteen (93 per cent) in the New Scotland of New Jersey and New York.

\section{DISTRIBUTION OF THE FAUNA.}

The following table gives a detailed statement of the occurrence of the fossils found in the Tonoloway and Helderberg limestones: 
$[\mathrm{R}$ indicates a related form.

\begin{tabular}{|c|c|c|c|c|c|c|c|c|c|c|c|c|c|c|c|c|c|c|c|c|c|c|c|c|c|c|}
\hline \multicolumn{6}{|c|}{ Pennsylvania. } & \multicolumn{5}{|c|}{ Maryland. } & \multicolumn{5}{|c|}{ New Jersey. } & \multicolumn{11}{|c|}{ New York. } \\
\hline \multirow[b]{3}{*}{ 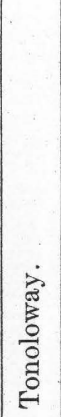 } & \multicolumn{5}{|c|}{ Helderberg. } & \multicolumn{5}{|c|}{ Helderberg. } & \multirow[b]{3}{*}{$\begin{array}{l}\text {. } \\
\text { cy } \\
0 \\
0 \\
0\end{array}$} & \multirow[b]{3}{*}{ 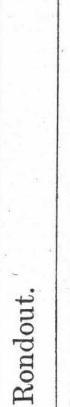 } & \multirow[b]{3}{*}{ 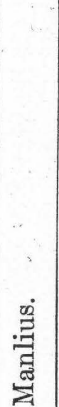 } & \multicolumn{2}{|c|}{$\begin{array}{c}\text { Helder- } \\
\text { berg. }\end{array}$} & \multicolumn{4}{|c|}{ Eastern. } & \multicolumn{3}{|c|}{ Central. } & \multicolumn{2}{|c|}{$\begin{array}{l}\text { Helder- } \\
\text { berg. }\end{array}$} & \multirow{3}{*}{ 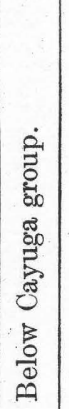 } & \\
\hline & \multicolumn{3}{|c|}{ Keyser. } & \multirow[b]{2}{*}{ 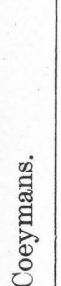 } & \multirow[b]{2}{*}{ 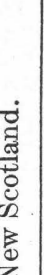 } & \multirow[b]{2}{*}{ 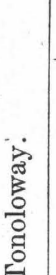 } & \multicolumn{2}{|c|}{ Keyser. } & \multirow[b]{2}{*}{ 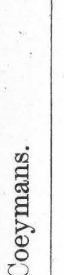 } & \multirow[b]{2}{*}{ 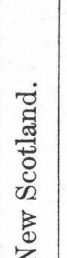 } & & & & \multirow[b]{2}{*}{ 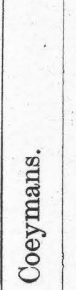 } & \multirow[b]{2}{*}{ 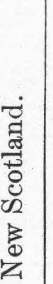 } & \multirow[b]{2}{*}{$\begin{array}{l}\dot{\Xi} \\
\hat{\Xi} \\
\vec{z}\end{array}$} & \multirow[b]{2}{*}{ 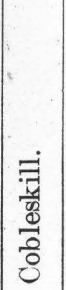 } & \multirow[b]{2}{*}{ 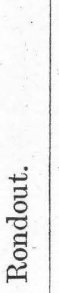 } & \multirow[b]{2}{*}{ 窵 } & \multirow[b]{2}{*}{$\begin{array}{l}\overline{7} \\
\frac{1}{9} \\
\frac{3}{0} \\
0 \\
0\end{array}$} & \multirow[b]{2}{*}{ 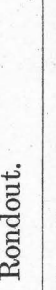 } & \multirow[b]{2}{*}{ 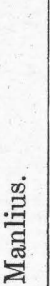 } & \multirow[b]{2}{*}{ 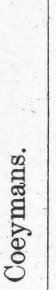 } & \multirow[b]{2}{*}{ 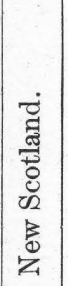 } & & \\
\hline & 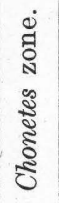 & 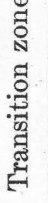 & 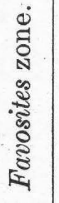 & & & & 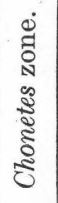 & 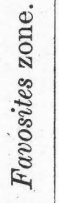 & & & & & & & & & & & & & & & & & & $\begin{array}{l}\frac{0}{0} \\
\frac{0}{0} \\
11 \\
0 \\
0\end{array}$ \\
\hline
\end{tabular}

Coelenterata

1. Favosites sp.

2. Cladopora rectilineata Simpson

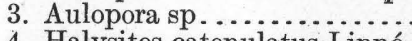

4. Halysites catenulatus Linné...

5. Stromatoporoidea, undetermined ....

\section{Echinodermata.}

6. Sphaerocystites multifasciata Hall.

7. Crinoidea, undetermined.............. $\times$

\section{Vermes.}

8. Spirorbis laxus Hall

9. Spirorbis sp

Molluscoidea.

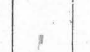

\section{.}
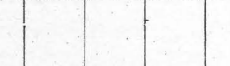

10. Bryozoa, undetermined

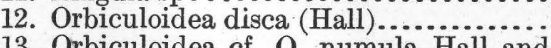

13. Orbiculoidea cf. O. numula Hall and Clarke...

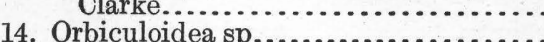

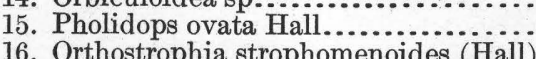

17. Dalmanella concinna (Hall)

18. Dalmanella clarki Maynard. 
19. Dalmanella cf. D. perelegans (Hall) $\ldots . . \ldots \times \mid \ldots$. 20. Dalmanella perelegans (Hall)

21. Dalmanella sp.

2. Rhipidomella emarginata (Hall)

23. Rhipidomella oblata (Hall

24. Leptaena rhomboidalis (Wilckens)

25. Stropheodonta arata (Hall)

26. Stropheodonta beckii (Hall).

28. Stropheodonta bipartita (Hall)

29. Stropheodonta sp.

30. Strophonella geniculata (Hail)

31. Strophonella leavenworthana (Hall)

32. Strophonella leavenworthana (Hall) var

33. Strophonella punctulifera (Conrad).

34. Schuchertella prolifica Schuchert.

35. Schuchertella woolworthana (Hall)

36. Schuchertella deckerensis (Weller)

38. Schuchertella swartzi Reeside.

38. Schuchertella swartzi Reeside.

40. Chonetes jerseyensis Weller.

41. Chonetes cf. C. hemisphericus Hall

42. Chonostrophia helderbergiae Hall and

43. Gypidula coeymanensis Schuchert.

44. Gypidula coeymanensis prognostica Maynard.

45. Stenoschisma formosa (Hall)

46. Stenoschisma deckerensis (Weller)

47. Camarotoechia lamellata Hall .

48. Camarotoechia litchfieldensis Schuchert

49. Camarotoechia sp.

50. Uncinulus nucleolatus (Hall).

51. Uncinulus keyserensis Schuchert

52. Uncinulus convexorus Maynard?

53. Uncinulus mutabilis Hall var.

54. Uncinulus gordoni Maynard?.........

Reeside.....

56. Uncinulus sp.

57. Wilsonia globosa Weller..

58. Eatonia medialis (Vanuxem)

59. Rensselaeria mutabilis (Hall).

61. Rensselaeria obtusa Reeside.

62. Rensselaeria (Beachia) proavita Schichert. .

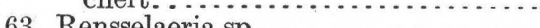

64. Atrypa reticularis (Linné)

65. Atrypa rugosa Hall.

66. Spirifer macropleurus (Conrad)

67. Spirifer perlamellosus H

69. Spirifer modestus plicatus Maynard

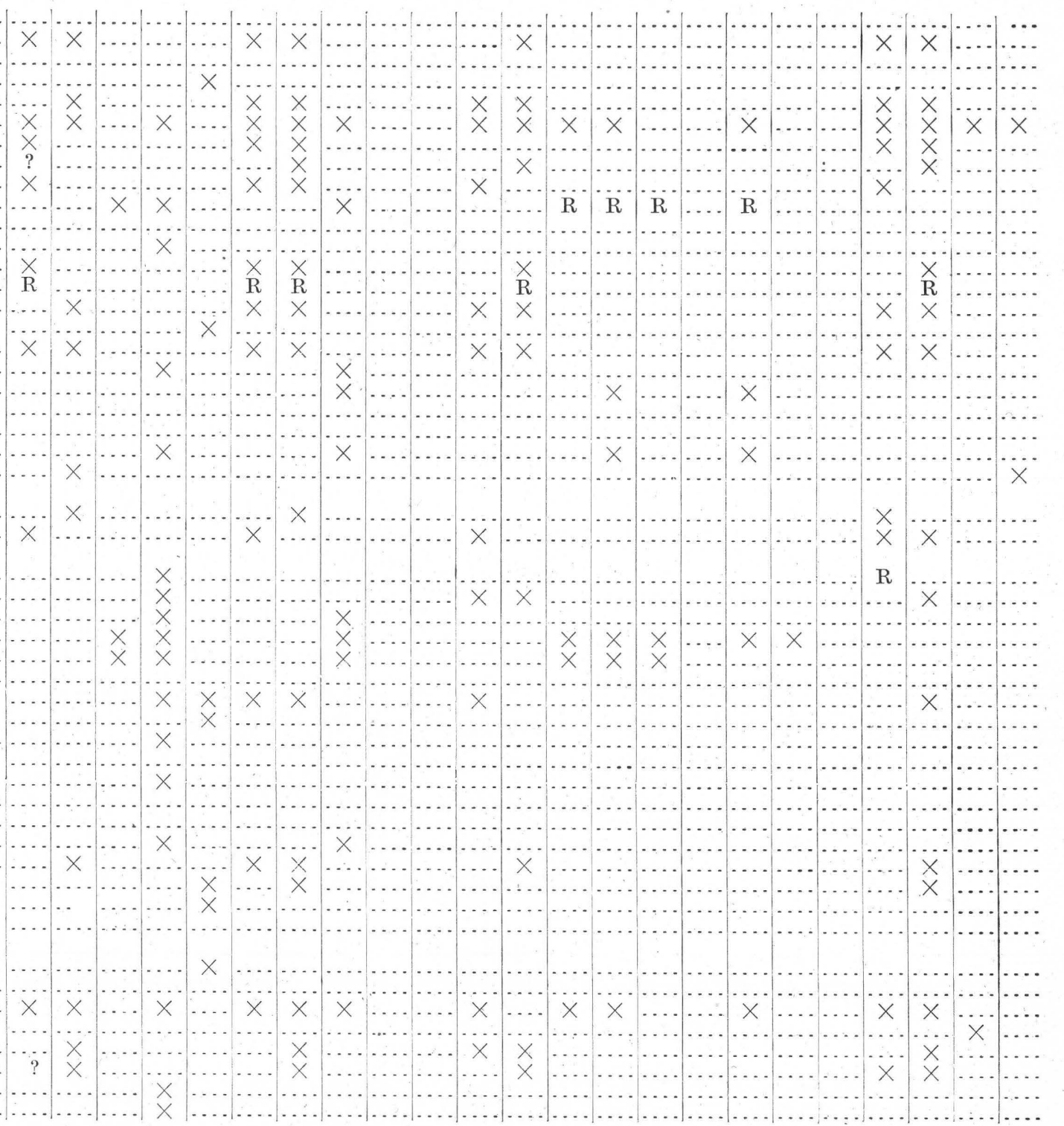


Distribution of Tonoloway and Helderberg fossils-Continued.

[ $R$ indicates a related form.]

\begin{tabular}{|c|c|c|c|c|c|c|c|c|c|c|c|c|c|c|c|c|c|c|c|c|c|c|c|c|c|c|}
\hline \multicolumn{6}{|c|}{ Pennsylvania. } & \multicolumn{5}{|c|}{ Maryland. } & \multicolumn{5}{|c|}{ New Jersey. } & \multicolumn{11}{|c|}{ New York. } \\
\hline & \multicolumn{5}{|c|}{ Helderberg. } & \multicolumn{5}{|c|}{ Helderberg. } & \multirow[b]{3}{*}{ 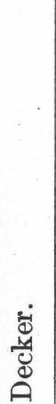 } & \multirow[b]{3}{*}{ 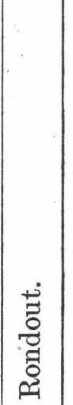 } & \multirow[b]{3}{*}{ 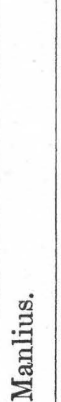 } & \multicolumn{2}{|c|}{$\begin{array}{c}\text { Helder- } \\
\text { berg. }\end{array}$} & \multicolumn{4}{|c|}{ Eastern. } & \multicolumn{3}{|c|}{ Central. } & \multicolumn{2}{|c|}{$\begin{array}{c}\text { Helder- } \\
\text { berg. }\end{array}$} & \multirow{3}{*}{ 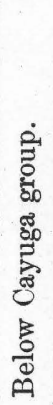 } & \multirow{3}{*}{ 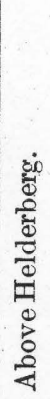 } \\
\hline & \multicolumn{3}{|c|}{ Keyser. } & \multirow[b]{2}{*}{ 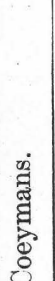 } & \multirow[b]{2}{*}{ 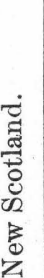 } & \multirow[b]{2}{*}{$\begin{array}{l}\text { के } \\
\text { है } \\
0 \\
0 \\
0 \\
0 \\
0\end{array}$} & \multicolumn{2}{|c|}{ Keyser. } & \multirow[b]{2}{*}{ 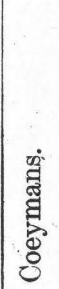 } & 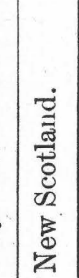 & & & & \multirow[b]{2}{*}{ 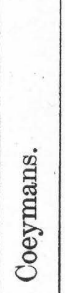 } & \multirow[b]{2}{*}{ 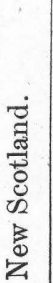 } & \multirow[b]{2}{*}{ 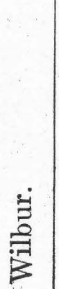 } & \multirow[b]{2}{*}{ 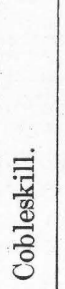 } & \multirow[b]{2}{*}{ 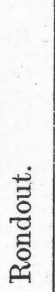 } & \multirow[b]{2}{*}{ 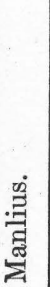 } & \multirow[b]{2}{*}{ 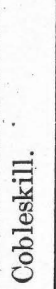 } & \multirow[b]{2}{*}{ 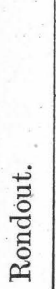 } & \multirow[b]{2}{*}{ 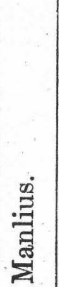 } & \multirow[b]{2}{*}{ 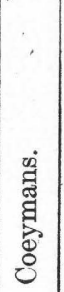 } & \multirow[b]{2}{*}{ 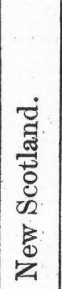 } & & \\
\hline 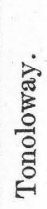 & 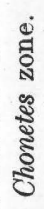 & 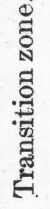 & 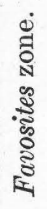 & & & & 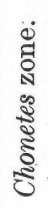 & 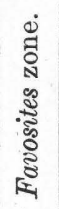 & & & & & & & & & & & & & & & & & & \\
\hline
\end{tabular}

Molluscoidea-Continued.

70. Spirifer octocostatus Hall

71. Spirifer vanuxemi Hall

72. Spirifer vanuxemi proonosticus Swartz.....

73. Spirifer keyserensis Swart

74. Spirifer eriensis Grabau

75. Spirifer cyclopterus Hall.

76. Spirifer sp.

77. Rhynchospira globosa (Hali) var.

8. Rhynchospira formosa Hall

79. Rhynchospira lata Reeside

81. Nucleospira ventricosa (Hail)

82. Nucleospira elegans Hall .

83. Nucleospira swartzi Maynard

84. Nucleospira sp...............

85. Anoplotheca concava (Hall) ....

86. Anoplotheca flabellites (Conrad)

87. Whitfieldella? prosseri Grabau.

88. Whitfieldella cf. W. nucleolata Hall

89. Meristella praenuntia Schuchert.

90. Meristella sp

\section{Mollusca.}

92. Pelecypoda, undetermined.

93. Tremanotus profundus Hall?

94. Bellerophon auriculatus? Hal 
95. Ectomaria sp.

96. Coelidium pennsylvanicum Reeside.

97. Coelidium dalmatiae Reeside.........

.

9. Hormotoma sp...

101. Holopea antiqua (Vanuxem)

102. Holopea sp

. Loxonema fitchi Hall?

106. Platystoma niagarensis Hali.

107. Tentaculites gyracanthus (Eaton)

107. Tentaculites gyracanthus (Eaton)

109. Orthoceras cf. O. pauciseptum Hall.

110. Orthoceras sp.

111. Phragmas s...

Arthropoda.

112. Goldius barrandi (Hall)

112. Goldius barrandi (Hall)...........

113. Proetus pachydermatus Barrett.........

114. Proetus protuberans Hall

116. Cyphaspis cf. C. minusculus (Hail)

117. Calymene camerata Conrad

118. Phacops logani Hall .

119. Dalmanites micrurus (Green)

120. Dalmanites pleuroptyx (Green). .

121. Dalmanites sp.

123. Ostracoda, undetermined

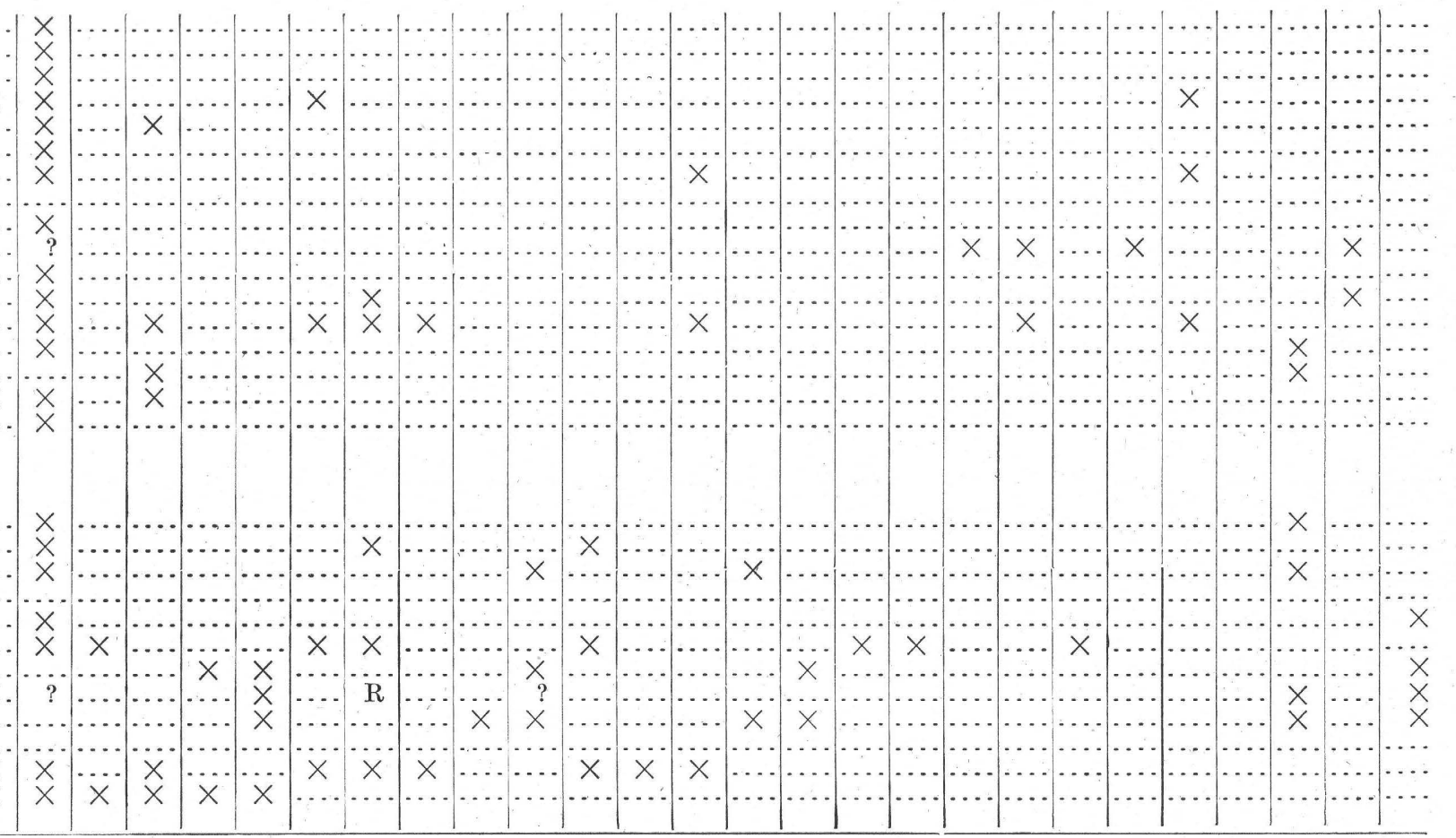




\section{SUMMARY.}

The facts presented in the foregoing pages lead to the following conclusions:

1. The Tonoloway limestone and the Keyser, Coeymans, and New Scotland members of the Helderberg limestone may be traced from Maryland through central Pennsylvania with their respective characteristic lithology and faunas, and the essential equivalents of all are to be found in New Jersey and eastern New York.

2. The equivalents of the Tonoloway and Keyser in central New York are in doubt, though Ulrich's view (p. 197) is very suggestive and may prove to be correct.

3. The beds referred to the Tonoloway at Tyrone, Pa., differ from those found in that formation elsewhere, and the sharpness of the supposed Keyser-Tonoloway contact suggests an unconformity. Further work may show that the beds immediately in contact with the Keyser at this point are of Wills Creek age.

4. The Keyser member decreases in thickness northward from Maryland.

5. The Devonian elements in the fauna apparently decrease from Maryland to New Jersey and New York.

6. The Tyrone and Grovania sections of the Keyser limestone resemble each other and differ very materially from the remaining sections in Pennsylvania and from the Maryland sections.

7. The Tonoloway limestone and the Keyser member of the Helderberg limestone in Maryland and Pennsylvania and their probable equivalents in New Jersey were possibly laid down in a basin which was connected with the open sea in the Maryland region and was progressively restricted northward and eastward to New Jersey. There may have been also a second basin which included the Tyrone and Grovania regions. Conditions in this second basin were different and favored the growth of corals and stromatoporoids, owing to a greater distance from the source of sediments or to the presence of some sort of barrier on the east.

8. The suggestion of an unconformity at the top of the Keyser in Maryland is borne out in Pennsylvania by the variations in thickness of the member and the presence of arenaceous material at the base of the Coeymans.
LOCAL SECTIONS OF THE TONOLOWAY AND HELDERBERG LIMESTONES.

In the following discussion the figures following the name of a fossil indicate the stratigraphic distance in feet at which the form occurs above the base of the member containing it. The distances in the Tonoloway formation are given by negative figures which indicate the stratigraphic distance in feet below the base of the Keyser at which the form occurs. The letters a and c mean abundant and common, respectively.

\section{LINCOLN AND FIFTEENTH STREETS, TYRONE.}

The exposure represented by the subjoined section begins just behind the house on the southwest corner of Lincoln and Fifteenth streets, Tyrone. It extends along a small creek known locally as Sink Creek and, as the dip is high, comprises within a short horizontal distance an excellent section of part of the Tonoloway formation and the Keyser, Coeymans, and New Scotland limestones.

The Tonoloway-Keyser contact is marked by the abrupt appearance of the Chonetes jerseyensis fauna and by the change in lithology from the light-colored limestones of the Tonoloway formation to the darker beds of the Keyser, though parts. of the Keyser are unusually light colored and resemble the Tonoloway. The Keyser-Coeymans contact is shown by the abrupt change from the impure platy finegrained limestone of the uppermost Keyser to the coarsely crystalline limestone of the Coeymans and by the presence of the characteristic Coeymans fauna. The Coeymans-New Scotland contact is not very sharply defined lithologically. In the section it is placed arbitrarily beneath the lowest beds containing Spirifer macropleurus. It is probable that at least part of the concealed unit at the top of the section is of New Scotland age.

Schuchert, ${ }^{1}$ in discussing the Lower Devonian of this locality, refers $\mathbf{1 1 5}$ feet of the section to the Keyser limestone, stating that the "cystid member" is present at the base and several Stromatopora-bearing beds toward the top. The beds beneath the Keyser he referred to the Cayuga; the beds overlying the Keyser he con-

1 Schuchert, Charles, Silurian formations in southeastern New York, New Jersey, and Pennsylvania: Geol. Soc. America Bull., vol. 27, p. 552, New 1916. 
siders Oriskany and believes therefore that the Coeymans, New Scotland, and Becraft are absent. However, as the following description shows, both the Coeymans and New Scotland are represented.

Section at Lincoln and Fifteenth streets, Tyrone.

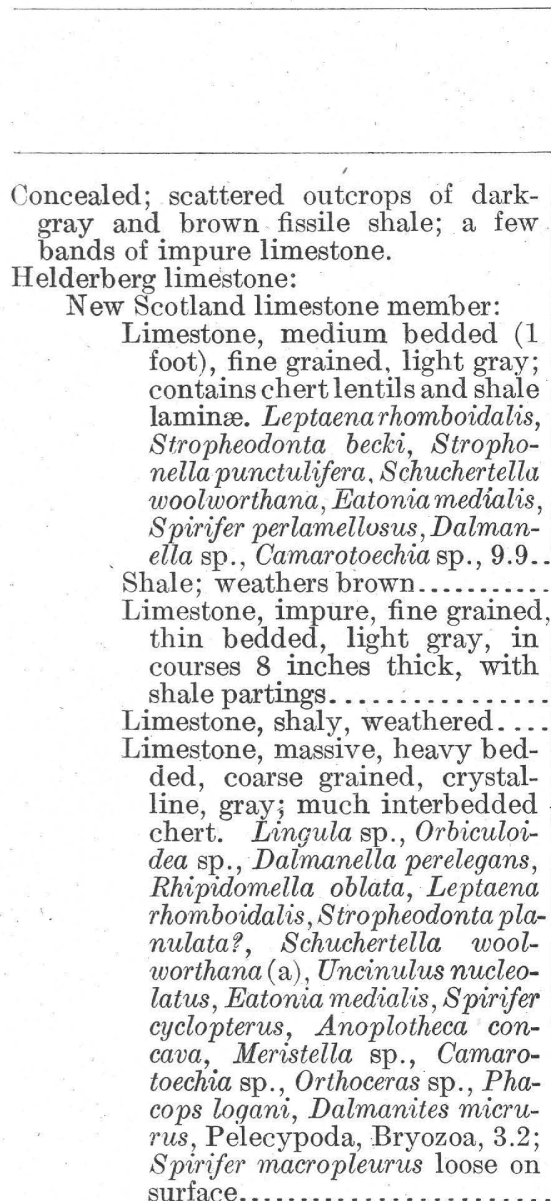

Coeymans limestone member:

Limestone, very impure, shaly, yellowish. Atrypa reticularis, Spirifer sp., Dalmanites sp., Bryozoa, 5.5.................

Limestone, somewhat weathered, light gray, coarsely crystalline; line of chert nodules $(2$ by 10 inches) near the top. Dalmanella perelegans, Stropheodonta arata, Gypidula coeymanensis, Atrypa reticularis, Spirifer cf. $S$. perlamellosus, Dalmanites

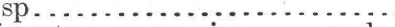

Limestone, massive, coarsely crystalline, dark.
Section at Lincoln and Fifteenth streets, Tyrone-Contd.

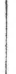

Helderberg limestone-Continued.

Keyser limestone member:

Limestone, single bed, light gray, fine grained, impure...........

Limestone, very shaly, light gray ............................

Limestone, light gray, fine
grained, platy...............

Shale, brown, weathered........

Limestone, light gray, fine grained, platy...............

Shale, brown, weathered.......

Limestone, impure, brownish gray, very platy; breaks into sheets half an inch thick. Pelecypoda...................

Limestone, pure, fine grained, brownish gray; in two beds separated by brown shale; has conchoidal fracture............

Limestone, shaly, banded, dark gray; contains carbonaceous

films. Leperditia sp., 69.8 .....
Limestone, composed entirely of stromatoporoids; Leperditia

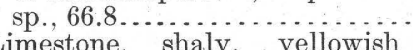
Limestone, shaly, yellowish
gray. Scattered heads of gray. Scattered heads of stromatoporoids at $67.0 \ldots \ldots . .$.
Limestone, composed entirely of stromatoporoids; under surface very irregular..... . . . . . .

Shale, brown, weathered.

Limestone, composed entirely of stromatoporoids and corals; under surface irregular........

Limestone, buff, fine grained, shaly ...............................
imestone, extremely massive,

Limestone, extremely massive, Bryozoa, and stromatoporoids .....................

Limestone, with profusion of corals and stromatoporoids......

Limestone, coarsely crystalline,

gray..............................

gray. Scattered stromatoporoids, Favosites sp., Aulopora sp., Calymene camerata,

36.8 . . . . . . . . . . . . . . . .
Limestone, coarsely crystalline, gray. Dalmanella concinna, Calymene camerata, 34.5; Dalmanella clarki, Rhipidomella emarginata?, 33.5............

Limestone, massive, coarsely crystalline. Cladopora rectilineata, Halysites catenulatus (a), Aulopora sp., Favosites sp., stromatoporoids............ Limestone, thin bedded ( 1 to 6 6 inches), crystalline, light gray....................... grained, light gray...........

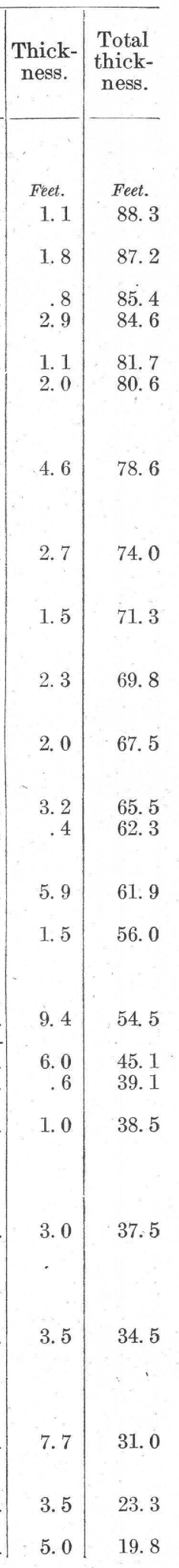


Section at Lincoln and Fifteenth streets, Tyrone-Contd.

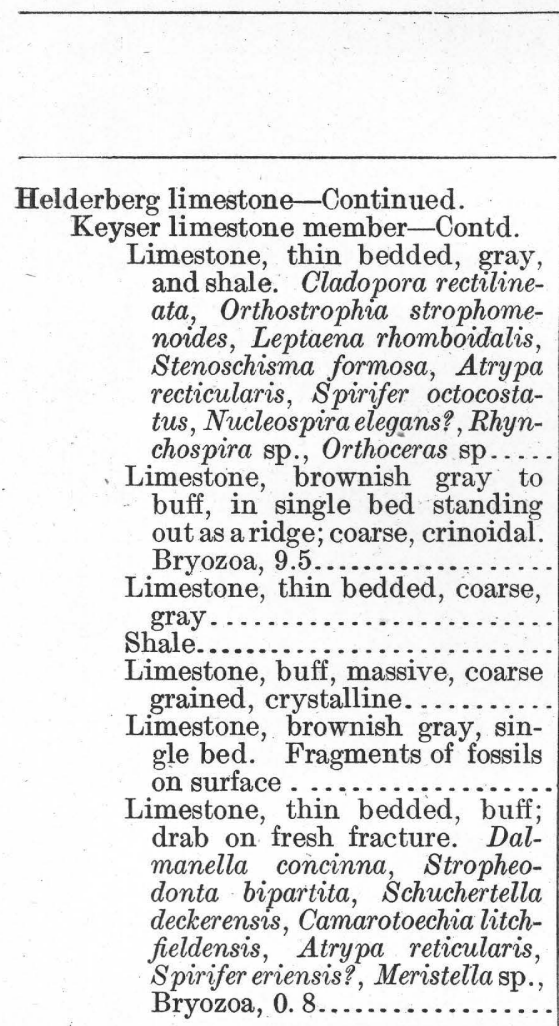

Tonoloway limestone:

Limestone, massive, buff.............

Limestone, massive, fine grained,

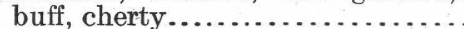

Limestone, massive, fine grained, buff, banded....................

Limestone, fissile, banded, buff; drab on fresh fracture................. Shale, buff, calcareous, contorted and in places apparently brecciated....

Shale, weathered, brown, earthy..... Limestone, massive, fine grained; weathered surface light gray, fresh fracture drab; banded; contains some thin chert lentils...............

Limestone, platy, banded, fine grained, light gray...............

Limestone, platy, laminated, fine grained, buff.' Leperditia. sp.,

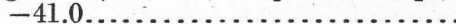

Limestone, buff to light brown, platy; much geodal calcite in small crystals..........................

Limestone, fissile, light gray.........

Concealed; probably platy limestone.

Limestone, light gray, platy, impure.

Limestone, light gray in solid bed; platy fracture....................

Limestone, platy, fine grained, buff. .

Concealed; brown shale in part.....

Limestone, platy, buff...............

Shale, calcareous, and fine siliceous oolite(?); weathered surface ferruginous, brown; bedding irregular.

Limestone, blocky, fine grained, buff.

Shale, weathered brown.............
Section at Lincoln and Fifteenth streets, Tyrone-Contd.

\begin{tabular}{|r|r}
$\begin{array}{c}\text { Thick- } \\
\text { ness. }\end{array}$ & $\begin{array}{c}\text { Total } \\
\text { thick- } \\
\text { ness. }\end{array}$ \\
\hline & \\
& \\
& \\
Feet. & Feet \\
1.5 & 14.8 \\
& \\
3.9 & 13.3 \\
.6 & 9.4 \\
.4 & 8.8 \\
3.6 & 8.4 \\
2.5 & 5.8
\end{tabular}

\begin{tabular}{|c|c|c|}
\hline & $\begin{array}{l}\text { Thick- } \\
\text { ness. }\end{array}$ & $\begin{array}{l}\text { Total } \\
\text { thick- } \\
\text { ness. }\end{array}$ \\
\hline 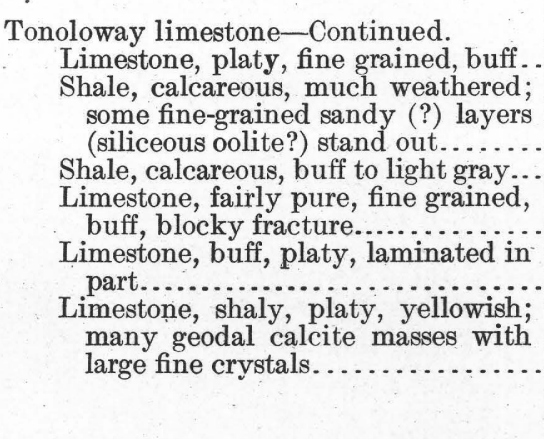 & $\begin{array}{r}\text { Feet. } \\
2.3 \\
\\
10.3 \\
1.5 \\
4.0 \\
6.3\end{array}$ & $\begin{array}{r}\text { Feet. } \\
-82.1 \\
-92.4 \\
-93.9 \\
-97.9 \\
-104.2\end{array}$ \\
\hline
\end{tabular}

This section is noteworthy in several respects. The lithology of the Tonoloway portion is unlike that of any other save the adjacent Pennsylvania Avenue section. It resembles, in the light color and fine texture, parts of the Wills Creek of Maryland rather than the Tonoloway. There is not sufficient ground for referring the beds to the Wills Creek, however, for they are almost barren of fossils (even Leperditia is very scarce), and it would be necessary to assume a hiatus, for which there is little evidence. The Chonetes jerseyensis zone of the Keyser is well defined faunally, but the nodular character so prominent elsewhere is lacking here. The presence of an abundance of corals and stromatoporoids, notably Cladopora rectilineata and Halysites catenulatus, and the absence of the characteristic brachiopods of the Favosites zone-Rensselaeria, Meristella, Uncinulus, etc. - as well as of Tentaculites gyracanthus, are also remarkable features of this section.

PENNSYLVANIA AVENUE, TYRONE.

The section given below was measured at the north end of Pennsylvania Avenue, Tyrone, just north of the West Virginia Pulp \& Paper Co.'s plant. Its base is in a small quarry 200 feet northeast of the concrete bridge over Bald Eagle Creek, parallel to which the exposure extends westward to the road cut through it.

The rocks exposed comprise 325 feet of the Tonoloway, the entire Keyser, and the base of 2.4 -76.0 the Coeymans. The lower part of the Tonolo\begin{tabular}{ll|l}
1.3 & -77.3 & way exposure is much crumpled, and the thick- \\
2.5 & -79.8 & wa
\end{tabular} 
nesses given are therefore only approximate. The upper part of the Tonoloway and the overlying beds are overturned about $21^{\circ}$. There are no signs of faulting in the exposure itself, but the Keyser is repeated about 100 yards to the west by a concealed fault.

The Tonoloway-Keyser contact is exceedingly sharp. The light-colored barren beds referred to the Tonoloway are succeeded without any transition by a thin shale carrying Keyser fossils, and this in turn is succeeded by an impure gray "bastard" limestone containing many characteristic species. The lithology of the Tonoloway here, as in the adjacent section at Lincoln and Fifteenth streets, is unlike that in any of the other exposures studied by the writer. It resembles that of the Wills Creek of Maryland, but as assignment of the formation to the Wills Creek would necessitate the assumption of a large hiatus at the top, for which there is insufficient evidence, it is better to refer the beds to the Tonoloway in spite of their lithologic difference from the Tonoloway elsewhere.

The Keyser-Coeymans contact is likewise very sharp. The platy barren beds at the top of the Keyser are overlain immediately by the coarse siliceous fossiliferous limestone of the Coeymans.

Section at north end of Pennsylvania Avenue, Tyrone.

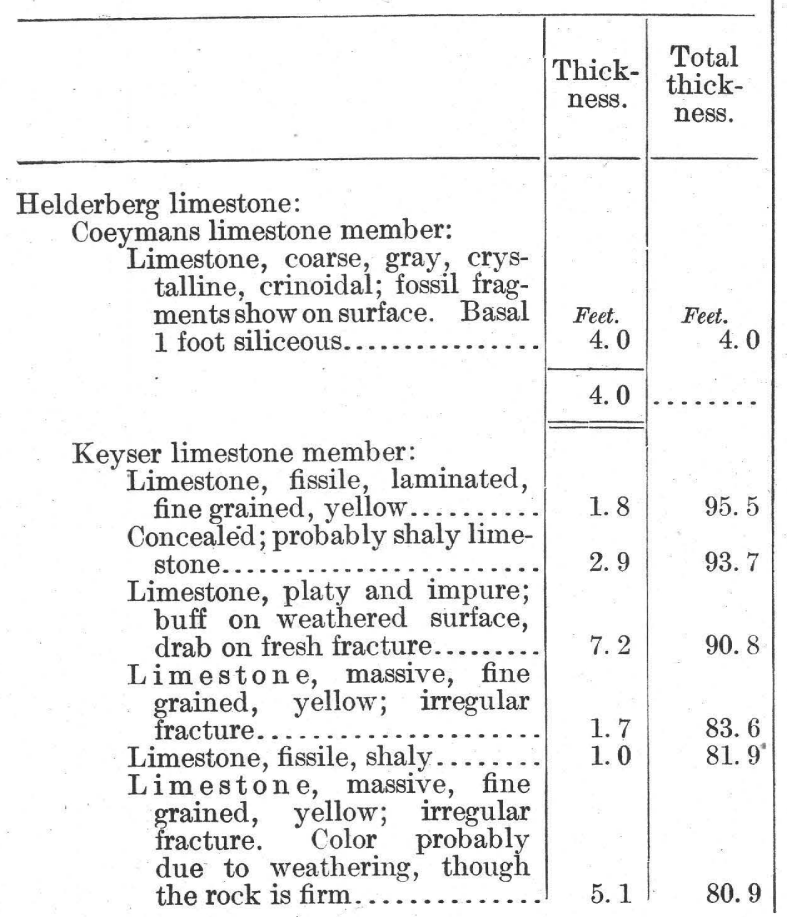

Section at north end of Pennsylvania Avenue, Tyrone-Con. .

Helderberg limestone-Continued. Keyser limestone member-Cont'd. Limestone, laminated, fissile; light gray on weathered surface, drab on fresh fracture... Limestone, relatively impure, platy; light gray to buff...... Limestone made up mainly of partly silicfied stromatoporoids......................

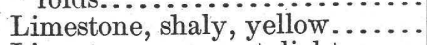

Limestone, compact, light gray; conchoidal fracture. Scattered stromatoporoids; Leperditia sp., 63.4.................

Limestone, impure, platy, buff.

Limestone, compact, fine grained, very light colored. Leperditia sp., 61.4..

Limestone, made up entirely of stromatoporoids and corals, mainly the former............

Limestone, impure, shaly, fine grained, light gray. Corals and stromatoporoids near base.

Limestone, fine grained, light gray to buff; conchoidal fracture. Unit partly concealed. Scattered corals and stromatoporoids; Favosites sp., Leperditia sp., 56.4; Leperditia sp., $54.0 \ldots \ldots \ldots \ldots \ldots \ldots . . . . . . .$.

Limestone, light gray to buff, fine grained, massive. Cross sections of Leperditia on weathered surface...........

Concealed; probably shale......

Limestone made up of stromatoporoids and corals. Cladopora rectilineata, 44.4...........

Limestone, light gray; almost entirely coral. Cyathophylloid corals, Favosites sp., Cladopora rectilineata, and stromatoporoids are very abundant; Rhynchospira sp., imestone in single bed, lioht

Limestone in single bed, light fracture. Pholidops ovata, Stropheodonta bipartita, Whitfieldella cf. $W$. nucleolata, Meristella sp.?, 26.4..........

Limestone, thin bedded ( 1 to 2 inches), fine grained, impure, weathered, light gray, Whit-

Limestone in two beds, coarse, crystalline, medium gray. Favosites sp., Stropheodonta

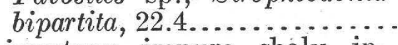

Limestone, impure, shaly, indistinctly nodular. Strophonella geniculata?, Schuchertella sp., Camarotoechia sp.?, Clado pora rectilineata, Stromatoporoidea, Bryozoa, 21.1; Whitfieldella cf. $W$. nucleolata, $18.9 \ldots \ldots \ldots \ldots . . . . . . .$. 
Section at north end of Pennsylvania Avenue, Tyrone-Con.

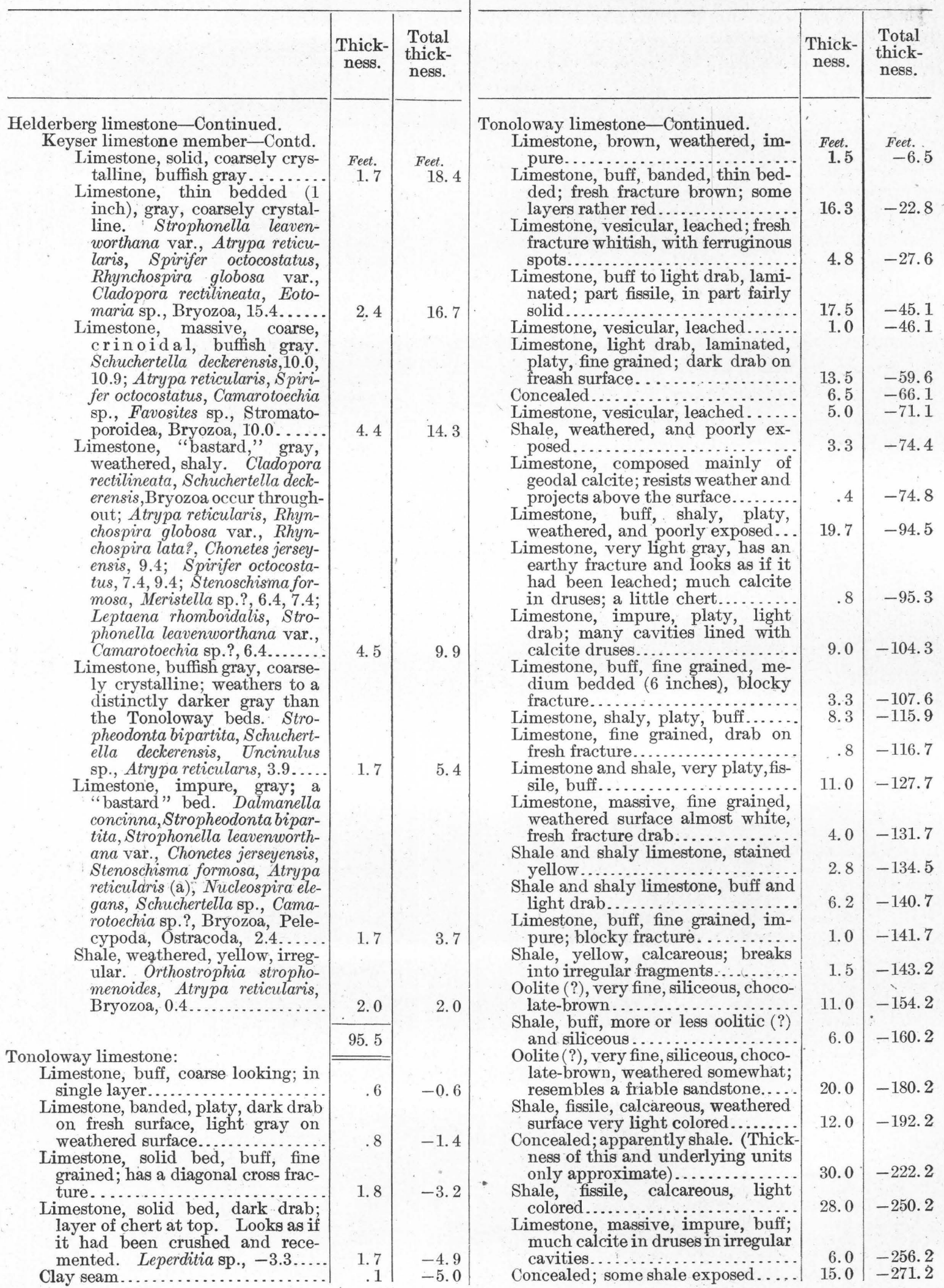


Section at north end of Pennsylvania Avenue, Tyrone-Con.

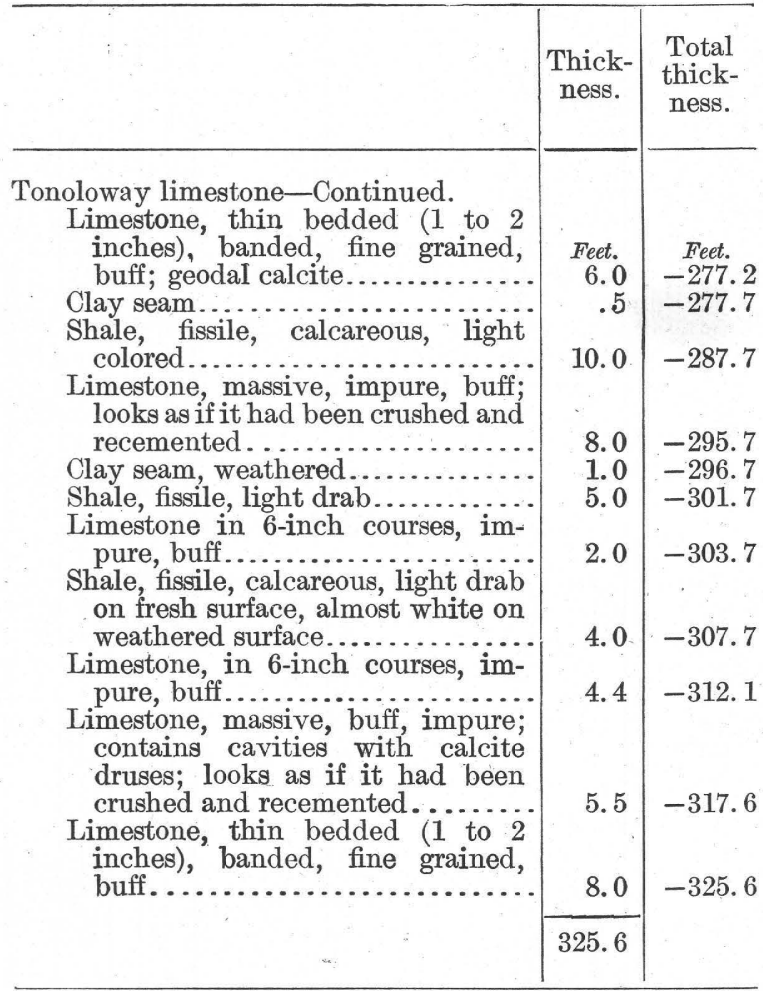

This section is remarkable for the barrenness and peculiar lithology of the Tonoloway and for the sharpness of the Tonoloway-Keyser contact. In the Keyser itself the fauna of the Chonetes jerseyensis zone is well developed, but the characteristic nodular beds are lacking. The presence of Cladopora rectilineata in considerable abundance in this lower zone is noteworthy. The characteristic brachiopods of the Favosites zone and Tentaculites gyracanthus are not represented by even a single specimen. This zone, on the other hand, carries a profufusion of corals and stromatoporoids, and in this respect the section resembles no other section studied except that at Grovania.

\section{MAPLETON.}

A very good exposure of part of the Tonoloway and nearly all of the Keyser member of the Helderberg is to be seen in the quarry of I. N. Swope on the north bank of Juniata River directly opposite Mapleton (or Mapleton Depot): The Tonoloway at this place is characteristically developed and, in addition, contains several beds with fossils that suggest more normally marine conditions than those under which the rather barren facies occurring in most of the other sections studied were laid down. The Keyser has near its base a thick bed of pure crinoidal limestone, which is comparable to that exposed near Burnham, north of Lewistown. The contact of the Keyser and Coeymans was not seen at this locality.

The section was measured from the exposures directly north of the end of the bridge over the Juniata:

Section in Swope quarry, near Mapleton.

\begin{tabular}{l|c|c}
\hline & Thick- & $\begin{array}{c}\text { Total } \\
\text { ness. }\end{array}$ \\
ness.
\end{tabular}

Helderberg limestone (Keyser limestone member):

Concealed by talus, quarry waste, etc. Much of the talus of the upper part is ash-colored shale.

Limestone, light-gray; banded on weathered surfaces; fresh surface dark gray, fine grained, not banded; conchoidal fracture; 3inch courses separated by shale. Leperditia sp., 150, 149.1; Bryozoa, 148.1, 145.7; Tentaculites gyracanthus, Ostracoda (a), 148.1. Spirorbis laxus (a), 147.2; Whitfieldella cf. W. nucleolata, 145.7?,

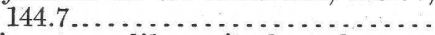

Limestone, like unit above but not in courses separated by shale; fairly massive. Pelecypoda,142.7.

Shale, calcareous, weathered, yellow.

Limestone, very light gray, compact, fine grained; dark on fresh surface; faintly banded................

Limestone, composed entirely of stromatoporoids. ..............

Shale, weathered yellow..........

Limestone, massive, light gray; composed of stromatoporoids . ........ Limestone nodules, large, in shale matrix...............................

Limestone, rather platy, shaly, dark gray. Stromatoporoids, 129.7;

Limestone, dark gray, conchoidal, impure, fine grained; in 2 to 12 inch courses, separated generally by thin shale laminae. Pholidops ovata, 121.7, 109.7; Rensselaeria mutabilis, Rensselaeria keyserensis, 121.7; Spirifer vanuxemi var. prognosticus, 121.7-108. 7; Uncinulus nucleolatus (a), 119.7-108.7; Leperditia sp., 118.7, 108.7; Pelecypoda, 117.2 (a), 109.7 (c); Ostracoda, 113.7, 108.7; Gypidula coeymanensis prognostica, 109. 7......

Shale, calcareous, containing large nodules (diameter 5-6 inches) of limestone and one or two beds of fine-grained conchoidal blue limestone. Uncinulus nucleolatus throughout; Aulopora sp., 106.7, 104.7 (c); Stromatoporoidea, Bryozoa, 106.7 (a), 102.7; Pholidops ovata, 106.7; Favosites sp., 104.7 (c), 102.7; Schuchertella interstriata?, Pelecypoda, Ostracoda 104.7 (a); Spirorbis laxus, Meristella praenuntia, 102.7.......... \begin{tabular}{r|r} 
Feet. & Feet. \\
9.0 & 153.1 \\
4.8 & 144.1 \\
.9 & 139.3 \\
& \\
2.8 & 138.4 \\
.9 & 135.6 \\
.8 & 134.7 \\
3.0 & 133.9 \\
.8 & 130.9
\end{tabular}

4.3

130.1

19.1

125.8 


\begin{tabular}{l}
\hline$+(1)$ \\
\hline
\end{tabular}

Helderberg limestone (Keyser limestone member-Continued.

Limestone, bluish gray, crystalline, single bed, fairly pure............

Limestone, very impure, earthy, dark gray; shaly fracture: Dalmanella concinna, Atrypa reticularis, $50.7 \ldots . . . . . . . . . . . . . .$.

Shale, fissile, calcareous; weathers a ferruginous brown; has some nodules near top. Bryozoa, Pholidops ovata, Dalmanella concinna, Dalmanella clarki, Leptaena rhomboidalis, Stropheodonta bipartita? Chonetes jerseyensis, Atrypa reticularis, Spirifer modestus plicatus, 49.2

Limestone, impure, nodular, dark, single bed. Orthostrophia strophomenoides?, Dalmanella concinna, Stenoschisma formosa, Atrypa reticularis (a) $48.7 \ldots . . . . . . . . . . .$.

Limestone, fairly pure, blue, crystalline; nodular character lacking on fresh surfaces and very indistinct on weathered surfaces; thin bedded (2 to 4 inches); a few 2inch chert nodules scattered near top. Atrypa reticularis, 41.2-46.7; Spirifer octocostatus, 46.7, 45.7; Orthostrophia strophomenoides, Dal manella concinna, Stropheodonta bipartita, Schuchertella deckerensis, 43.7; Camarotoechia litchfieldensis, 43.7; Crinoidea, Bryozoa, Pholidops ovata, Stenoschisma deckerensis, 41.2 .

Limestone, nodular, relatively impure, rather coarse grained and with considerable interlaminated shale; would be classed as a "bastard" limestone, but it is purer than the unit beneath. Dalmanella concinna, Dalmanella clarki, Stropheodonta bipartita, Chonetes jerseyensis, Atrypa reticularis, Platystoma niagarensis?, 39.7 .....................

Limestone, shaly, very nodular, "bastard," light gray and brown on weathered surfaces. Crinoidea, Stropheodonta bipartita, Chonetes jerseyensis, Atrypa reticularis, Spirifer octocostatus, Pelecypoda, throughout; Orthostrophia strophomenoides, 38.7; Dalmanella concinna, Nucleospira elegans, 38.7, 35.5; Rhipidomella emarginata?, 37.7; Leptaena rhomboidalis, Strophonella geniculata (c), Schuchertella deckerensis, Platystoma niagarensis?, 37.7, 35.5; Aulopora sp., Spirorbis sp., Bryozoa (a), Dalmanella clarki, Dalmanella cf. D. perelegans, Schuchertella interstriata?, Stenoschisma formosa (c), Stenoschisma deckerensis, Camarotoechia litchfieldensis, Rhynchospira globosa, Nucleospira ventricosa, Orthoceras sp., Calymene camerata, 35.5. . s...............

\begin{tabular}{|r|r}
$\begin{array}{r}\text { Thick- } \\
\text { ness. }\end{array}$ & $\begin{array}{r}\text { Total } \\
\text { thick- } \\
\text { ness. }\end{array}$ \\
\hline & \\
$\begin{array}{r}\text { Feet. } \\
2.8\end{array}$ & $\begin{array}{r}\text { Feet. } \\
54.1\end{array}$ \\
1.5 & 51.3 \\
& \\
& \\
1.0 & 49.8 \\
& \\
& \\
& \\
& \\
& \\
& \\
&
\end{tabular}




\begin{tabular}{l}
\hline \\
Helderberg limestone (Keyser limestone \\
member) -Continued. \\
Limestone, coarsely crystalline, \\
light gray, very pure (98 per cent \\
CaCO 3 ), extremely massive and \\
crinoidal. Bryozoa, $32.3,9.4$ (a); \\
Pholidops ovata, Leptaena rhom- \\
boidalis, Camarotoechia sp., Proetus \\
pachydermatus, 32.3; Stropheodonta \\
bipartita, 24.7; Schuchertella sp., \\
Meristella sp., 19.4; Sphaerocys- \\
tites multifasciatus, Dalmanella \\
clarki, Stenoschisma formosa (c), \\
Camarotoechia litchfieldensis (a), \\
Atrypa reticularis (c), Rhyncho- \\
spira globosa var. (a), Rhyncho- \\
spira formosa, 9.4............ \\
Limestone, thin bedded (2 to 3 \\
inches), dark gray, fine grained, \\
distinctly nodular............... \\
Limestone, somewhat nodular but \\
yet massive, dark gray, fine \\
grained. Leperditia sp., $2.7 . . . . .$. \\
\end{tabular}

Tonoloway limestone:

Limestone, medium bedded (4 to 12 inches), pure, dark gray, not banded; shale between the courses. Leperditia sp. through-

Limestone, thin bedded (3 to 6 inches), pure, dark gray, fine grained; banded and light gray on weathered surface...........

Shale, calcareous.................

Limestone, massive, dark gray, fine grained, pure; conchoidal fracture; in places shows a 1-inch bedding. Leperditia sp. throughout........................

Limestone, light gray, in 3 -inch courses with shale between......

Limestone, massive bed, very light gray, fine grained; conchoidal fracture. In this unit there has been dissolved out a good-sized cave reaching down to an unknown depth. The limestone seems very pure and has small scattered masses of crystalline calcite. Leperditia sp., -15.4,

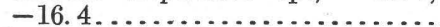

Limestone, banded, thin bedded ( 2 inches) but not fissile, light gray, pure. Leperditia sp., -20.8 .

Travertine................................ light gray. Leperditia sp., -26.3

Limestone, very platy, fissile; weathered surfaces have a faint greenish tinge.................

Limestone, rather irregular, heavy bed, fine grained, light gray, pure.......................

Limestone, very platy, fissile, light gray, fine grained; seems fairly pure. Leperditia sp. (a), -33.2 ...

Limestone, dark gray, with a 4inch layer of chert at center......

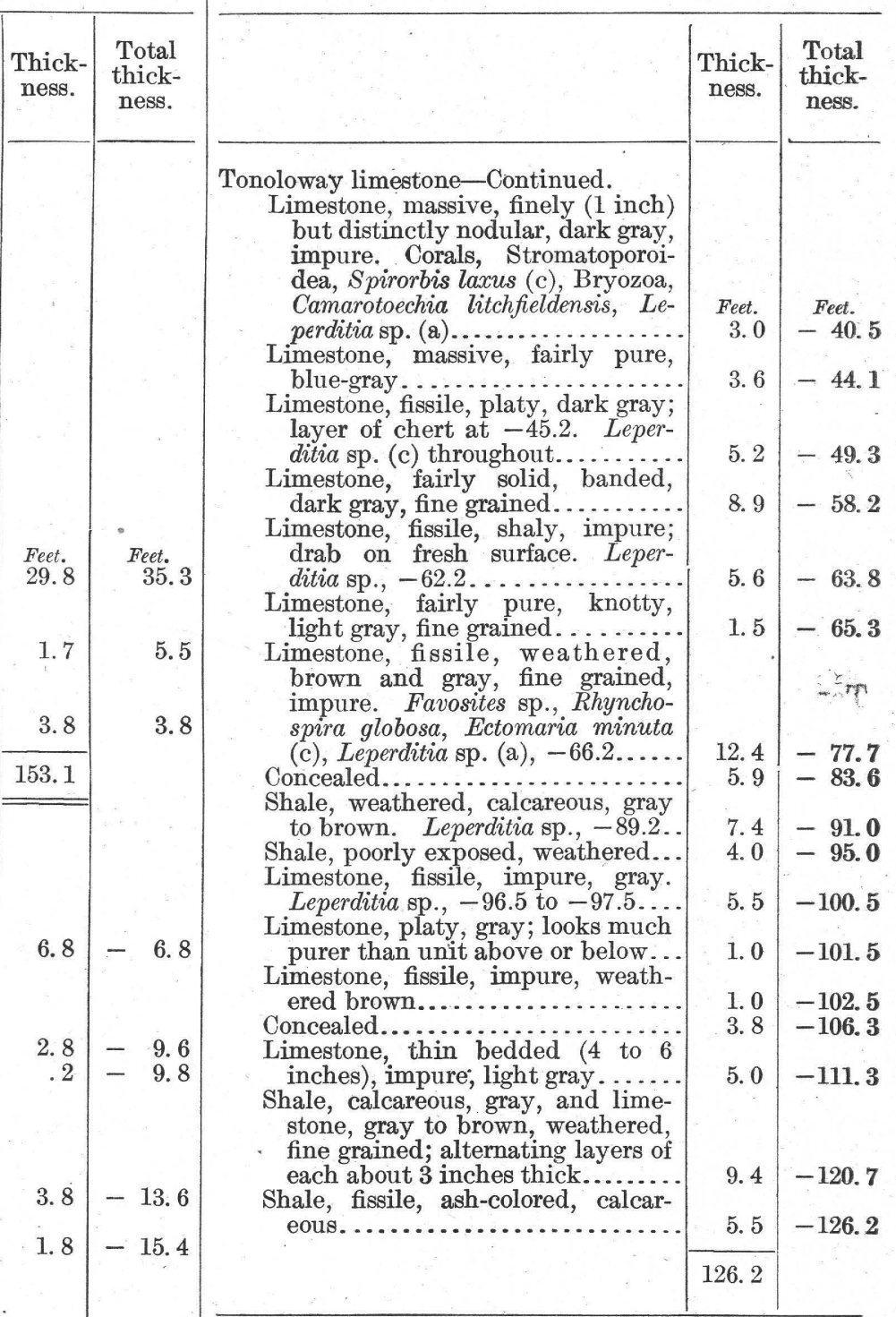

The Mapleton section is noteworthy because it contains several zones of the Tonoloway of a more normally marine facies than was observed in any other section studied. In this feature it resembles parts of the Maryland Tonoloway that carry a relatively large marine fauna. The thick crinoidal unit near the base of the Chonetes jerseyensis zone of the

$3.6-29.0$ Keyser is also notable. The Favosites zone of the Keyser contains a subzone with Cladopora $2.6-31.6$ rectilineata and other corals at about the horizon of the profuse coralline development at $1.2-32.8$ Tyrone and Grovania. As in those sections also, 3.4 it has a Stromatopora reef well up in the Keyser $3.4-36.2$ and shows a rarity of such forms as Rensselaeria $1.3-37.5$ mutabilis, Meristella praenuntia, and Tentacu- 
lites gyracanthus. The abundance of Uncinulus nucleolatus in the Favosites zone is not paralleled in any other section studied.

\section{MOUNT ROCK, LEWISTOWN.}

The section given below begins just across the Kishacoquillas Pike from the Spanogle \& Yeager Co.'s flour mill at Mount Rock and extends southward along the pike past the west end of the bridge over Kishacoquillas Creek. It lies about 100 yards south of the Lewistown \& Readsville Railway Co.'s power house and car barn.

E. V. d'Invilliers, ${ }^{1}$ describing the geology of Derry Township, Mifflin County, refers to this section very briefly. He gives the thickness of the limestone and lime shales of the Lewistown exposed here as 350 feet and mentions several massive beds.

The lowest exposures reveal the top of the Tonoloway. Above these a large part of the Keyser member of the Helderberg is to be seen, though the uppermost part of the Keyser is concealed. The Coeymans, New Scotland, and Oriskany are well developed. The section given below extends from the lowest exposure up into the new Scotland. It is probable that part of the beds overlying those definitely known to be New Scotland are also of that age, but the data at hand are insufficient to determine the position of the New Scotland-Oriskany contact.

Section on Kishacoquillas Pike at Mount Rock, Lewistown.

\begin{tabular}{|c|c|c|}
\hline . & $\begin{array}{c}\text { Thick- } \\
\text { ness. }\end{array}$ & $\begin{array}{l}\text { Total } \\
\text { thick- } \\
\text { ness. }\end{array}$ \\
\hline 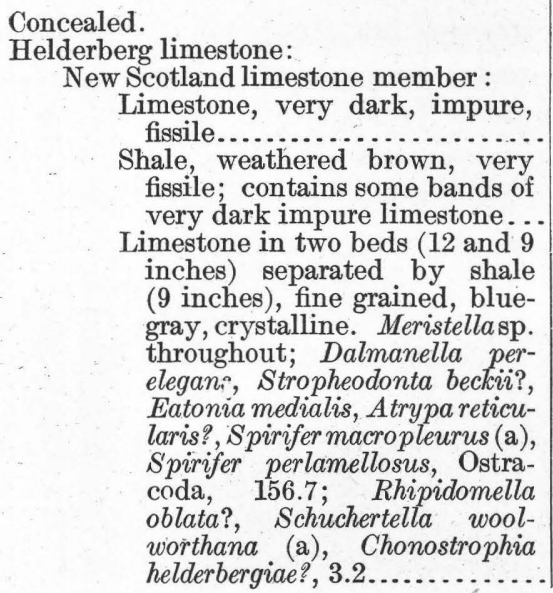 & $\begin{array}{c}\text { Feet. } \\
3.0 \\
10.4\end{array}$ & $\begin{array}{l}\text { Feet. } \\
18.5 \\
15.5\end{array}$ \\
\hline
\end{tabular}

Section on Kishacoquillas Pike at Mount Rock, LewistownContinued.

\begin{tabular}{c}
\hline \\
Helderberg limestone-Continued. \\
New Scotland limestone member- \\
Continued. \\
Limestone, single bed, light gray, \\
cherty, fine grained; some cal- \\
calcite cleavage faces show; \\
does not scratch hammer. \\
Bryozoa, Dalmanella perele- \\
gans, Stropheodonta planulata, \\
Camarotoechia sp., Eatonia \\
medialis, 2.5................
\end{tabular}

\section{Coeymans limestone member:}

Shale, weathered, brown.........

Limestone, single bed, light gray, cherty. Stropheodonta arata, Schuchertella sp., Gypidula. coeymanensis, Atrypa reticularis, Meristella sp., $8.2 \ldots \ldots$.

Shale, weathered, dark gray, calcareous; limestone bands and large nodules. Lingula sp., Leptaena rhomboidalis, Stropheodonta planulata?, Schuchertella woolworthana, Chonetes cf. C. hemisphericus, Pelecypoda, Orthoceras sp., Ostracoda (a), 7.3............

Limestone, massive, sandy, crystalline, blue; some black chert nodules; very tough, hard rock. Dalmanella perelegans?, Leptaena rhomboidalis, Gypidula coeymanensis, Atrypa reticularis, Pelecypoda, 5.3; Camarotoechia sp.?, Spirifer cyclopteris, 5.3, 2.0; Stropheodonta arata, 2.8; Bryozoa, Pholidops ovata, Rhipidomella oblata?, Strophonella leavenworthana (c), Phacops logani, Dalmanites sp., 2.0..........

,

\begin{tabular}{|r|r}
$\begin{array}{r}\text { Thick- } \\
\text { ness. }\end{array}$ & $\begin{array}{r}\text { Total } \\
\text { thick- } \\
\text { ness. }\end{array}$ \\
\hline & \\
& \\
Feet. & Feet. \\
2.6 & 2.6 \\
\hline 18.5 & \\
\hline \hline .6 & 10.6 \\
& \\
& \\
2.3 & 10.0
\end{tabular}

Keyser limestone member:

Limestone, dark gray, fine grained, thin bedded. Leper-

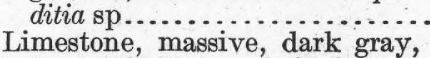
fine grained; conchoidal fracture......................... weathered...................

Limestone, massive, dark gray, impure, fine grained; conchoidal fracture..............

Shale, weathered.............

Limestone, light gray, solid, fine grained; conchoidal fracture...

Limestone, platy, dark gray, impure $\ldots . . . . . . . . . . . . . . .$.

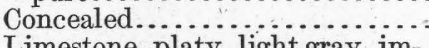

Limestone, platy, light gray, impure, fine grained; conchoidal

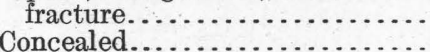

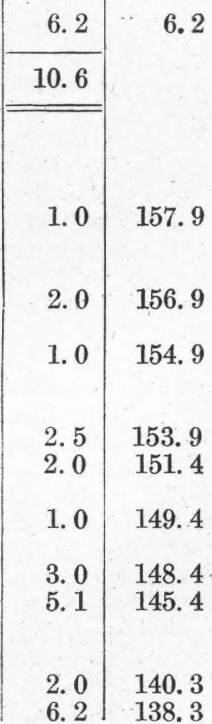


Section on Kishacoquillas Pike at Mount Rock, LewistownContinued.
Helderberg limestone-Continued. Keyser limestone member-Contd.

Limestone, impure, platy, yellow; weathered much and poorly exposed.

Limestone, platy, impure, weathered, yellowish, Meristella sp..

Limestone, massive, light gray; conchoidal fracture.

Limestone, thin bedded (2 inches), dark gray; conchoidal

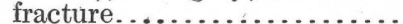

Concealed. Dalmanella sp., Schuchertella prolifica, Rensselaeria keyserensis, Meristella praenuntia?, Hormotoma sp., Bryozoa loose on surface......

Limestone, banded; conchoidal fracture. Meristella sp.?, Tentaculites gyracanthus, 105.2 . . .

Concealed.....................

Limfestone, very impure. Tentaculites gyracanthus, Rensselaeria mutabilis, Bryozoa, Pelecypoda, 103.2

Limestone, thin bedded, fine grained, dark gray, impure, poorly exposed. Pholidops ovata, Rensselaeria obtusa, Pelecypoda, throughout; Bryozoa, Schuchertella interstriata?, Rensselaeria mutabilis, Tentaculites gyracanthus, Orthoceras cf. $O$. pauciseptum, Ostracoda, 101.2; Camarotoechia sp.?, Meristella sp.?, 99.2.

Limestone, impure, dark gray thin bedded, fine grained. Bryozoa, Pelecypoda, throughout; Rensselaeria keyserensis (a) 97.7; Tentaculites gyracanthus, 96.2, 97.7; Dalmanella sp., Schuchertella prolifica, Uncinulus keyserensis (c), 96.2; Rensselaeria (Beachia) proavita, 95.2, 96.2; Meristella sp.?, 96.2....

Concealed. Bryozoa (c), Pholidops ovata, Rensselaeria obtusa?, Meristella sp.?, Pelecypoda, loose on surface.........

Limestone, very shaly, with purer fine grained light-gray bands. Spirifer vanuxemi prognosticus, Pelecypodia, throughout; Uncinulus keyserensis, Dalmanella concinna, Meristella sp.?, 87.2; Pholidops ovata, Stenoschisma formosa? Rensselaeria (Beachia) proavita, Ostracoda, 86.2.

Limestone, very coarsely nodular (4 to 6 inches), light blue-gray; conchoidal fracture. Shale between nodules. Spirifer vanuxemi prognosticus throughout; Camarotoechia litchfieldensis, Rensselaeria mutabilis, Pelecypoda, 84.2; Uncinulus keyserensis, $82.2 ; 83.2$; Rensselaeria keyserensis, 82.2
Section on Kishacoquillas Pike at Mount Rock, LewistownContinued.

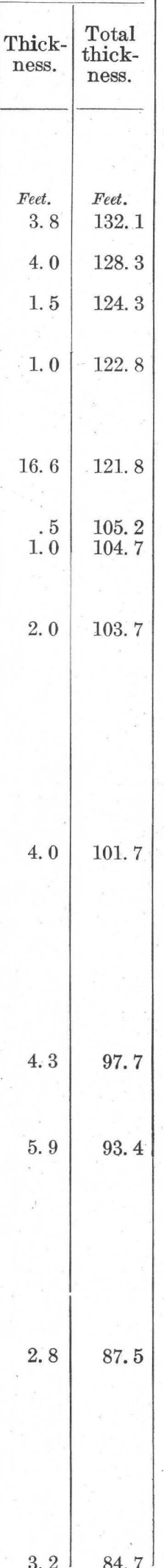

Helderberg limestone-Continued.

Keyser limestone member-Contd.

Limestone, thin bedded, bluegray, crystalline. Spirifer vanuxemi prognosticus, $80.2,81.2$; Pholidops ovata, 80.2; Camarotechialitchfieldensis, Rensselaeria mutabilis, Pelecypoda, 79.2 ....

Limestone, massive; in part light blue-gray, fine grained; in part subcrystalline. Bryozoa, Dalmanella sp., Pelecypoda, 78.2.

Limestone, thin bedded ( 2 to 6 inches), fine grained, light bluish gray; conchoidal fracture. Atrypa reticularis, $\mathrm{Ca}$ marotoechia, sp., throughout; Pholidops ovata (a), Dalmanella concinna, Merista typa,

Ostracoda, $75.2 \ldots \ldots \ldots \ldots \ldots \ldots . . . \ldots$.
Limestone, impure, shaly, alternating with harder layers, each in about 6-inch courses. Pholidops ovata, Rensselaeria mutabilis (a), 68.2..........

Concealed...................

Limestone, shaly, impure, with hard layers of more resistant rock. Dalmanella concinna, Leptæna rhomboidalis, Stropheodonta bipartita, Camarotoechia litchfieldensis, Atrypa reticularis, Spirifer vanuxemi prognosticus, 60.7............

Limestone, dark gray, crystalline. Bryozoa, Stropheodonta bipartita, Rensselaeria mutabilis, Merista typa, Calymene

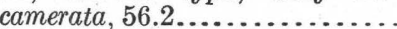

Limestone, thin bedded ( 1 to 6 inches), light blue-gray, fine grained, impure; has shale laminæ between the layers and several small lenses of brown weathered chert. Bryozoa, Leptaena rhomboidalis, Calymene camerata, 52.2, 54.7; Stropheodonta bipartita, 50.2 53.2 ; Spirifer vanuxemi, 53.2; Merista typa, 52.2; Schuchertella deckerensis 50.2

Limestone, massive, nodular, impure, dark gray. Bryozoa, 42.2-47.2; Leptaena rhomboidalis, Stropheodonta bipartita, Schuchertella interstriata?, Atrypa reticularis, 47.2; Dalmanella concinna, Stenoschisma formosa, Spirifer vanuxemi, Orthoceras sp., 45.2; Gypidula coeymanensis prognostica, 42.2; Merista typa, $41.2 \ldots \ldots \ldots \ldots \ldots \ldots$.

Limestone, massive, dark gray, impure, not very nodular. Orthostrophia strophomenoides, Stenoschisma formosa (c), Spirifer octocostatus, Merista typa, 40.2; Gypidula coeymanensis var. prognosticus (a), Atrypa reticularis, 38.2, 40.2; Bryozoa, 37.2................

\begin{tabular}{|c|c}
$\begin{array}{c}\text { Thick- } \\
\text { ness. }\end{array}$ & $\begin{array}{c}\text { Total } \\
\text { thick- } \\
\text { ness. }\end{array}$ \\
\hline & \\
& \\
Feet. & Feet. \\
2.9 & 81.5 \\
& \\
2.4 & 78.6
\end{tabular}


Section on Kishacoquillas Pike at Mount Rock, LewistownContinued.

Helderberg limestone-Continued. Keyser limestone member-Contd. Shale, weathered, yellow........

Iimestone, very nodular, impure, shaly, gray; many of its fossils are silicified. Atrypa reticularis throughout; Pelecypoda, 35.2; Bryozoa, Dalmanella concinna, Strophonella leavenworthana var., $34.2 \ldots . .$. .

Limestone, massive, somewhat nodular, dark gray, subcrystalline, impure. Gypidula prognostica (a) throughout. Schuchertella swartzi?, Atrypa reticularis, 33.2; Dalmanella clarki?, Rhipidomella emarginata?, Leptaena rhomboidalis, Strophonella geniculata, Chonetes jerseyensis (c), Stenoschisma deckerensis (a), Rensselaeria mutabilis?, Nucleospira ventricosa, Goldius barrandi, Cyphaspis cf. C. minuscula, Calymene camerata, Ostracoda, Pelecypoda, 31.2 ......................

Limestone, very nodular, impure, dark gray, weathered.... Limestone, massive, not nodular, dark gray, coarsely crystalline.

Limestone, nodular, impure, weathered; bastard limestone with occasional thin lenses of black chert. Ostracoda, 26.2

Limestone, crystalline, dark blue, thin bedded, with shaly laminae. Pelecypoda, 23.8.

Limestone, crystalline, dark blue, pure, massive, not nodular. Schuchertella deckerensis (c), Chonetes jerseyensis, Uncinulus sp., Atrypa reticularis, 21.9...................

Limestone, weathered, very nodular. Chonetes jerseyensis, Stenoschisma formosa, throughout; Dalmanella concinna, Stropheodonta bipartita, Meristella $\mathrm{sp} . ?, 17.2$...............

Limestone, massive, blue-gray, coarse, crystalline, crinoidal; weathers thin bedded in upper part. Camarotoechia sp., Rhynchospira sp., through-

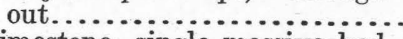

Limestone, single massive bed, pure, dark gray, coarsely crystalline and crinoidal in part; fine grained. and curly in other parts, which suggest slightly weathered Stromatopora. Spirifer vanuxemi, 1.9.............

Limestone, nodular, impure, weathered; crystalline on fresh fracture and blue-gray. Spirifer abundant on basal face...

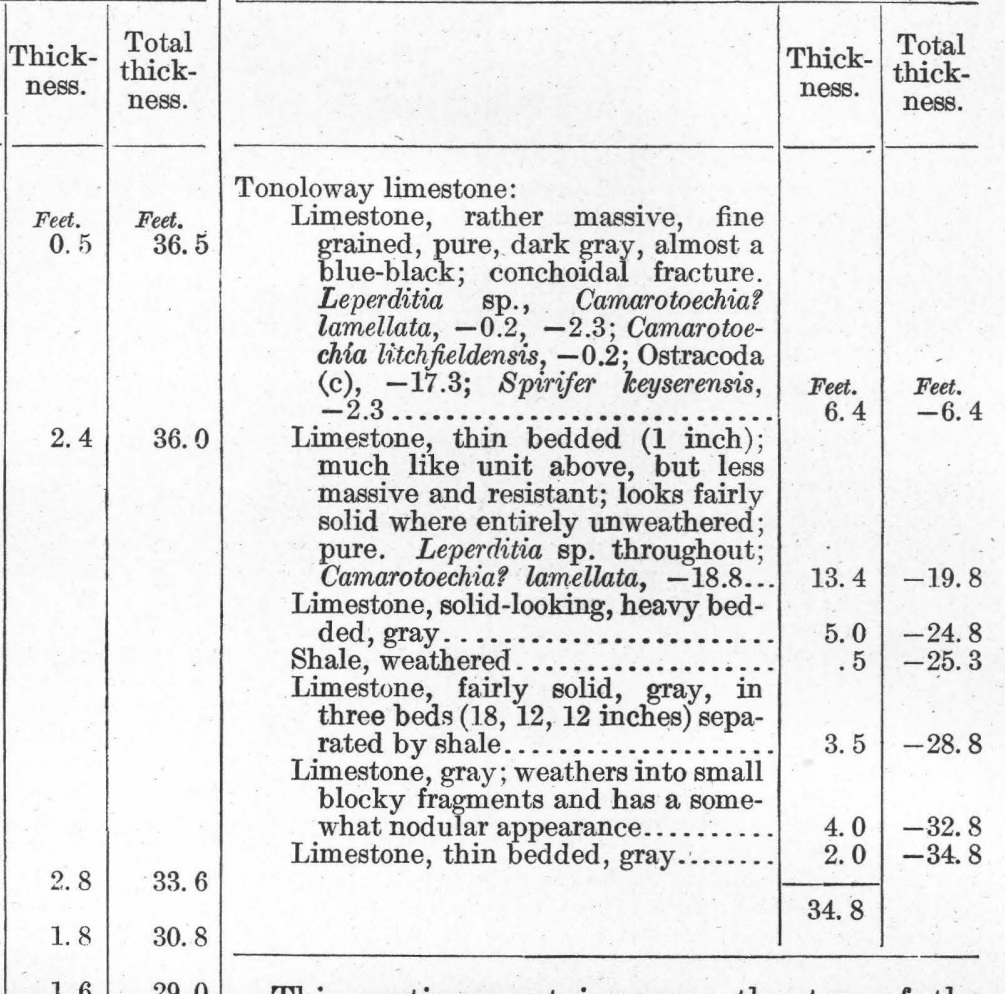

29.0 This section contains near the top of the Tonoloway formation the zone of Spirifer keyserensis which is present at the same horizon at Dalmatia and in Maryland. The lower part of the Keyser member is massive and crinoidal, resembling the heavy crinoidal bed at Mapleton. The zone of Gypidula coeymanensis var. prognosticus, so persistent and so well marked in Maryland, seems to be developed here, as at Selinsgrove Junction. The upper part of the Keyser is so poorly exposed as to render the identification of the fossil zones difficult, but the presence of the Leperditia subzone just beneath the Coeymans is a feature of interest.

CLARK'S MHLL, NORTHWEST OF NEW BLOOMFIELD.

The section given below lies along the Newport \& Sherman's Valley Railroad a short distance north of McKee station and about 2 miles northwest of New Bloomfield, the county seat of Perry County. The highest exposures are just opposite the old Clark's Mill.

The section was measured and studied in 1885 by E. W. Claypole, ${ }^{1}$ who divided it into 
the following: Black cherty limestone, 8 feet; Section at Clark's Mill, about 2 miles northwest of New Clark's Mill lime shales, 150 feet; Lewistown limestone, 100 feet. His Clark's Mill lime shales he correlated in a general way with the "Delthyris shaly limestone" and "Lower Pentamerus limestone" of New York-that is, with the Coeymans-New Scotland interval. The Lewistown he correlated with the "Waterlime" or "Tentaculite" limestone of New York.

This section was examined in 1913 by C. K. Swartz, ${ }^{1}$ who cited Claypole's measurements and recognized in the lower 103. feet the Tonoloway of Maryland and in the upper 150 feet the Keyser of Maryland.

In the following section the beds in the upper 140 feet comprise the entire Keyser member of the Helderberg and are apparently the same as those included by Claypole in his Clark's Mill lime shale. The beds in the lower 62 feet are equivalent to part of the Tonoloway of Maryland. The concealed interval immediately above the Keyser carries weathered Gypidula valves on its surface, and it is likely that the Coeymans member of the Helderberg is represented by part of this interval.

Section at Clark's Mill, about 2 miles northwest of New Bloomfield.

\begin{tabular}{|c|c|c|}
\hline & $\begin{array}{l}\text { Thick- } \\
\text { ness. }\end{array}$ & $\begin{array}{l}\text { Total } \\
\text { thick- } \\
\text { ness. }\end{array}$ \\
\hline 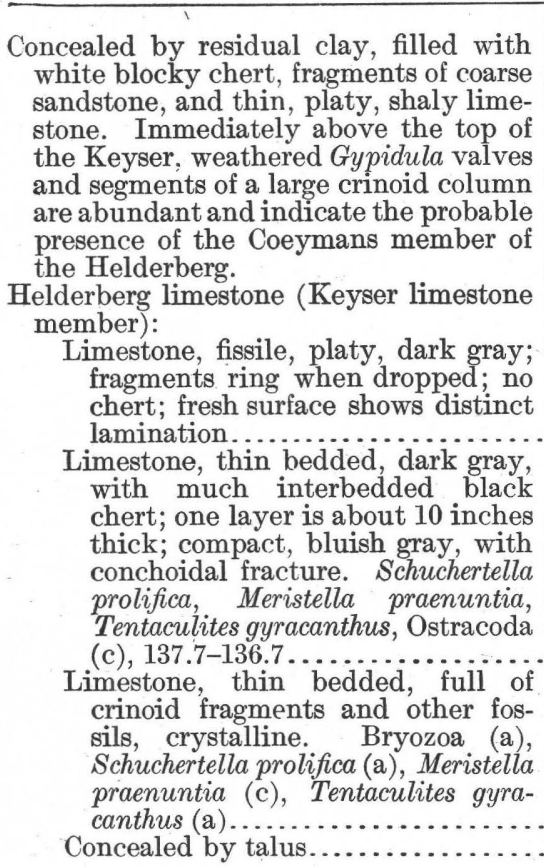 & $\begin{array}{l}\text { Feet. } \\
2.0\end{array}$ & $\begin{array}{l}\text { Feet. } \\
139.7\end{array}$ \\
\hline
\end{tabular}

Helderberg limestone (Keyser limestone member)-Continued

Limestone, thin bedded ( 1 to 3 inches), a little nodular, bluish gray; some of the layers are compact, with conchoidal fracture; others are subcrystalline, crinoidal and crammed with fossils; the unit, however, looks homogeneous. Meristella praenuntia, Tentaculites gyracanthus, Bryozoa, Ostracoda, Pelecypoda, throughout; Orbiculoidea sp., Camarotoechia sp., 127.1; Orbiculoidea discus (a), 123.5; Pholidops ovata, 119.1-122.1; Orthoceras sp., 121.1; Whitfieldella cf. W. nucleolata, 113.6, 109.1..........

Limestone, thin bedded, blue, crinoidal, subcrystalline, and crammed with fossil fragments. Bryozoa, Dalmanella clarki, Camarotoechia sp., Whitfieldella cf. W. nucleolata, Meristella praenuntia, Tentaculites gyracanthus.......

Concealed......................... cinulus keyserensis?, Uncinulus gordoni, Uncinulus nucleolatus, Whitfieldella cf. W. nucleolata, Or-

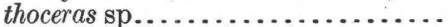

Concealed. Lingula sp., Orbiculoidea sp., Pholidops ovata, Dalmanella concinna?, Dalmanella clarki (c), Schuchertella prolifica, Schuchertella swartzi, Camarotoechia litchfieldensis, Uncinulus nuceolatus, Uncinulus keyserensis, Rensselaeria keyserensis (a), Rensselaeria obtusa (a), Beachia proavita, Spirifer vanuxemi prognosticus, Rhynchospira sp., Nucleospira ventricosa?, Meristella praenuntia, Tentaculites gyracanthus, Orthoceras sp., Favosites sp., Spirorbis sp., Bryozoa, Pelecypoda, Ostracoda, loose on the surface.................

Limestone, gray, crammed with a ramose bryozoan, Uncinulus nucleolatus, Uncinulus keyserensis, Spirifer vanuxemi prognosticus,

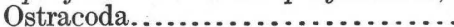

Concealed...........................

Limestone, compact, hard, bluish.

Pholidops ovata, Camarotoechia litchfieldensis, Ostracoda (a)......... Concealed. Bryozoa, Pholidops ovata (c), Dalmanella concinna, Dalmanella clarki, Leptaena rhomboidalis, Stropheodonta bipartita (a), Schuchertella swartzi, Camarotoechia litchfieldensis, Uncinulus keyserensis, Uncinulus mutabilis, Atrypa reticularis (a), Spirifer octocostatus, Spirifer vanuxemi var. prognosticus (a), Whitfieldella cf. W. nucleolata, Meristella sp. Coelidium pennsylvanicum, Holopea antiqua?, Cyclonema sp., Tentaculites gyracanthus, Orthoceras sp., Calymene camerata, Ostracoda (a), loose on the surface...................... 27.6

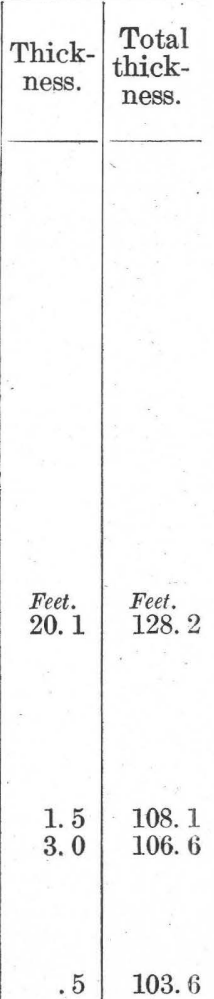


Section at Clark's Mill, about 2 miles northwest of New Section at Clark's Mill, about 2 milas northwest of New Bloomfield-Continued.

Helderberg limestone (Keyser limestone member)-Continued.

Limestone, thin bedded, dense, bluish; conchoidal fracture. Bryozoa, Ostracoda, throughout; Dalmanella concinna, Leptæna rhomboidalis, 67.3-66.4; Stropheodonta bipartita, Schuchertella prolifica?, Uncinulus keyserensis, Spirifer vanuxemi prognosticus, Calymene camerata, 66.4 ..................

Concealed. Favosites sp. Stromatoporoidea, Bryozoa, Dalmanella concinna, Leptaena rhomboidalis, Strophonella geniculata?, Strophonella leavenworthana var., Uncinulus keyserensis, Spirifer vanuxemi prognosticus, loose on the

surface.............................. ular. Favosites sp., Chonetes jerseyensis, throughout; Dalmanella sp., Schuchertella deckerensis (a), Stenoschisma formosa, Camarotoechia litchfieldensis (c), Spirifer modestus, Pelecypoda, Ostracoda,

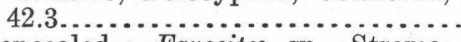

Concealed. Favosites sp., Stromatoporoidea, Chonetes jerseyensis, Meristella prænuntia, Calymene camerata, loose on the surface......

Limestone, very thin bedded, nodular, dark gray. Camarotoechia litchfieldensis, 32.6, 31.6; Ostra-

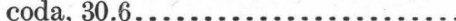

Concealed. Ectomaria minuta, Hormotoma sp., loose on the surface...

Limestone, thin bedded, much weathered and stained; débris full of fossils. Sphaerocystites multifasciatus, 24.5?, 26.5; Camarotoechia?, lamellata, Stromatoporoi dea, Stenoschisma formosa, Camarotoechia litchfieldensis, Spirifer modestus, Spirifer modestus var. plicatus?, Rhynchospira globosa (a), Leperditia sp. (a), loose on the surface.........................

Limestone, thin bedded, rather nodular, dark gray; upper 3 feet heavier bedded. Whitfieldella $\mathrm{cf}$. W. nucleolata, 20.5; Ectomaria minuta, 20.5?, 17.5; Leperditia sp., 20.5, 17.5, 13.9 (a); Ostracoda, 17.5.

Concealed interval.................

Limestone, thin bedded, very nodular, bluish gray. Camarotoechia? lamellata, 6.6, 5.6; Spirifer vanuxemi, 6.6; Rhynchospira globosa, 6.6, 4.6; Leperditia sp., 6.6-3.6; Rhynchospira sp., 5.6; Ostracoda, 5.6 (a), $3.6 \ldots \ldots \ldots \ldots \ldots \ldots \ldots$

Limestone, single heavy bed, compact, dark gray

Tonoloway limestone:

Limestone, rather massive, dark gray, not nodular. Leperditia sp., -1.5 . Bloomfield-Continued.

Tonoloway limestone-Continued.

Limestone, fissile, platy, yellowish, banded; fossils very rare; very different from overlying beds; gives a shingle-like talus; dark gray on fresh fracture....................

Limestone, single bed, dark gray. Leperditia sp., -8.9 to -9.9 .......

Limestone, dark gray, separated into 1-inch courses by silicified seams 1 inch thick, which stand out a little in relief. Leperditia sp.,

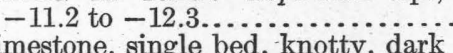

Limestone, single bed, knotty, dark gray; weathers into laminæ.......

Limestone, platy, shaly; weathers into plates.......................

Shale, contorted, yellow, partly con-

Limestone, knotty, irregular, yet massive......................

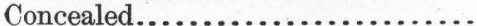

Limestone, very thin bedded, platy,

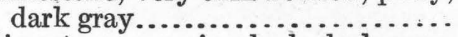

Limestone, massive bed, dark gray; breaks into thin plates.

Concealed.

Limestone massive, dark breaks into thin plates. Leperditia sp., -56.3 .

Concealed below.

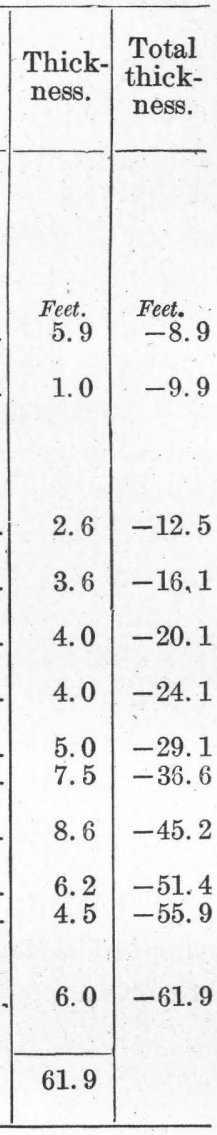

33.7

29.5

6.0

\section{company.}

The section was studied by I. C. Whitie ${ }^{1}$ in 1883 and referred to by him as the Georgetown section. He recognized in it the Oriskany sandstones; the Stormville shale, 100 feet thick; the Stormville and Bastard limestones, with a combined thickness of 135 feet; the Bossardville beds, with a thickness of 115 feet; and, at the base, the Salina. The sub- 
joined section does not include any of White's Oriskany, the uppermost units, referred to the New Scotland, representing part of his Stormville shale. The beds forming the Coeymans and Keyser members of the Helderberg are his Stormville and Bastard limestones. The Tonoloway portion of the section is all included in his Bossardville.

The Tonoloway-Keyser contact is placed at the base of the nodular beds. The KeyserCoeymans contact is marked sharply by the very sandy limestone forming the Coeymans member. This limestone contains few fossils, but its stratigraphic position and its lithologic agreement with the Coeymans of other sections justify its reference to this member. At the Emrick \& Lebo quarry, 4 miles northeast of Dalmatia and about a quarter of a mile south of Mandata (Bull Run), this sandy limestone is about 6 feet thick and is overlain by shale carrying Spirifer macropleurus. The Coeymans-New Scotland contact is placed at the base of the concealed unit, which carries loose on its surface numerous New Scotland fossils.

Section 1 mile south of Dalmatia.

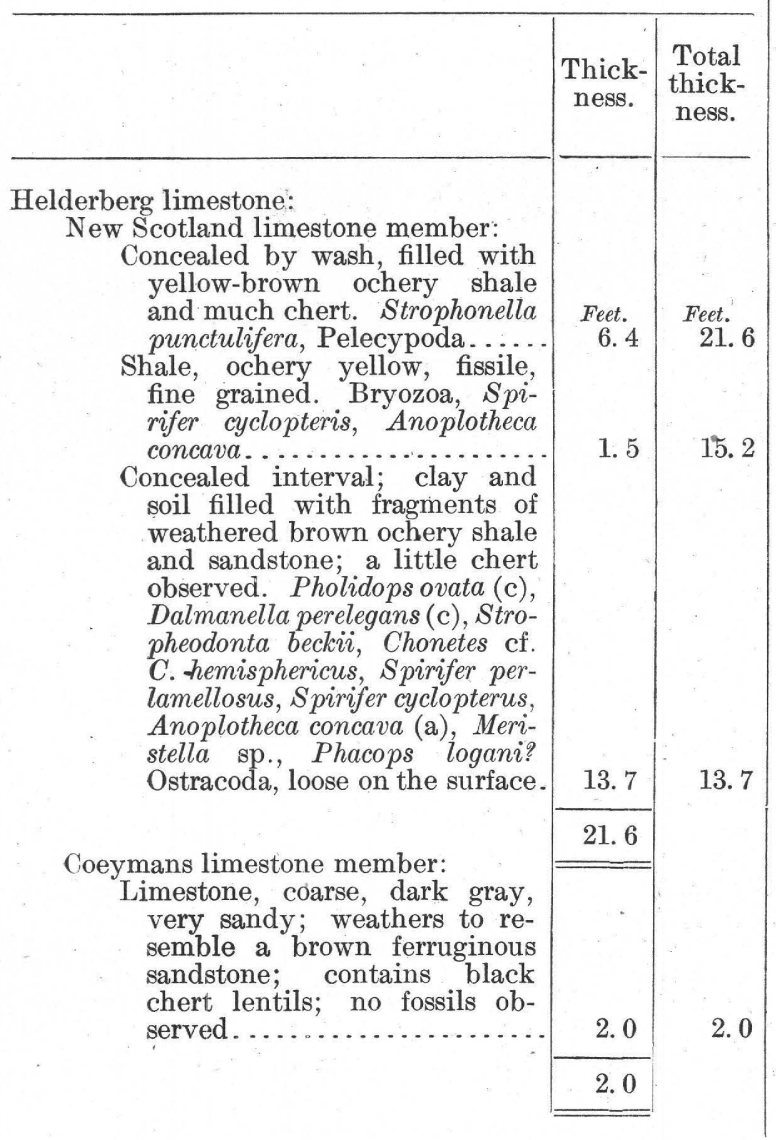

Section 1 mile south of Dalmatia-Continued.

He

Helderberg limestone-Continued.

Keyser limestone member-Contd.

Limestone, banded, fine grained, with conchoidal fracture, in 2 to 4 inch layers, separated by same thickness of weathered yellow shale; contains near top some large, irregular curly masses (18 inches in diameter), which look somewhat like Stromatopora.................

Limestone, blue-gray, conchoidal, fine grained, in four layers $(8,10,3,10$ inches $)$, separated by platy yellowish limestone...................... Limestone, banded, fine grained, weathered surface, light gray on fresh fracture; calcite seam at top................

Limestone, blue-gray, fine grained, conchoidal, thin bedded (6 inches); scattered lentils of black chert (1 inch thick and 18 inches long); calcite sheet at 118.6 and top................................

Limestone, bluish, fine grained;
conchoidal fracture; in thin layers (1 to 3 inches), with shale laminae between; calcite sheet at 111.6 and at top. Meristella sp., 107.6-116.6; Tentaculites gyracanthus, 106.1112.6; Pelecypoda, 106.1,

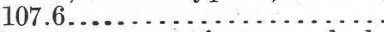

Limestone, very impure, dark, shaly; carries irregular lenses ( 2 to 3 inches in diameter) of pure bluish limestone; in bulk about half of each; weathers to a light-gray color; calcite seam near base and at top. Meristella praenuntia (a), 99.6-102.6; Pelecypoda, Tentaculites gyracanthus, 99.6-

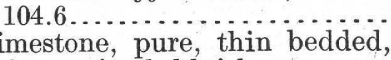

Limestone, pure, thin bedded,
fine grained, bluish gray; conchoidal fracture; some fossiliferous lenses. Meristella sp.,

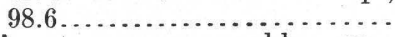

Limestone, coarse, blue-gray, crystalline, in irregular 2 to 3 inch layers with light-gray shale laminae between; calcite sheet near top. Uncinulus keyserensis, Meristella praenuntia, Tentaculites gyracanthus, and Pelecypoda throughout; Bryozoa, Camarotoechia litchfieldensis, Whitfieldella cf. $W$. nucleolata, 94.9..........

Limestone, shaly, weathered, impure, dark gray; contains a few pure crystalline streaks; calcite sheet near top. Meristella sp., Tentaculites gyracanthus, $93.6 \ldots . . . . . . . . . . . . . .$.
Feet. Feet.

10. 3139.8 
Helderberg limestone-Continued.

Keyser limestone member-Contd.

Limestone, coarse, crystalline, bluish gray, profusely fossiliferous. Uncinulus keyserensis? Meristella praenuntia (a), Tentaculites gyracanthus, Pelecypoda, Bryozoa, Ostracoda.

imestone, solid, impure, dark gray; weathers yellow; contains many streaks of pure finegrained limestone; calcite sheet at top. Whitfieldella? prosseri, Meristella praenuntia (a), Tentaculites gyracanthus (a), Orthoceras sp., Pelecypoda, 90.6

Limestone, coarse, crystalline, blue-gray; weathers light gray; profusely fossiliferous. Uncinulus keyserensis, Meristella praenuntia (c) throughout; Bryozoa, Atrypa rugosa?, Whitfieldella cf. W. nucleolata, Pelecypoda, 89.6; Uncinulus nucleolatus, Rensselaeria mutabilis (c), 88.6.

Limestone, impure, medium gray, fine grained; weathers brown and has a number of thin conchoidal purer lenses which weather light gray; calcite sheet at base; solid unit as a whole. Tentaculites gyracanthus throughout; Ostracoda, 85.6

Limestone, blue, crystalline in lenses 1 to 2 inches thick, with irregular shaly layers between; shale weathers yellow; limestone gray. Meristella piraenuntia, Tentaculites gyracanthus, Ostracoda, throughout; Rensselaeria mutabilis, 82.1................

Limestone, in four layers; blue, conchoidal, fine grained; crystalline fossiliferous streak at 80.6 ; shale laminae between layers. Meristella praenuntia, Tentaculites gyranthus, 80.6...

Shale, calcareous; light gray and yellow on weathered surface, dark gray on fresh fracture; has a diagonal "shear" parting and is interleaved with numerous thin beds of pure blue-gray crystalline limestone. Rensselaeria mutabilis (a), 78.8; Rensselaeria keyserensis, Tentaculites gyracanthus, Pelecypoda, 78.8, 77.3; Pholidops ovata, Dalmanella sp., Schuchertella prolifica, Rensselaeria (Beachia) proavita (a), Meristella sp.?, Bryozoa, 77.3......

Limestone, solid, blue, fine grained; conchoidal fracture; apparently very pure; calcite sheets at top, at base, and in middle.
Section 1 mile south of Dalmatia-Continued.

(2)

tracoda, 63.6. .

Shale, calcareous, very platy and papery; weathers yellowish and light gray; contains a number of solid but impure limestone layers (2 to 6 inches thick); shaly parts show much diagonal "shear" parting .....

Shale, calcareous, light gray, with diagonal "shear" parting............................. nodular, impure, dark gray, with several crystalline fossiliferous seams. Dalmanella concinna, Leptaena rhomboidalis, Stropheodonta bipartita, Atrypa reticularis, Ostracoda, throughout; Bryozoa, Camarotoechia sp., Spirifer vanuxemi prognosticus, Proetus sp.?, Calymene camerata, 55.1; Camarotoechia litchfieldensis, Uncinulus keyserensis?, Meristella sp., Merista typa, $52.2 \ldots \ldots . .$.

Limestone, single layer, finely crystalline, light bluish; conchoidal fracture; calcite seam at top. Meristella sp.?, 51.3..

Limestone, massive, somewhat nodular, impure, dark gray, with several crystalline fossiliferous seams. Byrozoa, Spirifer vanuxemi prognosticus, throughout; Leptaena rhomboidalis, Stropheodonta bipartita, Strophonella geniculata, Camarotoechia litchfieldensis, Pelecypoda, Ostracoda, 48.2..

Limestone, single layer, finely crystalline, light bluish; conchoidal fracture; $\frac{1}{2}$-inch calcite seam at top. Spirifer vanuxemi prognosticus, 46.9........ otal

ness.

6. 3

63.3

55.8 
Section 1 mile south of Dalmatia-Continued.

Helderberg limestone-Continued.

Keyser limestone member-Contd. Limestone, massive, dark gray, crystalline, not distinctly nodular; fossils show on weathered surface sparingly. Leptaena rhomboidalis, 45.7 . . .........

Limestone, massive, nodular, impure, dark gray, coarsely crystalline layers; calcite seams persistent parallel to bedding at $44.5,42.4$. Bryozoa, 41.6 to 44.4; Orbiculoidea sp., Spirifer vanuxemi prognosticus, Uncinulus sp., Proetus sp., 44.4; Stropheodonta bipartita, 40.6 to 44.4 ; Rensselaeria mutabilis, 44.4, 42.6; Uncinulus keyserensis, 31.7 to 42.6; Rensselaeria (Beachia) proavita, Whitfieldella cf. W. nucleolata, Meristella sp., Pelecypoda, Calymene camerata, Camarotoechia litchfieldensis, 42.6; Dalmanella cf. $D$. perelegans, 41.6; Atrypa reticularis, 38.6; Orthoceras sp., 37.1.

Limestone, massive, nodular, impure, medium gray; nodules pure, matrix impure and shaly . Favosites, in large heads, abundant in lower 7 feet; Leptaena rhomboidalis, 36.4, 34.6; Dalmanella sp., Stenoschisma deckerensis?, Atrypa reticularis (a), Rhynchospira globosa, Coelidium dalmatiae, 34.6; Favosites sp., 30.6-25.6; Dalmanella concinna, Stropheodonta bipartita, Stenoschisma formosa, Pelecypoda, 30.6; Orthoceras sp., 27.6; Schuchertella sp., Camarotoechia litchfieldensis, Spirifer modestus,

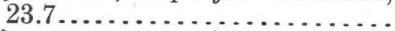

Limestone, massive, nodular, impure, much like unit above; calcite seams, 16.1, 23.6; layer of Stromatopora, 3 to 6 inches, 15.1-15.6; Dalmanella sp., Schuchertella deckerensis, Chonetes jerseyensis, Stenoschisma deckerensis, 22.6; Calymene camerata, Camarotoechia litchfieldensis, 22.6, 16.6; Spirifer modestus, 22.6 (a), 13.6?; Camarotoechia? lamellata, 1.3.618.1; Spirifer sp., 16.6; Ostracoda, 16.6, 13.6; Pelecypoda 15.6, 13.6; Spirifer vanuxemi,

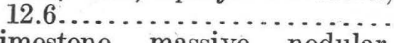

Limestone, massive, nodular, dark gray, impure; $\frac{1}{2}$-inch seam of calcite at base; when weathered looks thin bedded. Camarotoechia? lamellata, Ostracoda (c), throughout; Spirifer vanuxemi, Tentaculites gyracanthus, 8.6; Camarotoechia litchfieldensis, Spirifer modestus?, 7.6: Leperditia sp., 6.6........
Section 1 mile south of Dalmatia-Continued.

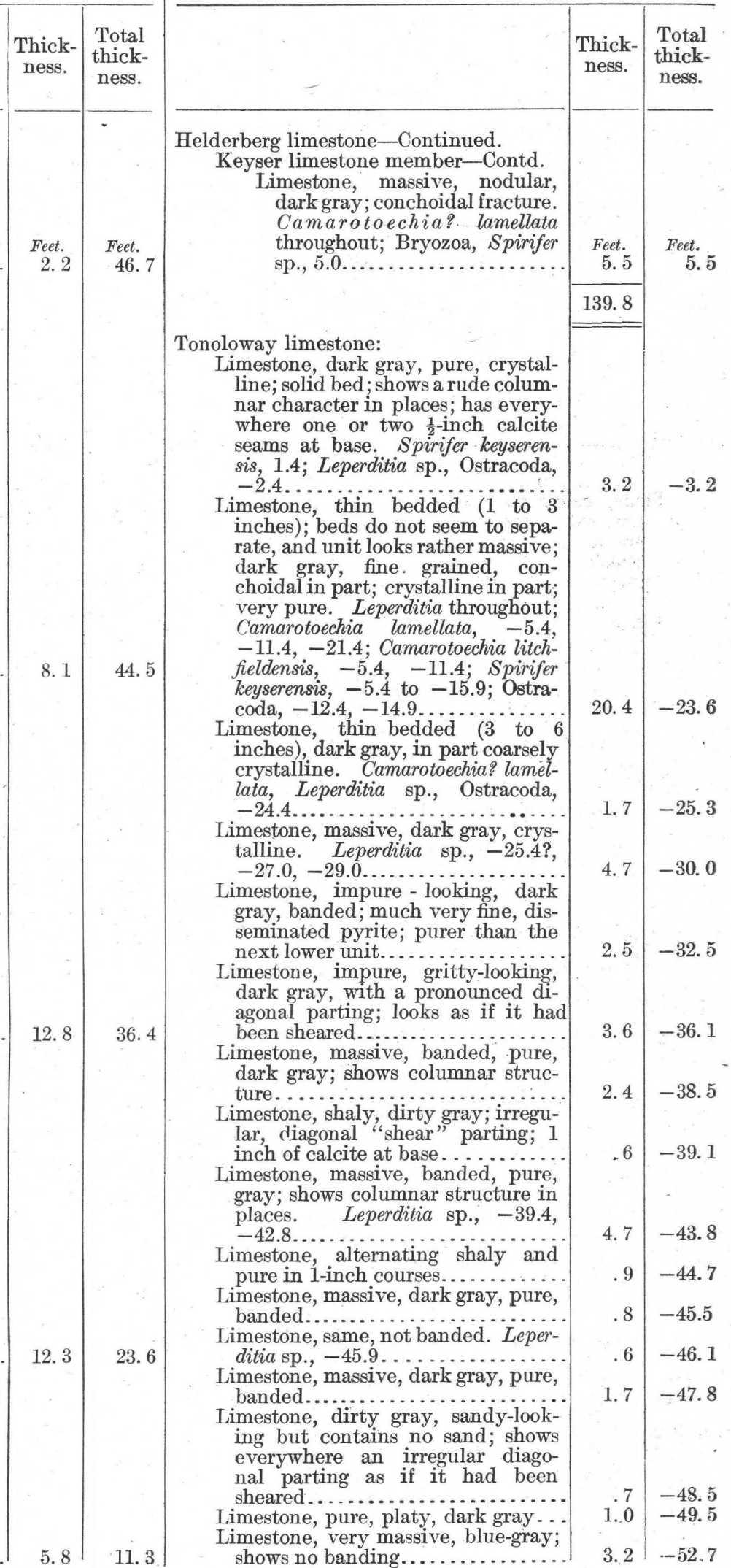


Section 1 mile south of Dalmatia-Continued.

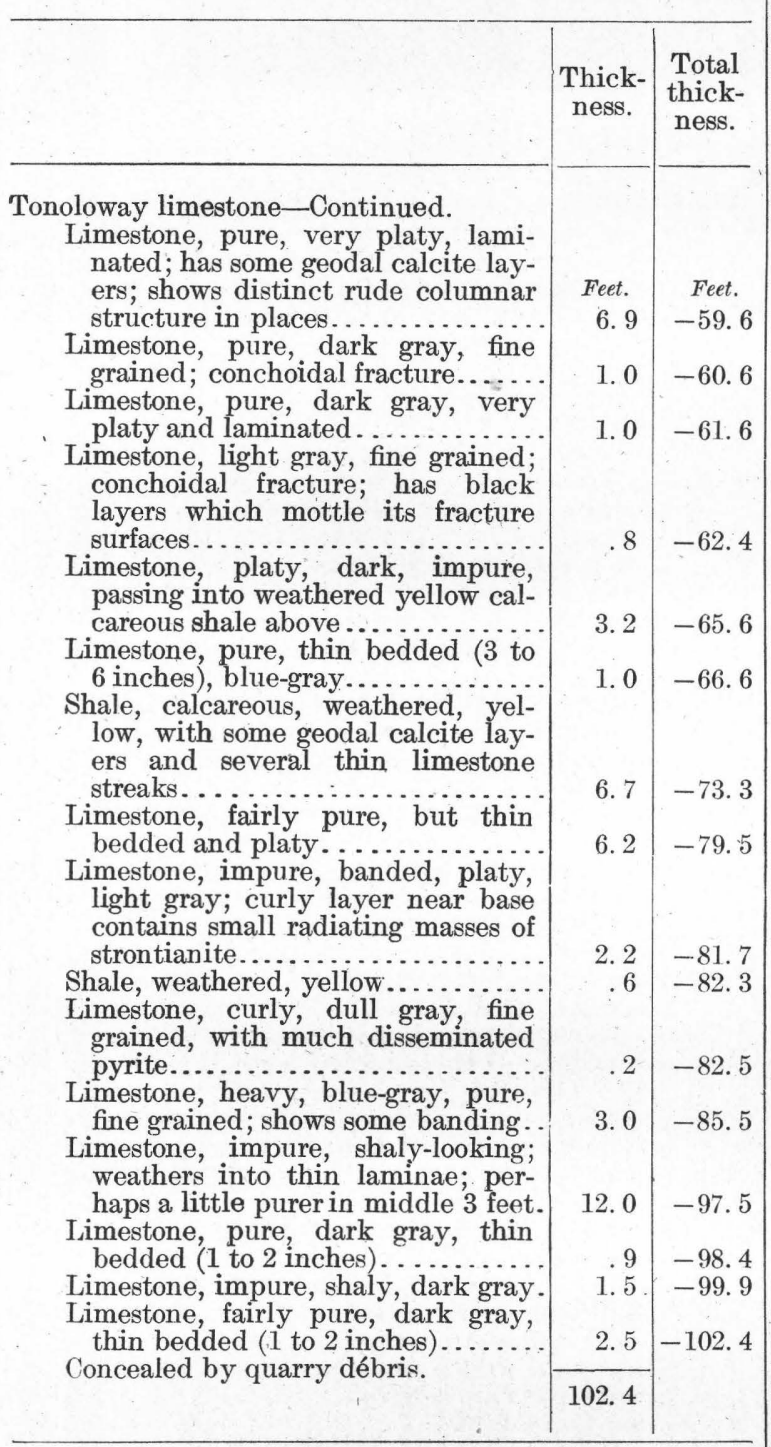

In this section the characteristic faunas of the Chonetes jerseyensis and Favosites helderbergiae var. praecedens zones are well developed, and a number of subzones are recognizable. The Tonoloway formation contains near its top the zone of Spirifer keyserensis, which is recognized at the same horizon in Maryland.

\section{SELINSGROVE JUNCTION.}

The limestone described by the Second Geological Survey of Pennsylvania as the Lewistown limestone or "Formation No. VI" is exposed along the Northern Central Railway north of Selinsgrove Junction. Susquehanna
River cuts across an anticlinal arch at this point, presenting a section which begins 1 mile above the railway station and extends approximately $1 \frac{1}{2}$ miles toward the north. Both limbs of the anticline were studied, but only the southern half is described here. The concealed unit forming the center of the arch is probably of Wills Creek age. The succeeding 148 feet of beds contain only Leperditia, rare Rhynchospira, and Ectomaria and have the characteristic lithology of the Maryland Tonoloway, with which they are probably to be correlated. The overlying beds are richly fossiliferous and embrace the Keyser, Coeymans, and New Scotland members of the Helderberg formation. These are succeeded by the Oriskany formation. No indication of the presence of the Becraft member of the Helderberg was seen. The exposures here are excellent and afford the best and most continuous section of these tormations observed by the writer.

The two sections were measured by I. C. White, ${ }^{1}$ who refers the lowest part to the Salina, and the overlying beds to the Bossardville, Bastard limestone, Stormville limestone, Stormville shales, and Oriskany. It is probable that the upper 114 feet of the Tonoloway formation described in the subjoined section represents White's Bossardville; the beds from the base of the Keyser to the base of the calcareous shales of the New Scotland represent his Bastard and Stormville limestones; and the shaly beds above the New Scotland limestone and extending up to the top of the section represent his Stormville shales. On the north side of the axis there is exposed above the horizons shown in the southern section about 25 feet of coarse cherty ferruginous sandstones, which are probably White's Oriskany beds.

The Helderbergian portion of the section was examined also by C. K. Swartz ${ }^{2}$ in 1913 . He recognized in it the equivalents of the Maryland Keyser and referred the underlying beds to the Tonoloway.

As fossils are comparatively rare in the beds lying immediately above the New Scotland limestone, the position of the New ScotlandOriskany contact is open to question. The writer places it tentatively at the base of the lowest distinctly sandy beds.

1 Pennsylvania Second Geol. Survey Rept. G7, p. 93, 1883.

${ }^{2}$ Maryland Geol. Survey, Lower Devonian, p. 108, 1913. 
Section on south side of anticlinal axis at Selinsgrove Section on south side of anticlinal axis at Selinsgrove Junction.

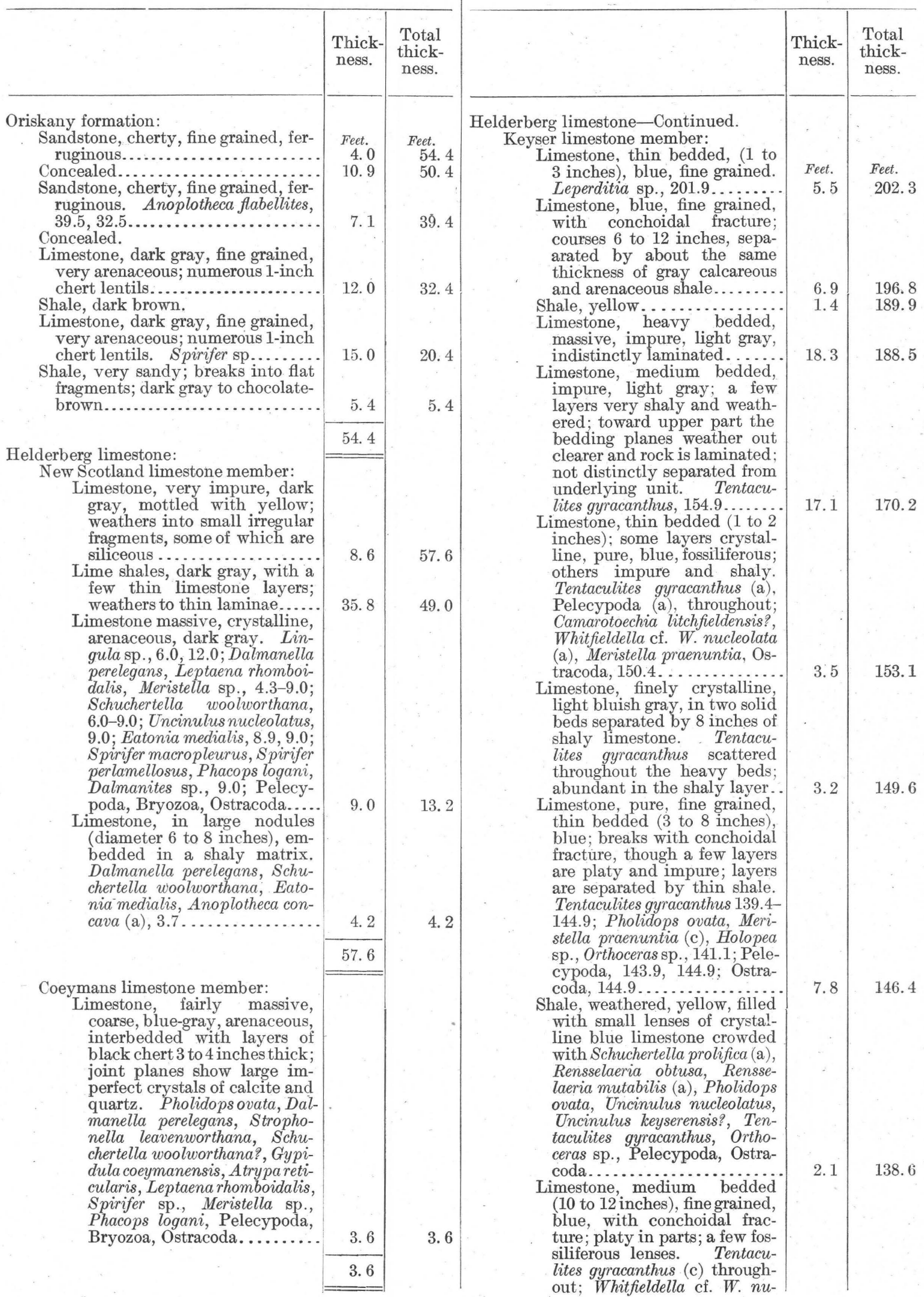


Section on south side of anticlinal axis at Selinsgrove Junction-Continued.
Section on south side of anticlinal axis at Selinsgrove Junction-Continued.

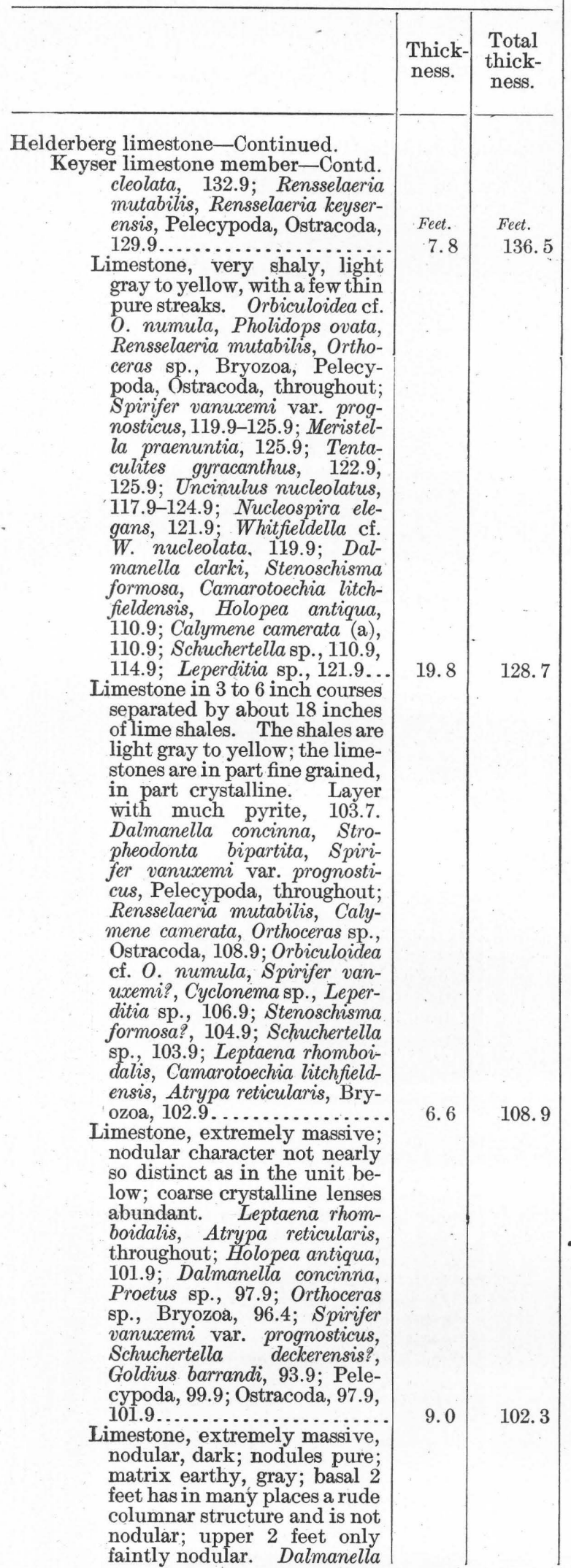

Helderberg limestone-Continued.

Keyser limestone member-Contd. concinna, Leptaena rhomboidalis, Atrypa reticularis, 88.9, 81.9; Stenochisma formosa, Camarotoechia litchfialdensis, 88.9; Chonetes jerseyensis, 87.9, 81.9; Meristella praenuntia?, 87.9; Schuchertella deckerensis, Gypidula coeymanensis var. prognostica, Stenoschisma deckerensis, Ectomaria sp., Proetus protuberans, 81.9 ; Bryozoa, 81.9-90.9; Pelecypoda,

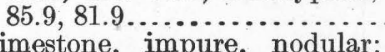

Limestone, impure, nodular; looks sandy but contains no sand......................... ded, blue-gray, with conchoidal fracture; nodular character pronounced. Stropheodonta bipartita, Schuchertella deckerensis, Chonetes jerseyensis.(c), Camarotoechia? lamellata, Atrypa recticularis, Spirifer vanuxemi, Orthoceras cf. O. perstriatum, Calymene camerata, Pelecypoda, Ostracoda, 77.9

Limestone, thin bedded, otherwise like the unit above. Camarotoechia? lamellata Calymene camerata, Orthoceras sp., Ostracoda............

Limestone, very nodular, thin bedded, fine grained, dark gray. Orthoceras sp., 70.9 ...

Limestone, very nodular, more or less impure, dark gray. $58.9-60.9,63.9-65.9)$ much more shaly than the remainder and weathers back faster. No other bedding noticeable. Ostracoda and Bryozoa, throughout; Favosites sp., 64.9, 60.9; Stenoschisma formosa, 63.9?, 60.9; Schuchertella deckerensis, $60.9,51.4$; Schuchertella interstriata?, Atrypa reticularis, Orthoceras sp., 60.9; Calymene camerata, 60.9, 54.9; Chonetes jerseyensis, $54.9,49.9$; Camarotoechia? lamellata, 54.9, 51.4; Camarotoechia litchfieldensis, 54.9, 49.9; Rhynchospira formosa, 53.9, 49.9; Rhynchospira globosa var., Dalmanella sp., 51.4; Spirifer modestus, Ectomaria minuta, 49.9; Pelecyfine grained; impure looking on fresh fracture; in places inseparable from the unit below, but apparently not a stromatoporoid bed..........

Limestone, made up entirely of stromatoporoids............... Some benches (52.9-55.9 poda, $52.9 \ldots \ldots \ldots \ldots \ldots$.

Limestone, nodular, dark gray,
Total thickness. ness. 
Section on south side of anticlinal axis at Selinsgrove Section on south side of anticlinal axis at Selinsgrove Junction-Continued.

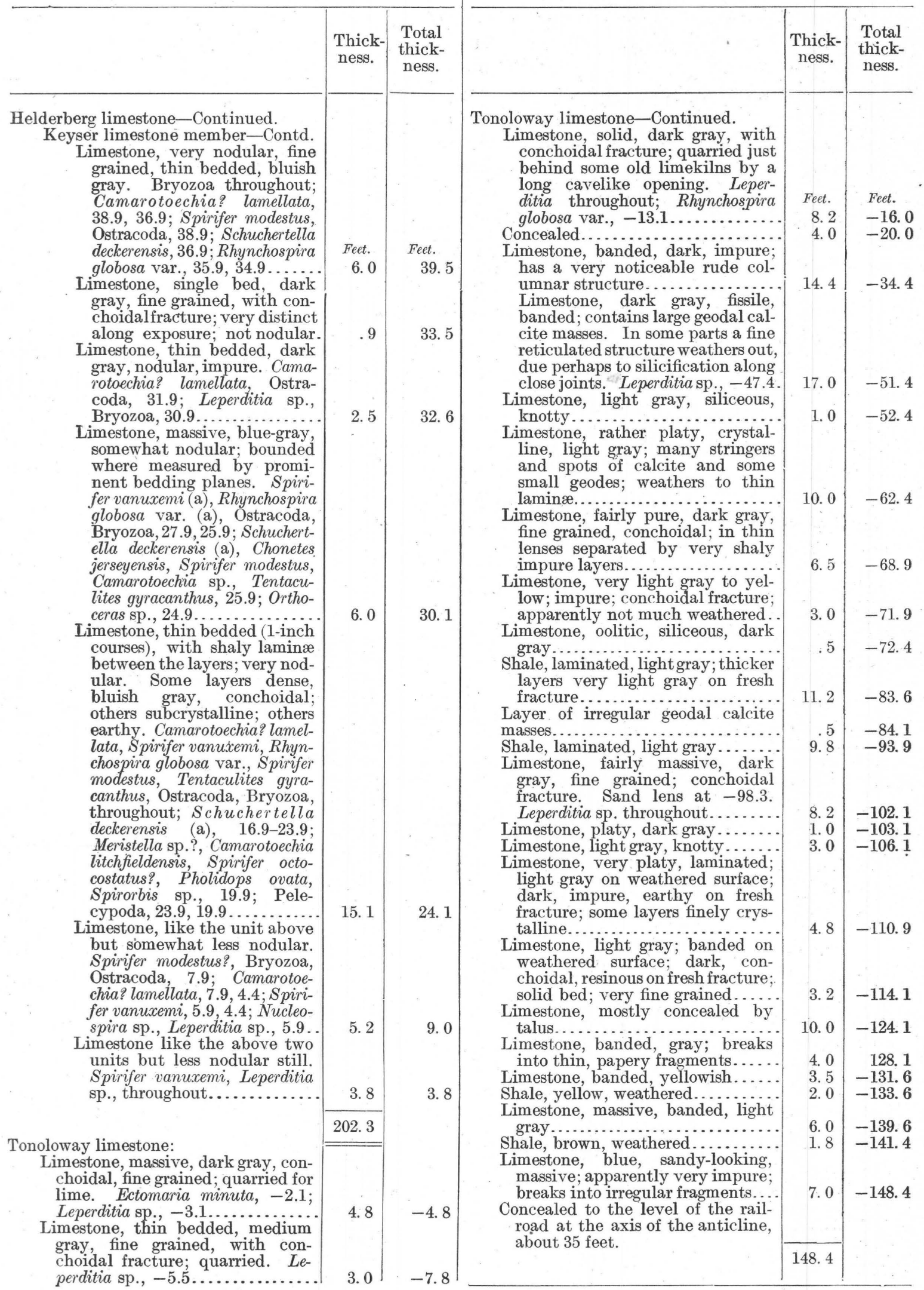


The difference between this section and that at Grovania, only 19 miles to the northeast, is striking. The total thickness of the Keyser here is 202 feet; at Grovania, 122 feet. The Chonetes zone is well developed in both, but differs greatly in thickness. The Favosites zone at Selinsgrove Junction carries an abundance of Tentaculites gyracanthus, Spirifer vanuxemi var. prognosticus, and Rensselaeria mutabilis, but has very few corals and no-stromatoporoids; the same zone at Grovania has a profusion of corals and stromatoporoids but almost none of the other forms usually common, carrying only Rensselaeria mutabilis, associated with a late form of Camarotoechia? lamellata. The Coeymans at Selinsgrove Junction is a sandy cherty limestone; at Grovania it is a dense calcareous sandstone.

\section{GROVANIA.}

The section at Grovania was measured in the quarry formerly owned by the Grove brothers, almost on the Columbia-Montour County line, about halfway between Danville and Bloomsburg. This quarry may be identified by the fact that it is the only one in the vicinity which is drained by a tunnel. The exposures are very good and include the upper 40 feet of the Tonoloway, the Keyser, the Coeymans, and, in the tunnel, about 110 feet of shale and limestone representing probably all of the New Scotland, the Becraft (if present), and perhaps part of the Oriskany.

The section was studied in 1883 by I. C. White, ${ }^{1}$ who gave a fairly detailed account of it. His description includes the following divisions: Oriskany sandstone; Stormville shale, 100 feet; Stormville conglomerate, 4 feet; Stormville limestone, 111 feet; Bastard limestone, 24 feet; Bossardvilie limestone, 105 feet. He considered these divisions equivalent to those of the same name in the counties along Delaware River. However, as the fossils cited from the Delaware River area would make his Stormville limestone in part Coeymans and in part New Scotland, and his Stormville conglomerate and shale New Scotland, the correlation is incorrect. The evidence given below demonstrates that White's Stormville conglomerate of the Grovania section is Coeymans in age; his Stormville limestone is upper Keyser; and his

\footnotetext{
1 Pennsylvania Second Geol. Survey Rept. G7, p. 88, 1883.
}

Bastard limestone is lower Keyser. The upper part of White's Bossardville is represented by the Tonoloway.

Section at Grovania.

\begin{tabular}{c}
\hline \\
Limestones and shales of undetermined \\
age, but probably New Scotland and \\
Oriskany.......................... \\
Helderberg limestone: \\
Coeymans limestone member: \\
Sandstone, coarse (grains $\frac{1}{16}$ to $\frac{1}{8}$ \\
inch in diameter), white; base \\
filled with crinoid stems and \\
other fossils; contains some \\
chert. Bryozoa, Leptaena \\
rhomboidalis, \\
leavenworthana, Strophonella \\
punctilifera, Schuchertella wool \\
worthana, Gypidula coeymanen- \\
sis (a), Atrypa reticularis, Stro- \\
pheodonta arata, Phacops logani, \\
Ostracoda, Pelecypoda, $1.0 . .$.
\end{tabular}

Keyser limestone member:

Limestone, irregular, crinoidal, dark blue.................

Limestone, compact, light blue, heavy bedded; conchoidal fracture ....................

Limestone, laminated, light gray to yellowish, platy. Has some solid 6 -inch layers of light-gray rock, but for the most part is rather shaly. Barren of fossils.

Limestone; a peculiar pebbly stromatoporoid makes up whole of rock......................

Limestone, blue, pure, with many transverse calcite seams massive and somewhat nodular; composed almost entirely of stromatoporoids; has $\frac{1}{2}$-inch layer of shale at top...........

Shale, yellow....................

Limestone, composed almost en-
tirely of stromatoporoids.......

Shale, blue-black, with one or two limestone layers. Limestone at 65.1 is arenaceous. Camarotoechia? lamellata, 65.1, 63.1 (a); Rensselaeria mutabilis (a), 65.1; Atrypa rugosa? , 63.1, 62.1; Favosites sp., Spirorbis laxus; Pholidops ovata (c), Schuchertellasp.?,Camarotoechia litchfieldensis?, Rensselaeria keyserensis (a), Spirifer vanuxemi prognosticus, Whitfieldella cf. W. nucleolata, Ostracoda (a),

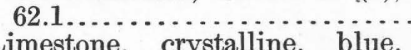
Limestone, crystalline, blue,
pure. Favosites sp............ Limestone, crystalline, blue, pure; many transverse calcite seams.....................

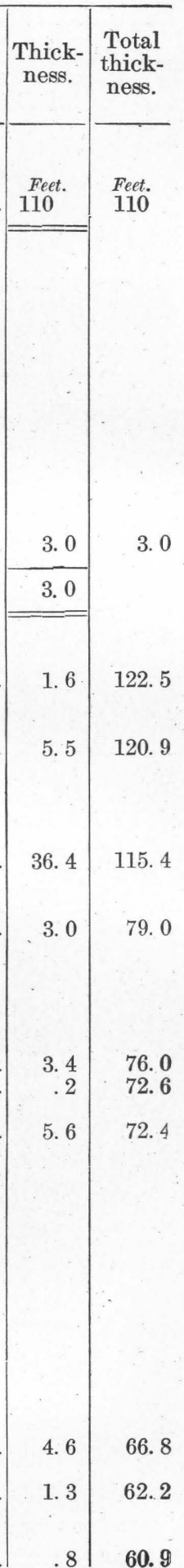

60.9 
Section at Grovania - Continued.

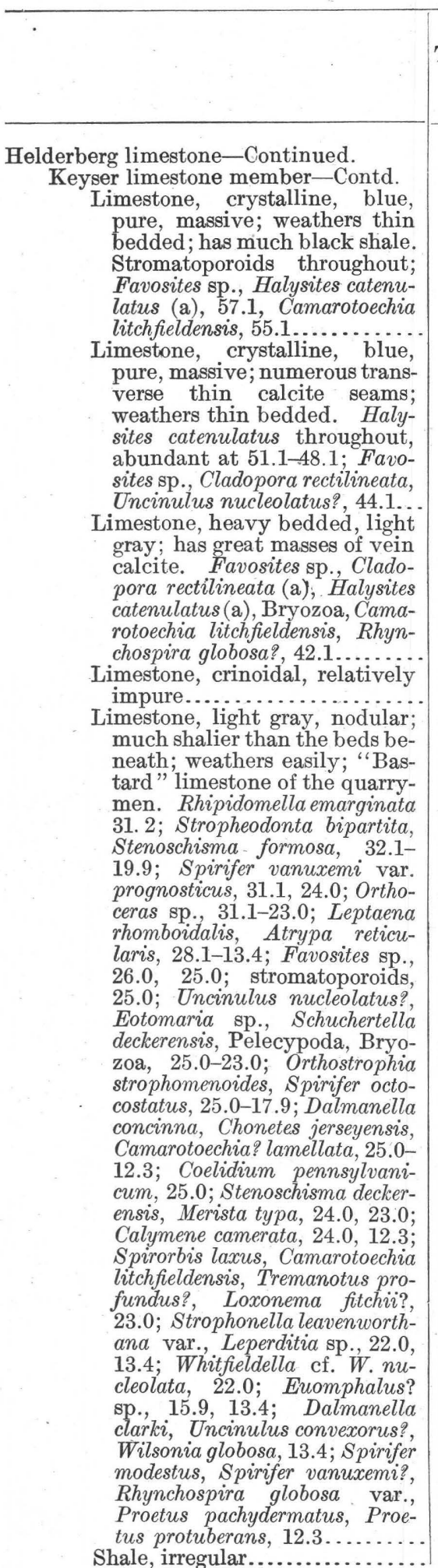

Section at Grovania-Continued.

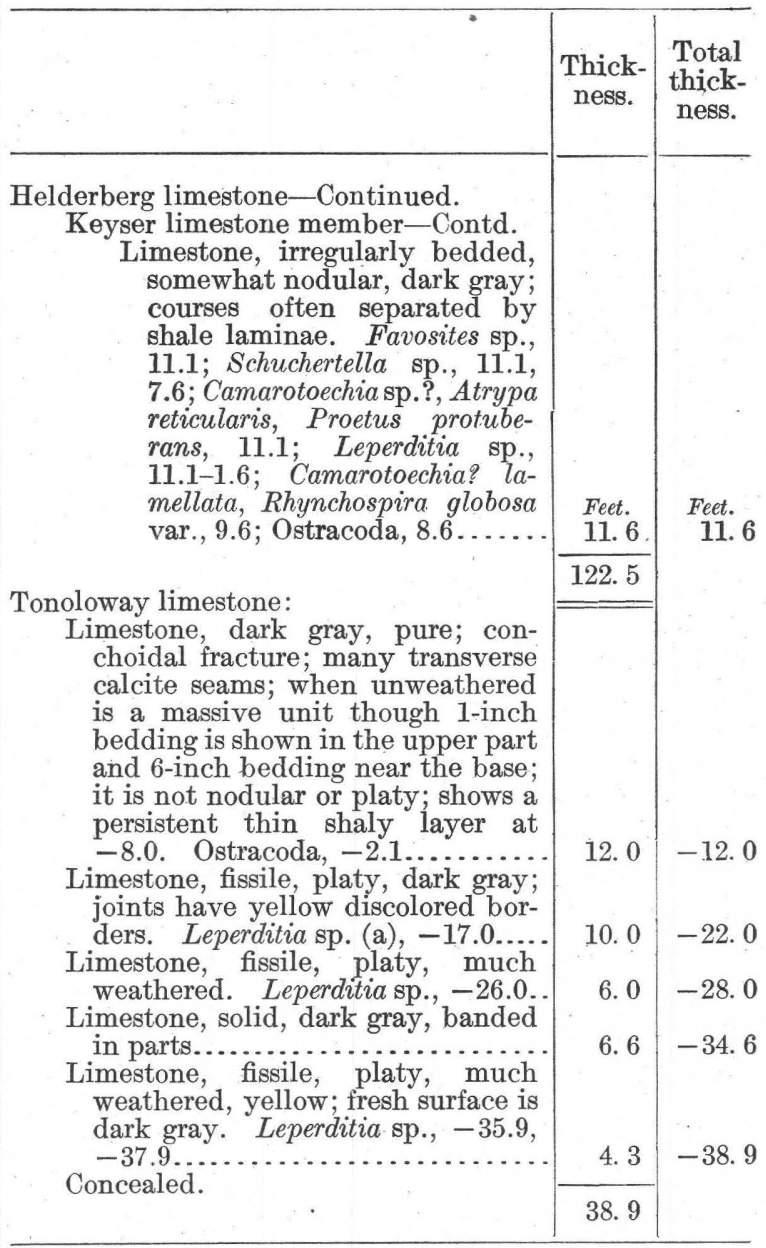

The Grovania section resembles the Tyrone sections very closely, but differs from all the others studied in Pennsylvania and from the Maryland sections. The Tonoloway is identical in lithology with that in the other sections, though its fauna, so far as it is known, includes only ostracodes. The Chonetes jerseyensis zone of the Keyser is well developed and carries a characteristic fauna. The Favosites helderbergiae var. praecedens zone of the Keyser is peculiar in that its lower part is made up of thick beds of coralline limestone and stromatoporoids. - It has also a thin zone of Rensselaeria mutabilis, but it lacks most of the other characteristic brachiopods of the upper Keyser and contains no Tentaculites gyracanthus. The Coeymans is here a sandstone, as it is in the 11. 9 easternmost Maryland sections. 